\title{
Photoinduced Diverse Reactivity of Diazo Compounds with Nitrosoarenes
}

Sourav Roy, ${ }^{a}$ Gourav Kumar ${ }^{\mathrm{a}}$ and Indranil Chatterjee ${ }^{\mathrm{a} *}$

\author{
Indian Institute of Technology Ropar \\ Ropar, Punjab-140001, India \\ indranil.chatterjee@iitrpr.ac.in
}

Supplementary Information 


\section{Table of Contents}

1. General Information. $\quad$ S4

2. Photoreactor Setup. $\quad$ S4

3. List of substrates prepared.

3.1. List of diazo compounds prepared. $\quad$ S5

3.2. List of nitrosoarenes prepared. $\quad$ S5

4. Optimization Table. S6

4.1. Table 1: Miscellaneous Optimization 1. S6

$\begin{array}{lr}\text { 4.2. Table 2: Screening of Solvents. } & \text { S7 }\end{array}$

4.3. Table 3: Screening of Different Light Source. $\quad$ S7

4.4. Table 4: Screening of Nitrosoarenes. $\quad$ S8

4.5. Oxygen transfer agents other than nitrosoarenes $\quad$ S8

4.5. Table 5: Miscellaneous Optimization $2 . \quad$ S9

5. General procedures. $\quad \mathrm{S} 10$

5.1. General procedure for preparation of $\alpha$-diazoesters (GP-1). $\quad \mathrm{S} 10$

5.2. General procedure for preparation of $\alpha$-diazoesters (GP-2). $\quad S 10$

5.3. General procedure for preparation of $\alpha$-diazoesters (GP-3). $\quad$ S11

5.4. General procedure for preparation of ethyl 2-diazo-2-(thiophen-2-yl)acetate (GP-4). $\quad$ S11

5.5. General procedure for preparation of tert-butyl 3-(1-diazo-2-methoxy-2-oxoethyl)-1H-indole-1-carboxylate

$\begin{array}{ll}\text { (GP-5). } & \text { S11 }\end{array}$

5.6. General procedure for preparation of $\alpha$-diazo- $\beta$-keto esters (GP-6). $\quad$ S12

5.7. General procedure for preparation of diazoacetophenone (GP-7). $\quad$ S13

5.8. General procedure for preparation of $\alpha$-diazoketones (GP-8). $\quad$ S13

5.9. General procedure for preparation of $\alpha$-aryldiazoketone (GP-9). $\quad$ S14

5.10. General procedure for the preparation of oxoacetate derivatives (GP-10). $\quad$ S14

5.11. General procedure for the preparation of oxazetidine derivatives (GP-11). $\quad$ S14

5.12. General procedure for the reduction of oxazetidine derivative to prepare 6a (GP-12). $\quad \mathrm{S} 15$

5.13. General procedure for the reduction of oxazetidine derivative to prepare $6 \mathrm{~b}$ (GP-13). $\quad \mathrm{S} 15$

5.14. General procedure for the reduction of oxazetidine derivative to prepare 6c (GP-14) S16

$\begin{array}{ll}\text { 6. Control Experiments and UV-Visible spectra } & \text { S17 }\end{array}$

6.1. Control Experiments $\quad$ S17

$\begin{array}{ll}\text { 6.2. UV-Visible spectra } & \text { S17 }\end{array}$

7. Plausible Mechanism \& Synthetic Applications $\quad$ S18

$\begin{array}{ll}\text { 7.1. Plausible Mechanism } & \text { S18 }\end{array}$

7.2. $N$-(2-methoxy-2-oxo-1-phenylethylidene)aniline oxide (3a') $\quad$ S18

7.3. (E)-ethyl 2-phenyl-2-(phenylimino)acetate (IXa) S20 
Supplementary Information

7.4. Synthetic Applications $\quad$ S22

8. References $\quad$ S23

9. Result \& Characterization. $\quad$ S24

9.1. methyl 2-oxo-2-phenylacetate (3a) $\quad$ S24

9.2. methyl 2-(4-methoxyphenyl)-2-oxoacetate (3b) $\quad$ S24

9.3. methyl 2-(4-fluorophenyl)-2-oxoacetate (3c) $\quad$ S24

9.4. methyl 2-(4-chlorophenyl)-2-oxoacetate (3d) $\quad$ S25

9.5. methyl 2-(2-bromophenyl)-2-oxoacetate (3e) $\quad$ S25

9.6. methyl 2-(naphthalen-2-yl)-2-oxoacetate (3f) S26

9.7. ethyl 2-oxo-2-phenylacetate (3g) $\quad$ S26

$\begin{array}{ll}\text { 9.8. ethyl 2-oxo-2-(o-tolyl)acetate (3h) } & \text { S27 }\end{array}$

$\begin{array}{ll}\text { 9.9. isopropyl 2-oxo-2-phenylacetate (3i) } & \text { S27 }\end{array}$

$\begin{array}{lll}9.10 . & \text { benzyl 2-oxo-2-phenylacetate (3j) } & \text { S28 }\end{array}$

9.11. allyl 2-oxo-2-phenylacetate (3k) S28

9.12. prop-2-yn-1-yl 2-oxo-2-phenylacetate (31) S29

9.13. $\quad(1 R, 2 S, 5 R)$-2-isopropyl-5-methylcyclohexyl 2-oxo-2-phenylacetate (3m) S29

9.14. ethyl 2-oxo-2-(thiophen-2-yl)acetate (3n) S30

9.15. tert-butyl 3-(2-methoxy-2-oxoacetyl)- $1 H$-indole-1-carboxylate (3o) S30

9.16. ethyl 3-oxo-2,4-diphenyl-1,2-oxazetidine-4-carboxylate (5a) S30

9.17. ethyl 3-oxo-2-phenyl-4-( $p$-tolyl)-1,2-oxazetidine-4-carboxylate (5b) S31

9.18. ethyl 4-(4-fluorophenyl)-3-oxo-2-phenyl-1,2-oxazetidine-4-carboxylate (5c) S31

9.19. ethyl 4-(4-bromophenyl)-3-oxo-2-phenyl-1,2-oxazetidine-4-carboxylate (5d) S32

9.20. ethyl 3-oxo-4-phenyl-2-(2-(trifluoromethyl)phenyl)-1,2-oxazetidine-4-carboxylate (5e) S33

9.21. ethyl 2-(2-cyanophenyl)-3-oxo-4-phenyl-1,2-oxazetidine-4-carboxylate (5f) $\quad$ S33

9.22. 2,4-diphenyl-1,2-oxazetidin-3-one $(5 \mathrm{~g})$ : $\quad \mathrm{S} 34$

9.23. phenyl-4-(p-tolyl)-1,2-oxazetidin-3-one (5h) S34

9.24. 4-methyl-2,4-diphenyl-1,2-oxazetidin-3-one (5i)

9.25. methyl 3-oxo-2-phenyl-4-(thiophen-2-yl)-1,2-oxazetidine-4-carboxylate (5j): $\quad$ S35

9.26. ethyl 3-hydroxy-2-phenyl-2-((phenylamino)oxy)propanoate (6a) S36

9.27. 2-phenyl-2-((phenylamino)oxy)propane-1,3-diol (6b) S36

9.28. ethyl 2-hydroxy-3-oxo-2-phenyl-3-(phenylamino)propanoate (6c): $\quad$ S37

10. NMR Spectra. $\quad$ S38 


\section{Supplementary Information}

\section{General Information:}

All reactions were performed in flame-dried glassware under argon atmosphere unless otherwise stated. Liquids and solutions were transferred with syringes. Solvents used were dried and purified by following standard procedures. Technical grade solvents for extraction or chromatography (ethyl acetate, and petroleum ether) were distilled prior to use. $\mathrm{CDCl}_{3}$ was stored over $4 \AA$ molecular sieves. Used chemicals were purchased from Sigma-Aldrich, TCI, Alfa-Aesar and Sisco Research Laboratories (SRL) used without further purification. All the liquid chemicals distilled freshly prior to use. Analytical thin-layer chromatography (TLC) was performed on using pre-coated aluminium-backed plates (Merck Kieselgel 60 F254) and visualized by UV radiation, basic aqueous potassium permangante $\left(\mathrm{KMnO}_{4}\right), p$-anisaldehyde stains and heat as developing agents.

Flash column chromatography was performed on silica gel $60(40-63 \mu \mathrm{m}, 230-400$ mesh, ASTM) from Merck using the indicated solvents. Organic solutions were concentrated under reduced pressure on Heidolph rotary evaporator. NMR spectra were acquired on a JEOL JNM ECS-400, JEOL JNM ECS-500, Bruker AVANCE NEO $400 \mathrm{MHz}$ FT-NMR and Bruker AVANCE NEO $500 \mathrm{MHz}$ FT-NMR instrument running at $400 \mathrm{MHz}$ for ${ }^{1} \mathrm{H}, 101$ $\mathrm{MHz}{ }^{13} \mathrm{C}$ and $376 \mathrm{MHz}$ for ${ }^{19} \mathrm{~F}$ and at $500 \mathrm{MHz}$ for ${ }^{1} \mathrm{H}, 126 \mathrm{MHz}{ }^{13} \mathrm{C}$ and $470 \mathrm{MHz}$ for ${ }^{19} \mathrm{~F}$ respectively. Chemical shifts $(\delta)$ are reported in ppm relative to residual solvent signals $\left(\mathrm{CHCl}_{3}, 7.26 \mathrm{ppm}\right.$ for ${ }^{1} \mathrm{H} \mathrm{NMR}, \mathrm{CDCl}_{3}, 77.0 \mathrm{ppm}$ for ${ }^{13} \mathrm{C}$ NMR). Data are reported as follows: chemical shift, multiplicity ( $\mathrm{br}=$ broad singlet, $\mathrm{s}=$ singlet, $\mathrm{d}=$ doublet, $\mathrm{dd}=$ doublet of doublets, $\mathrm{t}=$ triplet, $\mathrm{q}=$ quartet, $\mathrm{ddd}=$ doublet of doublet of doublet, $\mathrm{td}=$ triplet of doublet, $\mathrm{m}=$ multiplet), coupling constants $(\mathrm{Hz})$, and integration. 1,2-Dibromomethane was used as an internal standard to calculate NMR yields of products by ${ }^{1} \mathrm{H}$ NMR analysis of the crude mixture.

\section{Photoreactor Setup:}

Photochemical reactions were carried out in $5 \mathrm{ml}$ bottom plane borosilicate glass vials in a Penn Phd Photoreactor $\mathrm{m} 2$ composed of cooling block and LED plate connected to AC/DC input $100-240 \mathrm{~V} \mathrm{AC}, 50 / 60 \mathrm{~Hz}$ power supply (Figure 1). The instrument details are given by the manufacturer as follows-

AC/DC input 100 - $240 \mathrm{~V} \mathrm{AC,} \mathrm{50/60} \mathrm{Hz;} \mathrm{feature} \mathrm{thermocouple} \mathrm{type} \mathrm{K-Type} \mathrm{Thermocouple} \mathrm{(Touch} \mathrm{Screen:} \mathrm{3.5"}$ TFT LCD; 320 x 480 resolution); reaction suitability reaction type: Photocatalysis reagent type: catalyst parameter (Variable stir bar control $100-2000 \mathrm{RPM}$ ) $0-95 \% \mathrm{RH}$ at $10-40{ }^{\circ} \mathrm{C} ; \mathrm{W} \times \mathrm{H} \times \mathrm{D} 11.4 \mathrm{~cm} \times 27.2 \mathrm{~cm} \times 27.9 \mathrm{~cm} 4.5 \mathrm{in}$. $\times 10.7$ in. $\times 11.0$ in. Filters used- $450 \mathrm{~nm}, 420 \mathrm{~nm}$, and $365 \mathrm{~nm}$.

Instrument details available at: https://www.pennphd.com/product/5

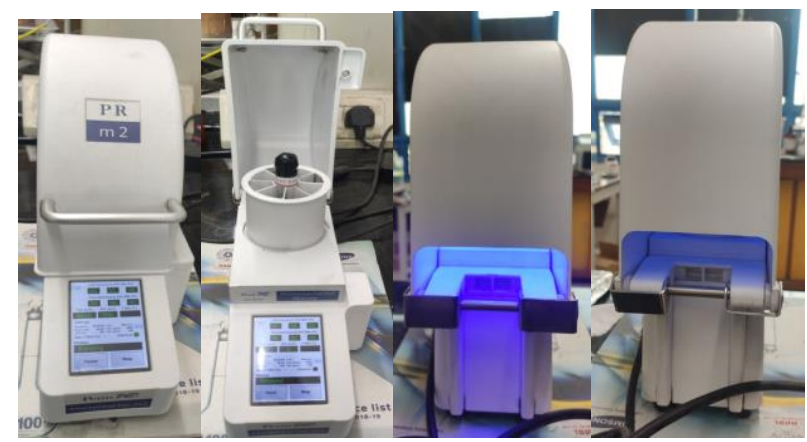

Figure S1: Photochemical reaction set up. 
Supplementary Information

\section{List of substrates prepared:}

3.1. List of diazo compounds prepared: ${ }^{\mathrm{S} 1-\mathrm{S} 10}$

The lists of substrates prepared according to GP-1-GP-7 are given bellow.

\section{List of diazo compounds}
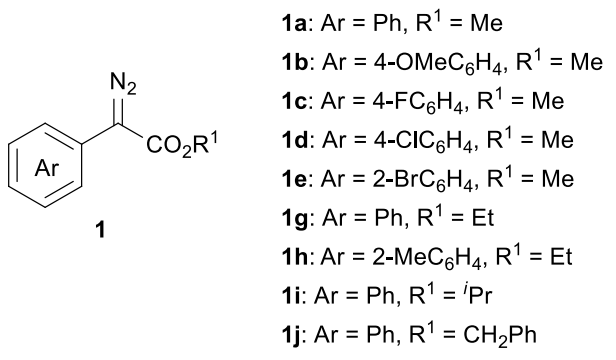

1i: $\mathrm{Ar}=\mathrm{Ph}, \mathrm{R}^{1}={ }^{i} \mathrm{Pr}$

$1 \mathrm{j}: \mathrm{Ar}=\mathrm{Ph}, \mathrm{R}^{1}=\mathrm{CH}_{2} \mathrm{Ph}$

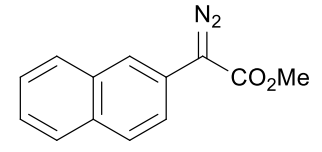

$1 f$<smiles>C=CCOC(=O)C(=N)c1ccccc1</smiles>

$1 k$<smiles>C#CCOC(=O)C(=N)c1ccccc1</smiles>

11<smiles>[R]C(=O)C(=[W])C(=O)c1ccccc1</smiles>

4<smiles>CC(C)[C@H]1CC[C@@H](C)C[C@H]1OC(=O)C(=N)c1ccccc1</smiles>

$1 \mathrm{~m}$

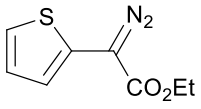

$1 n$<smiles>CC(=O)C(=N)c1cn(C(C)=O)c2ccccc12</smiles>

10

4a: $\mathrm{Ar}=\mathrm{Ph}, \mathrm{R}^{2}=\mathrm{OEt}$

4b: $\mathrm{Ar}=4-\mathrm{MeC}_{6} \mathrm{H}_{4}, \mathrm{R}^{2}=\mathrm{OEt}$

4c: $\mathrm{Ar}=4-\mathrm{FC}_{6} \mathrm{H}_{4}, \mathrm{R}^{2}=\mathrm{OEt}$

4d: $\mathrm{Ar}=4-\mathrm{BrC}_{6} \mathrm{H}_{4}, \mathrm{R}^{2}=\mathrm{OEt}$

4f: $\mathrm{Ar}=\mathrm{Ph}, \mathrm{R}^{2}=\mathrm{Me}$

4g: $\mathrm{Ar}=4-\mathrm{MeC}_{6} \mathrm{H}_{4}, \mathrm{R}^{2}=\mathrm{Me}$

4k: $\mathrm{Ar}=2$-thienyl, $\mathrm{R}^{2}=\mathrm{OMe}$<smiles>N=CC(=O)c1ccccc1</smiles>

$4 e$<smiles>CC(=O)C(=N)c1ccccc1</smiles>

4h

\section{List of unsuccessful diazo compound}<smiles>CCOC(=N)c1ccccc1C(=O)OCC</smiles>

$1 p$<smiles>CC(=O)C(=N)/C=C/Cc1ccccc1</smiles>

$1 \mathrm{q}$<smiles>CCOC(=N)C(=N)OCC</smiles>

4h<smiles>CCOC(=O)C(C)=O</smiles>

$4 i$<smiles>CC1(C)OC(=O)C(=N)C(=O)O1</smiles>

4j

3.2. List of nitrosoarenes prepared:

All nitrosoarenes were prepared according to the previous literatures. ${ }^{\text {S11-S18 }}$

\section{List of Nitrosoarenes}<smiles>O=[N+]([O-])c1ccccc1</smiles>

$2 \mathbf{a}$

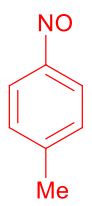

$2 \mathbf{b}$<smiles>Cc1ccc([N+](=O)[O-])c(C)c1</smiles>

2c<smiles>COc1ccc([N+](=O)[O-])cc1</smiles>

2d<smiles>O=[N+]([O-])c1ccc(Br)cc1</smiles>

$2 e$<smiles>O=[N+]([O-])c1ccccc1C(F)(F)F</smiles>

$2 f$<smiles>N#Cc1ccccc1[N+](=O)[O-]</smiles>

$2 \mathrm{~g}$ 


\section{Optimization Table:}

\subsection{Table S1: Miscellaneous Optimization $1^{[a]}$}

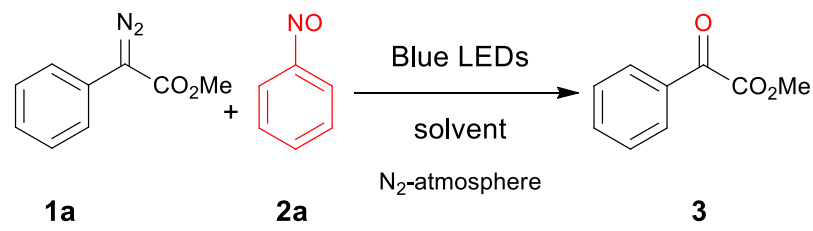

\begin{tabular}{ccccccc|}
\hline \hline Entry & $1 \mathbf{a}$ & $\mathbf{2 a}$ & Solvent (M) & Time (h) & Temp. $\left({ }^{\circ} \mathrm{C}\right)$ & Yield (\%) ${ }^{[\mathrm{b}]}$ \\
\hline 1 & 1 & 1 & $\operatorname{DCM}(0.1)$ & 3 & 45 & 31 \\
2 & 1 & 1 & $\operatorname{DCM}(0.1)$ & 5 & 45 & 33 \\
3 & 1 & 1 & $\operatorname{DCM}(0.1)$ & 10 & 45 & 42 \\
4 & 1 & 1 & $\operatorname{DCM}(0.1)$ & 10 & 0 & 49 \\
5 & 1 & 1 & $\operatorname{DCM}(0.1)$ & 10 & -20 & 37 \\
6 & 1 & 1 & $\operatorname{DCM}(0.1)$ & 10 & $\mathrm{rt}$ & 47 \\
7 & 1 & 1.5 & $\operatorname{DCM}(0.1)$ & 10 & $\mathrm{rt}$ & 34 \\
8 & 1.5 & 1 & $\operatorname{DCM}(0.1)$ & 10 & $\mathrm{rt}$ & 68 \\
9 & 2 & 1 & $\operatorname{DCM}(0.1)$ & 10 & $\mathrm{rt}$ & 74 \\
10 & 2 & $\mathbf{1}$ & $\operatorname{DCM}(0.2)$ & 10 & $\mathrm{rt}$ & $\mathbf{8 1}(\mathbf{7 6})$ \\
11 & 1 & 0 & $\operatorname{DCM}(0.1)$ & 10 & $\mathrm{rt}$ & 8 \\
$12^{\mathrm{c}}$ & 1 & 0 & $\operatorname{DCM}(0.2)$ & 10 & $\mathrm{rt}$ & 10 \\
$13^{\mathrm{c}}$ & 2 & 1 & $\operatorname{DCM}(0.2)$ & 10 & $\mathrm{rt}$ & 72 \\
\hline
\end{tabular}

[a] unless untill mentioned all reactions were carried out in $0.1 \mathrm{mmol}$ scale in dry DCM. [b] yield was measured by ${ }^{1} \mathrm{H}-\mathrm{NMR}$ analysis of the crude reaction mixture using $\mathrm{CH}_{2} \mathrm{Br}_{2}$ as an internal standard, isolated yield in parentheses. [c] reaction was carried out under $\mathrm{O}_{2}$ atmosphere. 


\subsection{Table S2: Screening of Solvents ${ }^{[a]}$}

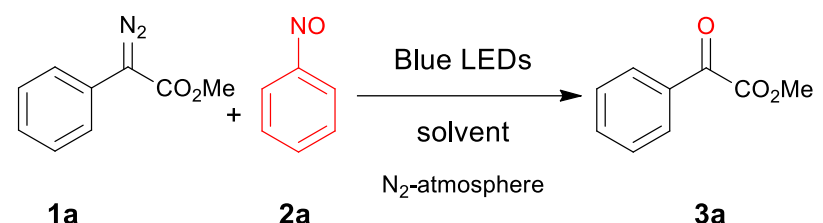

\begin{tabular}{|c|c|c|c|c|}
\hline Entry & Solvent (M) & Time (h) & Temp. $\left({ }^{\circ} \mathrm{C}\right)$ & Yield $(\%)^{[b]}$ \\
\hline 1 & DCM (0.2) & 10 & rt & $81(76)$ \\
\hline 2 & $\mathrm{CHCl}_{3}(0.2)$ & 10 & $\mathrm{rt}$ & 46 \\
\hline 3 & $\mathrm{Et}_{2} \mathrm{O}(0.2)$ & 10 & $\mathrm{rt}$ & 75 \\
\hline 4 & $\mathrm{CH}_{3} \mathrm{CN}(0.2)$ & 10 & $\mathrm{rt}$ & 57 \\
\hline 5 & DCE $(0.2)$ & 10 & $\mathrm{rt}$ & 77 \\
\hline 6 & THF (0.2) & 10 & $\mathrm{rt}$ & 64 \\
\hline 7 & benzene $(0.2)$ & 10 & $\mathrm{rt}$ & 73 \\
\hline 8 & toluene $(0.2)$ & 10 & $\mathrm{rt}$ & 75 \\
\hline 9 & DMSO (0.2) & 10 & $\mathrm{rt}$ & 32 \\
\hline 10 & $\mathrm{EtOH}(0.2)$ & 10 & $\mathrm{rt}$ & 17 \\
\hline $11^{\mathrm{c}}$ & DMSO $(0.2)$ & 10 & $\mathrm{rt}$ & 20 \\
\hline
\end{tabular}

[a] unless untill mentioned all reactions were carried out in $0.1 \mathrm{mmol}$ scale by taking 1a ( 2.0 equiv) \& $\mathbf{2 a}$ (1.0 equiv) in respective dry solvents. [b] yield was measured by ${ }^{1} \mathrm{H}-\mathrm{NMR}$ analysis of the crude reaction mixture using $\mathrm{CH}_{2} \mathrm{Br}_{2}$ as an internal standard, isolated yield in parentheses. [c] Reaction was carried out in absence of $\mathbf{2 a}$.

\subsection{Table S3: Screening of Different Light Source ${ }^{[a]}$}




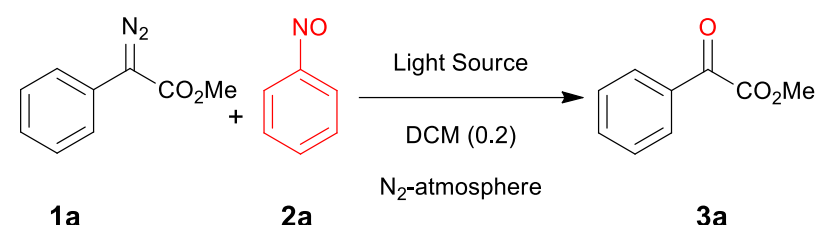

\begin{tabular}{|ccccc|}
\hline \hline Entry & Light Source & Time (h) & Temp. $\left({ }^{\circ} \mathrm{C}\right)$ & Yield (\%) ${ }^{[\mathrm{b}]}$ \\
\hline $\mathbf{1}$ & Blue LEDs $(\mathbf{4 5 0} \mathrm{nm})$ & $\mathbf{1 0}$ & $\mathrm{rt}$ & $\mathbf{8 1}(\mathbf{7 6})$ \\
2 & Blue LEDs $(420 \mathrm{~nm})$ & 10 & $\mathrm{rt}$ & 56 \\
3 & White LEDs & 10 & $\mathrm{rt}$ & 52 \\
4 & UV LEDs & 10 & $\mathrm{rt}$ & 37 \\
5 & Blue LEDs (strip) & 10 & $\mathrm{rt}$ & 31 \\
6 & Green LEDs (strip) & 10 & $\mathrm{rt}$ & 15 \\
7 & in dark & 10 & $\mathrm{rt}$ & 0 \\
\hline
\end{tabular}

[a] unless untill mentioned all reactions were carried out in $0.1 \mathrm{mmol}$ scale by taking $1 \mathbf{a}$ (2.0 equiv) \& $\mathbf{2 a}(1.0$ equiv) in dry DCM. [b] yield was measured by ${ }^{1} \mathrm{H}-\mathrm{NMR}$ analysis of the crude reaction mixture using $\mathrm{CH}_{2} \mathrm{Br}_{2}$ as an internal standard, isolated yield in parentheses.

\subsection{Table S4: Screening of Nitrosoarenes ${ }^{[a]}$}

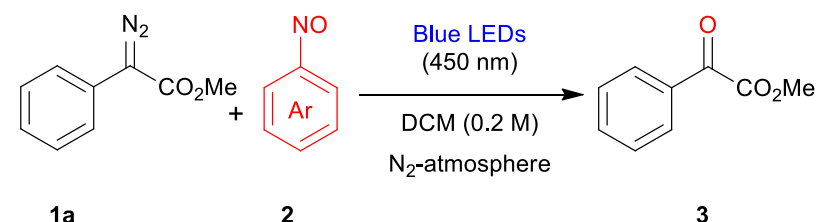

\begin{tabular}{|ccccc|}
\hline \hline Entry & Nitrosoarene (2) & Time (h) & Temp. $\left({ }^{\circ} \mathrm{C}\right)$ & Yield (\%) ${ }^{[\mathrm{b}]}$ \\
\hline \hline $\mathbf{1}$ & 2a & $\mathbf{1 0}$ & $\mathrm{rt}$ & $\mathbf{8 1}(\mathbf{7 6})$ \\
2 & $2 \mathrm{~b}$ & 10 & $\mathrm{rt}$ & 51 \\
3 & $2 \mathrm{c}$ & 10 & $\mathrm{rt}$ & 49 \\
4 & $2 \mathrm{~d}$ & 10 & $\mathrm{rt}$ & 42 \\
5 & $2 \mathrm{e}$ & 10 & $\mathrm{rt}$ & 55 \\
6 & $2 \mathrm{f}$ & 10 & $\mathrm{rt}$ & 57 \\
\hline
\end{tabular}

[a] unless untill mentioned all reactions were carried out in $0.1 \mathrm{mmol}$ scale by taking 1a (2.0 equiv) \& 2 (1.0 equiv) in dry DCM. [b] yield was measured by ${ }^{1} \mathrm{H}-\mathrm{NMR}$ analysis of the crude reaction mixture using $\mathrm{CH}_{2} \mathrm{Br}_{2}$ as an internal standard, isolated yield in parentheses. 
4.6. Table S6: Miscellaneous Optimization $2^{[a]}$

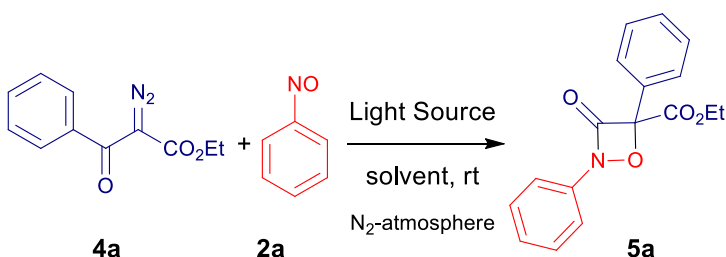

\begin{tabular}{|c|c|c|c|c|c|c|}
\hline Entry & $1 a$ & $2 a$ & Solvent (M) & Time (h) & $\begin{array}{l}\text { Light source } \\
\text { (LEDs) }\end{array}$ & Yield $(\%)^{[\mathrm{b}]}$ \\
\hline 1 & 2 & 1 & $\operatorname{DCM}(0.2)$ & 10 & $450 \mathrm{~nm}$ & 0 \\
\hline 2 & 2 & 1 & $\mathrm{DCM}(0.2)$ & 10 & $420 \mathrm{~nm}$ & 0 \\
\hline 3 & 2 & 1 & $\mathrm{DCM}(0.2)$ & 10 & $365 \mathrm{~nm}$ & 41 \\
\hline 4 & 2 & 1 & $\operatorname{DCM}(0.2)$ & 3 & $365 \mathrm{~nm}$ & 48 \\
\hline 5 & 2 & 1 & toluene $(0.2)$ & 3 & $365 \mathrm{~nm}$ & $75(67)$ \\
\hline 6 & 1 & 1 & $\mathrm{CH}_{3} \mathrm{CN}(0.2)$ & 3 & $365 \mathrm{~nm}$ & 0 \\
\hline 7 & 2 & 1 & $\mathrm{Et}_{2} \mathrm{O}(0.2)$ & 3 & $365 \mathrm{~nm}$ & 0 \\
\hline $8^{c}$ & 2 & 1 & toluene $(0.2)$ & 3 & $365 \mathrm{~nm}$ & 9 \\
\hline 9 & 2 & 1 & toluene $(0.2)$ & 3 & in dark & 0 \\
\hline
\end{tabular}

[a] unless untill mentioned all reactions were carried out in $0.1 \mathrm{mmol}$ scale in respective dry solvents. [b] yield was measured by ${ }^{1} \mathrm{H}-\mathrm{NMR}$ analysis of the crude reaction mixture using $\mathrm{CH}_{2} \mathrm{Br}_{2}$ as an internal standard, isolated yield in parentheses. [c] UV strip was used as a light source instead of UV LEDs. 
Supplementary Information

\section{General Procedures:}

\subsection{General procedure for preparation of $\alpha$-diazoesters $\left(\right.$ GP-1). ${ }^{\mathrm{S} 1}$}

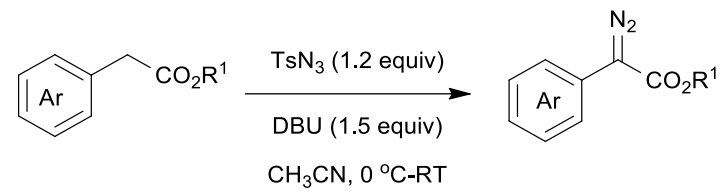

According to previous literature, ${ }^{S 1} \alpha$-diazoesters were prepared. To a mixture of ester ( 1 equiv, $\left.10 \mathrm{mmol}\right)$ and tosyl azide (1.2 equiv, $12 \mathrm{mmol}$ ) in anhydrous $\mathrm{CH}_{3} \mathrm{CN}(15 \mathrm{~mL})$ at $0{ }^{\circ} \mathrm{C}, 1,8$-diazabicyclo[5.4.0]undec-7-ene (DBU) (1.5 equiv, $15 \mathrm{mmol}$ ) was added. The reaction mixture was then stirred at room temperature for overnight. Upon complete consumption of the starting materials, the reaction mixture was quenched with saturated aqueous solution of $\mathrm{NH}_{4} \mathrm{Cl}(5 \mathrm{~mL})$, extracted with $\mathrm{CH}_{2} \mathrm{Cl}_{2}$, washed with brine, dried over $\mathrm{MgSO}_{4}$, and concentrated under reduced pressure to give the product. The residue was purified by coloumn chromatography (hexane/EtOAc, 9:1) to afford the $\alpha$-diazoesters (1a-1d).

\subsection{General procedure for preparation of $\alpha$-diazoesters (GP-2). ${ }^{\mathrm{S} 2, \mathrm{~S} 1}$}

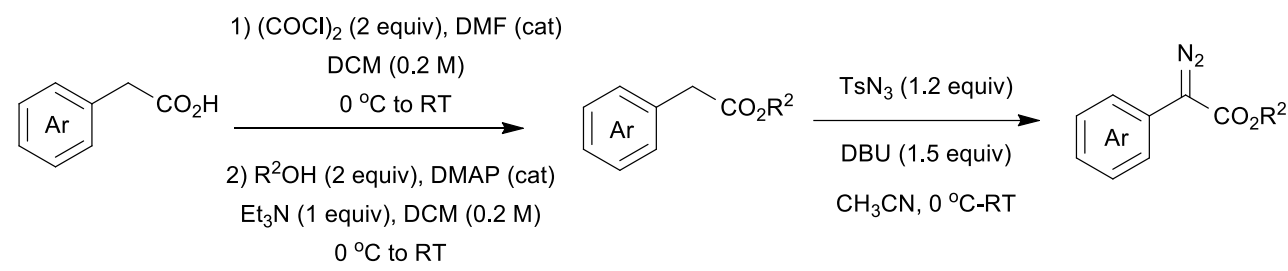

According to previous literature, ${ }^{\mathrm{S} 2, \mathrm{~S} 1} \alpha$-diazoesters were prepared. At room temperature, under nitrogen, a round bottom flask is charged with 2-arylacetic acid (1 equiv, $15 \mathrm{mmol}$ ), DCM (0.2 M) and oxalyl chloride (2 equiv, 30 mmol). The temperature is cooled to $0{ }^{\circ} \mathrm{C}$ and DMF (1-2 drops) is added. The reaction temperature is allowed to warm up to room temperature and stirred at this temperature overnight. Then, the reaction mixture is concentrated under reduced pressure. Next, at room temperature, under nitrogen, the round bottom flask containing the previously prepared acyl chloride is charged with ROH (1.2 equiv, $18 \mathrm{mmol}$ ), DMAP (0.1 equiv, $0.15 \mathrm{mmol}$ ), Et $3 \mathrm{~N}$ (1.0 equiv, $15 \mathrm{mmol})$ and DCM $(0.2 \mathrm{M})$. The reaction is stirred at room temperature overnight. Then, the reaction is quenched with a saturated aqueous solution of $\mathrm{NH}_{4} \mathrm{Cl}$, extracted with $\mathrm{DCM}$, dried $\left(\mathrm{MgSO}_{4}\right)$, filtered and concentrated under reduced pressure. The obtained residue is purified by flash column chromatography to afford the corresponding esters. These esters then were converted into corresponding $\alpha$-diazoesters $(\mathbf{3 f}, \mathbf{3 g}, \mathbf{3 h}, \mathbf{3 i}, \mathbf{3 k}, \mathbf{3 m})$ by following $\mathbf{G P}$ 1. 
Supplementary Information

5.3. General procedure for preparation of $\alpha$-diazoesters (GP-3). ${ }^{\mathrm{S} 2, \mathrm{~S} 1}$

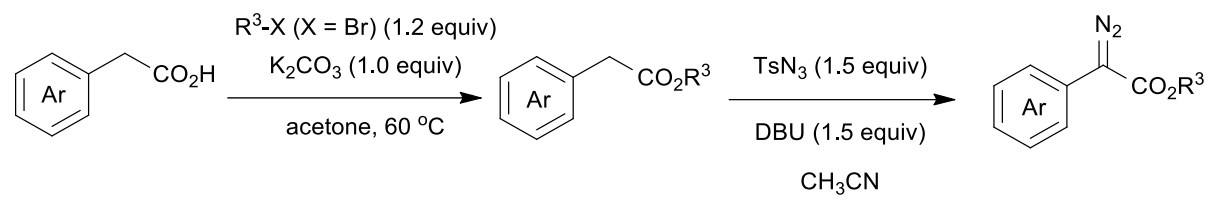

According to previous literature, ${ }^{\text {S2, S1 }} \alpha$-diazoesters were prepared. Under air, a round bottomed flask is charged with the carboxylic acid (1 equiv), acetone $(0.5 \mathrm{M})$ ), alkyl halide (1.2 equiv) and $\mathrm{K}_{2} \mathrm{CO}_{3}$ (1 equiv). The reaction mixture is heated at reflux $\left(60{ }^{\circ} \mathrm{C}\right)$ overnight. Then, the reaction is allowed to cool to room temperature and is concentrated under vacuum. The residue is dissolved in EtOAc, washed with $\mathrm{H}_{2} \mathrm{O}$, brine, dried $\left(\mathrm{MgSO}_{4}\right)$ and concentrated again under reduced pressure. Purification by flash column chromatography affords the corresponding esters. These esters then were converted into corresponding $\alpha$-diazoesters $(\mathbf{3 j}, \mathbf{3 l})$ by following $\mathbf{G P - 1}$.

\subsection{General procedure for preparation of ethyl 2-diazo-2-(thiophen-2-yl)acetate (GP-4). ${ }^{\mathrm{S}}$}

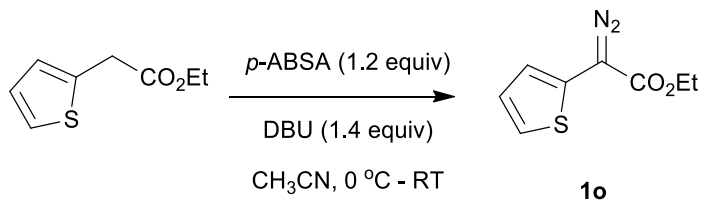

According to previous literature, ${ }^{\mathrm{S} 3} \alpha$-diazoester was prepared. To a $100 \mathrm{~mL}$ round bottom flask equipped with a magnetic stir bar, $\alpha$-arylacetate $(10 \mathrm{mmol})$ and $p$-acetamidobencenesulfonylazide $(12 \mathrm{mmol}, 2.88 \mathrm{~g})$ were added to prechilled $\mathrm{CH}_{3} \mathrm{CN}(25 \mathrm{~mL})$. DBU $(14 \mathrm{mmol}, 1.40 \mathrm{~mL})$ was then added dropwise to the mixture. Upon complete consumption of the starting materials monitored by TLC, the reaction mixture was diluted with distilled water (20 $\mathrm{mL})$ and extracted with diethyl ether $(3 \times 10 \mathrm{~mL})$. The organic layer was then washed with $10 \% \mathrm{NaHCO}_{3}$ solution $(3 \mathrm{X} 10 \mathrm{~mL})$ and brine $(3 \times 10 \mathrm{~mL})$. The combined organic extracts were dried over anhydrous $\mathrm{MgSO}_{4}$ and concentrated under reduced pressure. The aryl diazoacetate (1o) was purified by coloumn chromatography (eluent: Hexane/EtOAc, 20:1).

5.5. General procedure for preparation of tert-butyl 3-(1-diazo-2-methoxy-2-oxoethyl)-1H-indole-1carboxylate (GP-5). ${ }^{\mathrm{S}}$
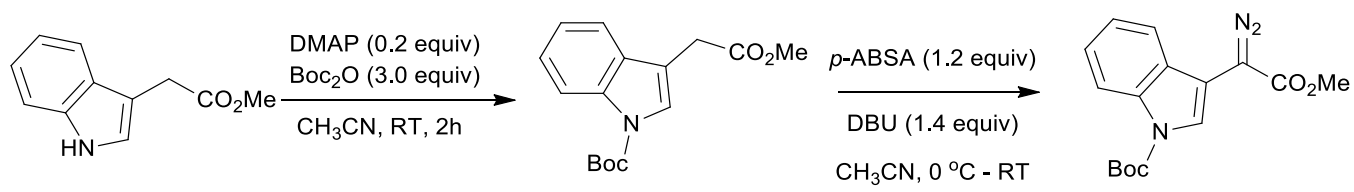
Supplementary Information

According to previous literature, ${ }^{\mathrm{S}}{ }^{\alpha}$-diazoester were prepared. Methyl 2-( $1 H$-indol-3-yl)acetate $(1.3 \mathrm{~g}, 6.39 \mathrm{mmol})$ was diluted in $\mathrm{CH}_{3} \mathrm{CN}$, then DMAP $(0.16 \mathrm{~g}, 1.3 \mathrm{mmol})$ and $\mathrm{Boc}_{2} \mathrm{O}(1.53 \mathrm{~g}, 7.03 \mathrm{mmol})$ were added. The reaction mixture was stirred at $\mathrm{rt}$ for $2 \mathrm{~h}$ then concentrated in vacuo, diluted in $\mathrm{CH}_{2} \mathrm{Cl}_{2}$ washed with water, brine, dried $\left(\mathrm{Na}_{2} \mathrm{SO}_{4}\right)$ and concentrated in vacuo. Purification by silica gel chromatography (9:1 pentane:EtOAc) gave tert-butyl 3-(2-methoxy-2-oxoethyl)-1H-indole-1-carboxylate. In the next step, $p$-ABSA (2.72 g, $11.4 \mathrm{mmol}$ ) was added to a solution of tert-butyl 3-(2-methoxy-2-oxoethyl)- $1 H$-indole-1-carboxylate $(1.897 \mathrm{~g}, 12.1 \mathrm{mmol})$ and DBU $(5.75 \mathrm{~g}$, $5.65 \mathrm{~mL}, 37.8 \mathrm{mmol})$ in $\mathrm{CH}_{3} \mathrm{CN}(12 \mathrm{~mL})$ at $0{ }^{\circ} \mathrm{C}$. The reaction mixture was allowed to warm to $\mathrm{rt}$ over $3 \mathrm{~h}$, then concentrated in vacuo and diluted in $\mathrm{CH}_{2} \mathrm{Cl}_{2}$. The organic phase was washed with $0.5 \mathrm{M} \mathrm{pH} 7$ sodium phosphate buffer solution, dried $\left(\mathrm{Na}_{2} \mathrm{SO}_{4}\right)$ and concentrated in vacuo. Purification by silica gel chromatography (94:6 pentane:Et $\left.{ }_{2} \mathrm{O}\right)$ gave tert-butyl 3-(1-diazo-2-methoxy-2-oxoethyl)-1 $H$-indole-1-carboxylate (1n) as pink solid.

\subsection{General procedure for preparation of $\alpha$-diazo- $\beta$-keto esters (GP-6). ${ }^{\mathrm{S} 5}, \mathrm{~S} 6, \mathrm{~S} 27$}

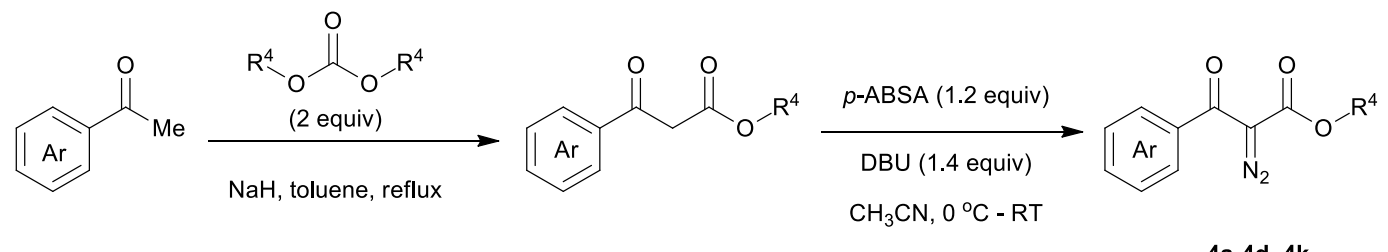

According to previous literature, ${ }^{\mathrm{S} 5}$ acetoacetate derivatives were prepared. To a dried $100 \mathrm{~mL}$ three-necked flask were added $\mathrm{NaH}(2.2 \mathrm{~g}, 60 \% \mathrm{w} / \mathrm{w}, 56 \mathrm{mmol})$, dimethyl carbonate or diethyl carbonate (40 mmol), and toluene (20 $\mathrm{mL}$ ) under nitrogen. After the reaction mixture was heated to reflux in oil bath, a solution of acetophenone (20 $\mathrm{mmol}$ ) in toluene $(10 \mathrm{~mL})$ was added dropwise over $0.5 \mathrm{~h}$. After the evolution of hydrogen ceased (30-45 min), the reaction was cooled down to room temperature. Glacial acetic acid $(6 \mathrm{~mL})$ was added dropwise and a heavy pasty solid was separated. Ice-cold water was slowly added until the solid was dissolved completely. Then, the reaction system was diluted with EtOAc. The organic layer was separated, washed with water $(20 \mathrm{~mL})$ and then saturated brine $(20 \mathrm{~mL})$ and finally dried over anhydrous $\mathrm{Na}_{2} \mathrm{SO}_{4}$. After the solvent was evaporated with the aid of rotary evaporator, the residue was purified by flash chromatography on silica gel with EtOAc/hexanes.

In the next step, according to previous literature, ${ }^{\mathrm{S6}, \mathrm{S} 27} \alpha$-diazoesters were prepared. To a solution of acetoacetate derivatives ( 1 equiv, $5 \mathrm{mmol}$ ) and $p$-acetamidobenzenesulfonyl azide ( $p$-ABSA) (1.2 equiv, $6 \mathrm{mmol}$ ) in anhydrous $\mathrm{CH}_{3} \mathrm{CN}$ at $0{ }^{\circ} \mathrm{C}$, triethylamine $\left(\mathrm{Et}_{3} \mathrm{~N}\right)(3$ equiv, $15 \mathrm{mmol})$ was added dropwise. After stirring at room temperature for $5 \mathrm{~h}$ the reaction mixture was concentrated in vacuo. Water $(20 \mathrm{~mL})$ was added. The resulting mixture was extracted with diethyl ether $(2$ X $20 \mathrm{~mL})$. The combined organic layer was washed with brine $(20 \mathrm{~mL})$ and dried over $\mathrm{MgSO}_{4}$. The solvent was removed under reduced pressure, and the residue was purified by a silica gel column chromatography with petroleum ether/ethyl acetate as the eluent to give the entitled diazo compounds $(\mathbf{4 a - 4 d , ~} \mathbf{4 k})$. 
Supplementary Information

\subsection{General procedure for preparation of diazoacetophenone (GP-7). ${ }^{\mathrm{S} 7}$}

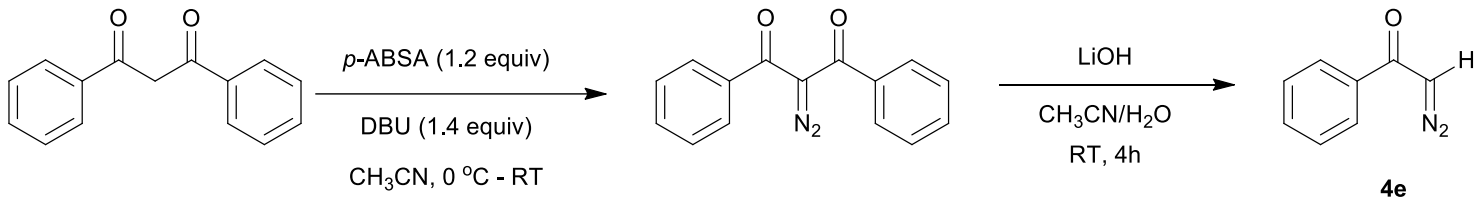

According to previous literature, ${ }^{57}$ to a solution of 1,3-diphenylpropanedione ( $\left.896 \mathrm{mg}, 4 \mathrm{mmol}\right)$ and $\mathrm{Et}_{3} \mathrm{~N}(0.6 \mathrm{~mL}$, $4.2 \mathrm{mmol})$ in acetonitrile $(20 \mathrm{~mL})$, a solution of $p$-ABSA $(1200 \mathrm{mg}, 5 \mathrm{mmol})$ in $20 \mathrm{~mL}$ acetonitrile was added dropwise with stirring. The reaction mixture was stirred at room temperature overnight. The compound 2-diazo-1,3diphenylpropane-1,3-dione was purified by column chromatography (silica gel) using PE/EA 20:1 as eluent. The compound was then dissolved in acetonitrile $(20 \mathrm{~mL})$. Aqueous $\mathrm{LiOH}$ solution $(8.5 \mathrm{mmol} \mathrm{LiOH}$ in $20 \mathrm{~mL}$ water) was added and the reaction mixture was stirred at room temperature for $4 \mathrm{~h}$. After that, the reaction mixture was rotary evaporated at $30{ }^{\circ} \mathrm{C}$ under reduced pressure to remove most of acetonitrile. $20 \mathrm{~mL}$ water was added, and then the product was extracted by dichloromethane at least 3 times and finally purified by column chromatography (silica gel) using PE/EA 10:1 to give as a yellow solid (4e).

\subsection{General procedure for preparation of $\alpha$-diazoketones (GP-8): ${ }^{88, ~ S 9}$}

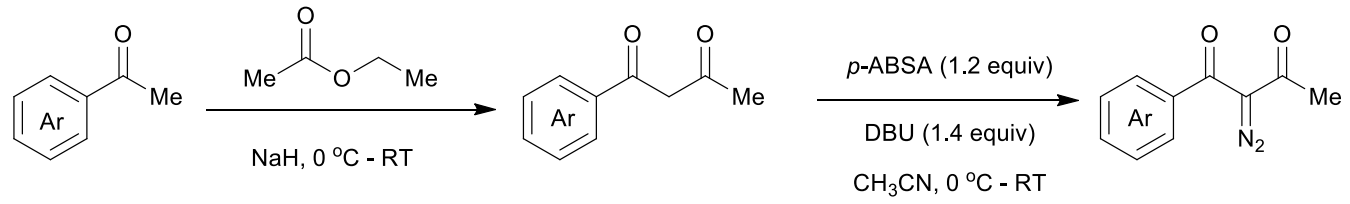

According to previous literature,$^{\mathrm{S} 8}$ 1-arylbutane-1,3-diones were prepared. To an oven dried round-bottom flask, substituted aryl ketone $(515 \mathrm{mg}, 4.3 \mathrm{mmol})$ and ethyl acetate $(20 \mathrm{~mL})$ followed by $\mathrm{NaH}(17.2 \mathrm{mmol}, 60 \%$ in dispersions oil) was added at $0{ }^{\circ} \mathrm{C}$, The resultant reaction mixture was stirred at room temperature for $24 \mathrm{~h}$. Then, it was quenched with saturated $\mathrm{NH}_{4} \mathrm{Cl}$ solution, extracted with EtOAc $(3 \mathrm{X} 25 \mathrm{~mL})$ and the combined layer was dried over $\mathrm{Na}_{2} \mathrm{SO}_{4}$. The evaporation of solvent under the reduced under pressure followed by purification using column chromatography afforded the products.

According to previous literature, ${ }^{\mathrm{S} 9} 1$-arylbutane-1,3-diones were converted into corresponding diazoketones. To an oven-dried round-bottom flask equipped with a magnetic stirring bar 1-arylbutane-1,3-dione (1 equiv, $10 \mathrm{mmol}$ ) and p-ABSA (1.2 equiv, $12 \mathrm{mmol}$ ) were added, and the system was filled with nitrogen. Acetonitrile was then added, and the reaction mixture was cooled to $0{ }^{\circ} \mathrm{C}$ using an ice-bath. Triethylamine ( 2 equiv, $20 \mathrm{mmol}$ ) was added dropwise within $2 \mathrm{~min}$; the reaction mixture was slowly warmed to room temperature, and allowed to stir for $8 \mathrm{~h}$. A white precipitate of $\mathrm{N}$-(4-sulfamoylphenyl)acetamide was filtered and washed with dicloromethane $(2 \mathrm{X} 10 \mathrm{~mL})$. Solvents were evaporated, and diazo compound $(\mathbf{4 f}, \mathbf{4 g})$ was purified by column chromatography on silica gel with a 9:1 to $4: 1(\mathrm{v} / \mathrm{v})$ gradient of hexane:ethyl acetate as eluents. 
Supplementary Information

5.9. General procedure for preparation of $\alpha$-aryldiazoketone (GP-9): ${ }^{\mathrm{S} 10}$

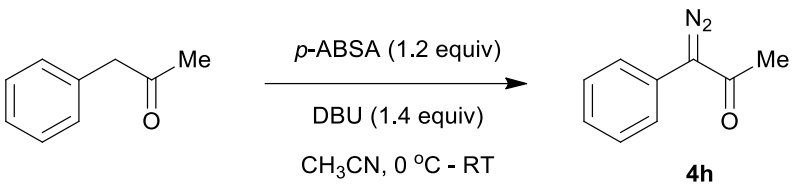

According to previous literature, ${ }^{510}$ diazocompound $\mathbf{4 g}$ was prepared. To a solution of 1-Phenylpropan-2-one (1.34 $\mathrm{g}, 10 \mathrm{mmol})$ and $p$-ABSA $(2.88 \mathrm{~g}, 12 \mathrm{mmol})$ in dry $\mathrm{CH}_{3} \mathrm{CN}(20 \mathrm{~mL})$ was added DBU $(1.94 \mathrm{~mL}, 13 \mathrm{mmol})$ drop wise at $0{ }^{\circ} \mathrm{C}$. Then the mixture was stirred overnight at room temperature. The reaction was then quenched with $10 \mathrm{wt} \%$ $\mathrm{NaOH}(\mathrm{aq})$, followed by extraction with $\mathrm{Et}_{2} \mathrm{O}(2 \times 20 \mathrm{~mL})$. The combined organic extracts were anhydrous $\mathrm{MgSO}_{4}$, filtered and concentrated under reduced pressure. The yellow crude product was purified by silica gel column chromatography (petroleum ether: $\left.\mathrm{Et}_{2} \mathrm{O}=10: 1\right)$ to give the product as a yellow solid $(\mathbf{4 h})$.

\subsection{General procedure for the preparation of oxoacetate derivatives (GP-10):}

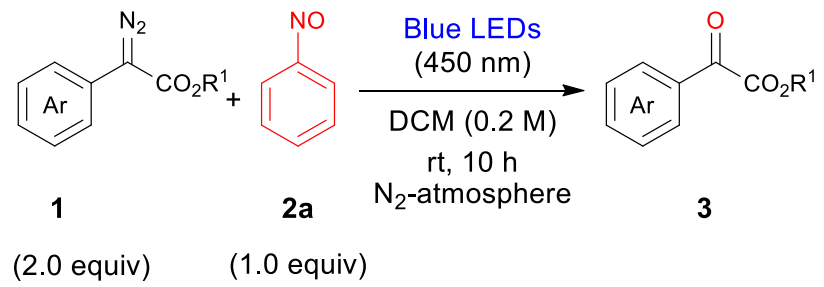

In an oven-dried vial equipped with a Teflon-coated stir bar, $\alpha$-diazoesters $1(0.2 \mathrm{mmol}, 2$ equiv) and nitrosobenzene 2a (0.1 mmol, 1 equiv) were added. Dry DCM $(0.2 \mathrm{M})$ was added to the reaction mixture under $\mathrm{N}_{2}$ atmosphere. Then this reaction mixture was purged for at least 15 min by using a nitrogen balloon and was sealed. The reaction mixture was then irradiated under blue LEDs for $10 \mathrm{~h}$. After completion, the solvent was evaporated under reduced pressure. Analytically pure products were obtained by column chromatography on silica gel using petroleum ether and ethyl acetate as eluents.

\subsection{General procedure for the preparation of oxazetidine derivatives (GP-11):}

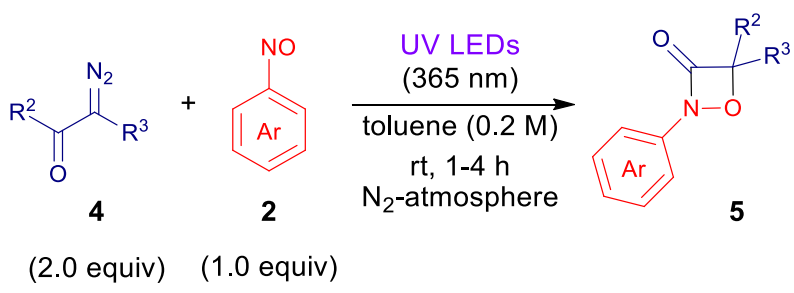


Supplementary Information

In an oven-dried vial equipped with a Teflon-coated stir bar, $\alpha$-diazoesters 1 ( $0.2 \mathrm{mmol}, 2$ equiv) and nitrosobenzene $2\left(0.1 \mathrm{mmol}, 1\right.$ equiv) were added. Dry Toluene $(0.2 \mathrm{M})$ was added to the reaction mixture under $\mathrm{N}_{2}$ atmosphere. Then this reaction mixture was purged for at least $15 \mathrm{~min}$ by using a nitrogen balloon and was sealed. The reaction mixture was then irradiated under UV LEDs for 1-4 h. After completion, the solvent was evaporated under reduced pressure. Analytically pure products were obtained by column chromatography on silica gel using petroleum ether and ethyl acetate as eluents.

Note: These oxazetidine derivatives are unstable in nature, needs a quick isolation and data recording process.

\subsection{General procedure for the reduction of oxazetidine derivative to prepare 6a (GP-12):}

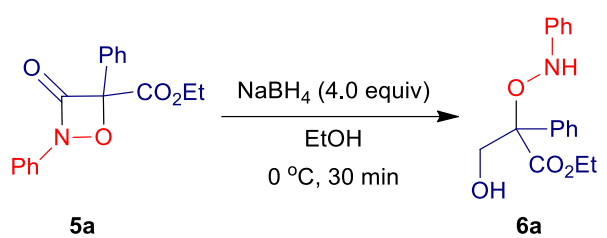

In an oven dried ordinary vial equipped with a Teflon-coated stir bar and a plastic screw cap compound 5a (0.05 mmol, $15.0 \mathrm{mg}, 1.0$ equiv) was taken and diluted with $1.0 \mathrm{~mL}$ of ethanol. Then to this mixture solid $\mathrm{NaBH}_{4}(0.2$ mmol, 4.0 equiv) were added and kept at $0{ }^{\circ} \mathrm{C}$ for 30 minutes. The reaction was quenched by adding few drops of water. Brine $(5 \mathrm{~mL})$ was added and resulted mixture was extracted with DCM ( 3 X $10 \mathrm{~mL})$, dried over $\mathrm{MgSO}_{4}$, filtered and concentrated in vacuo. The analytically pure product was obtained by column chromatography on silica gel using petroleum ether and ethyl acetate as eluent.

\subsection{General procedure for the reduction of oxazetidine derivative to prepare $6 \mathrm{~b}(\mathrm{GP}-13)$ :}

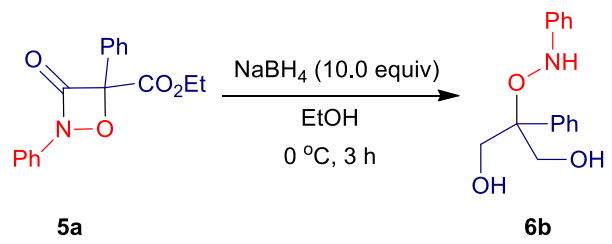

In an oven dried ordinary vial equipped with a Teflon-coated stir bar and a plastic screw cap compound 5a $(0.05$ mmol, $15.0 \mathrm{mg}, 1.0$ equiv) was taken and diluted with $1.0 \mathrm{~mL}$ of ethanol. Then to this mixture solid $\mathrm{NaBH}_{4}(0.5$ mmol, 10.0 equiv) were added and kept at $0{ }^{\circ} \mathrm{C}$ for $3 \mathrm{~h}$. The reaction was quenched by adding few drops of water. Brine $(5 \mathrm{~mL})$ was added and resulted mixture was extracted with DCM (3 X $10 \mathrm{~mL})$, dried over $\mathrm{MgSO}_{4}$, filtered and concentrated in vacuo. The analytically pure product was obtained by column chromatography on silica gel using petroleum ether and ethyl acetate as eluent. 


\subsection{General procedure for the reduction of oxazetidine derivative to prepare $6 \mathrm{~b}(\mathrm{GP}-14)$ :}

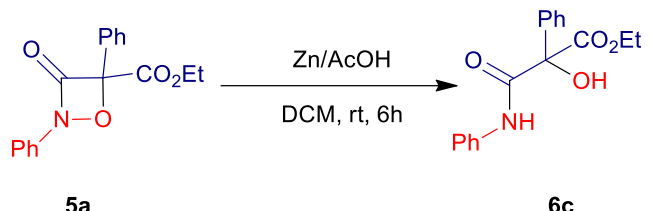

To the suspension of 1,2-oxazetidin-3-one $5 \mathbf{a}(15.0 \mathrm{mg}, 0.05 \mathrm{mmol}, 1.0$ equiv) and zinc powder (16.0 $\mathrm{mg}, 0.25$ mmol, 5 equiv) in DCM $(1 \mathrm{~mL})$ was added dropwise the solution of acetic acid ( $14 \mu \mathrm{L}, 0.25 \mathrm{mmol}, 5$ equiv) in DCM $(0.3 \mathrm{~mL})$ in $3 \mathrm{~h}$. The mixture was stirred for an additional $3 \mathrm{~h}$ at $\mathrm{rt}$, and then the solids were removed by filtration through Celite. The filtrate was concentrated under reduced pressure. The analytically pure product was obtained by column chromatography on silica gel using petroleum ether and ethyl acetate as eluent. 
Supplementary Information

\section{Control Experiments and UV-Visible spectra:}

\subsection{Control Experiments:}
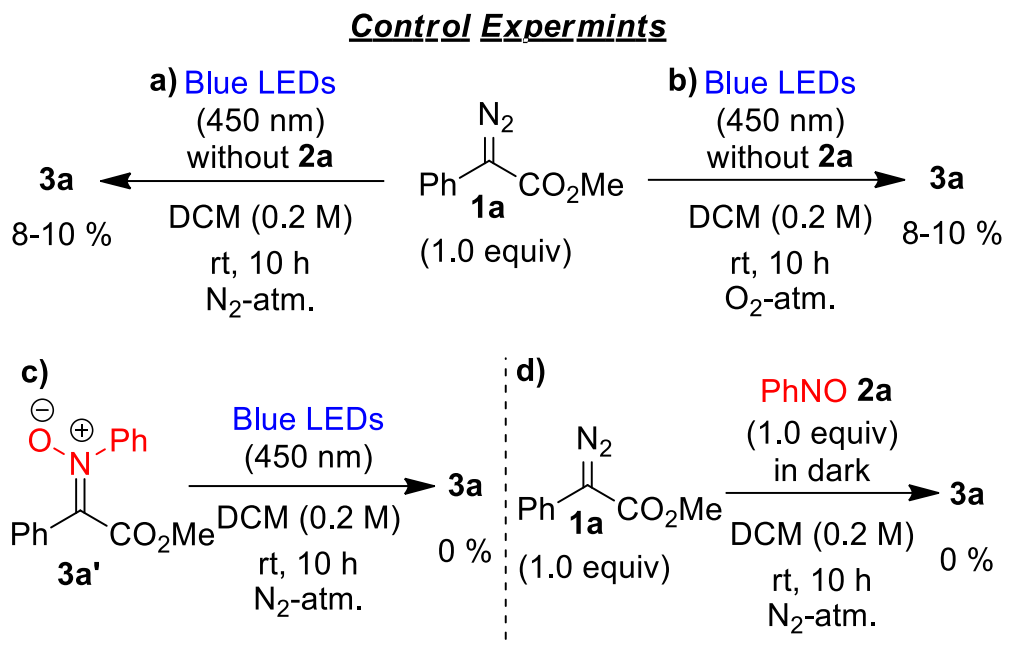

\subsection{UV-Visible Spectra:}

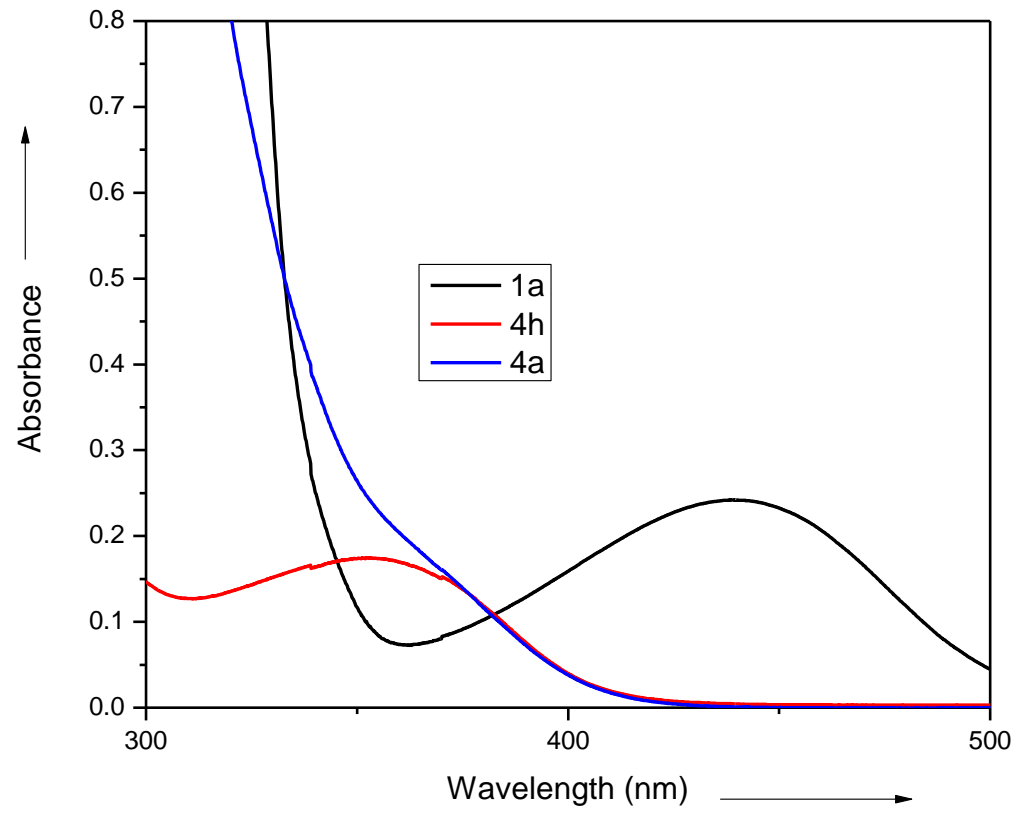

Figure S2: UV-Visible absorption spectra of compound 1a, $\mathbf{4 a}$, and $\mathbf{4 h}(0.002 \mathrm{M}$ in toluene). 
Supplementary Information

\section{Plausible Mechanism:}

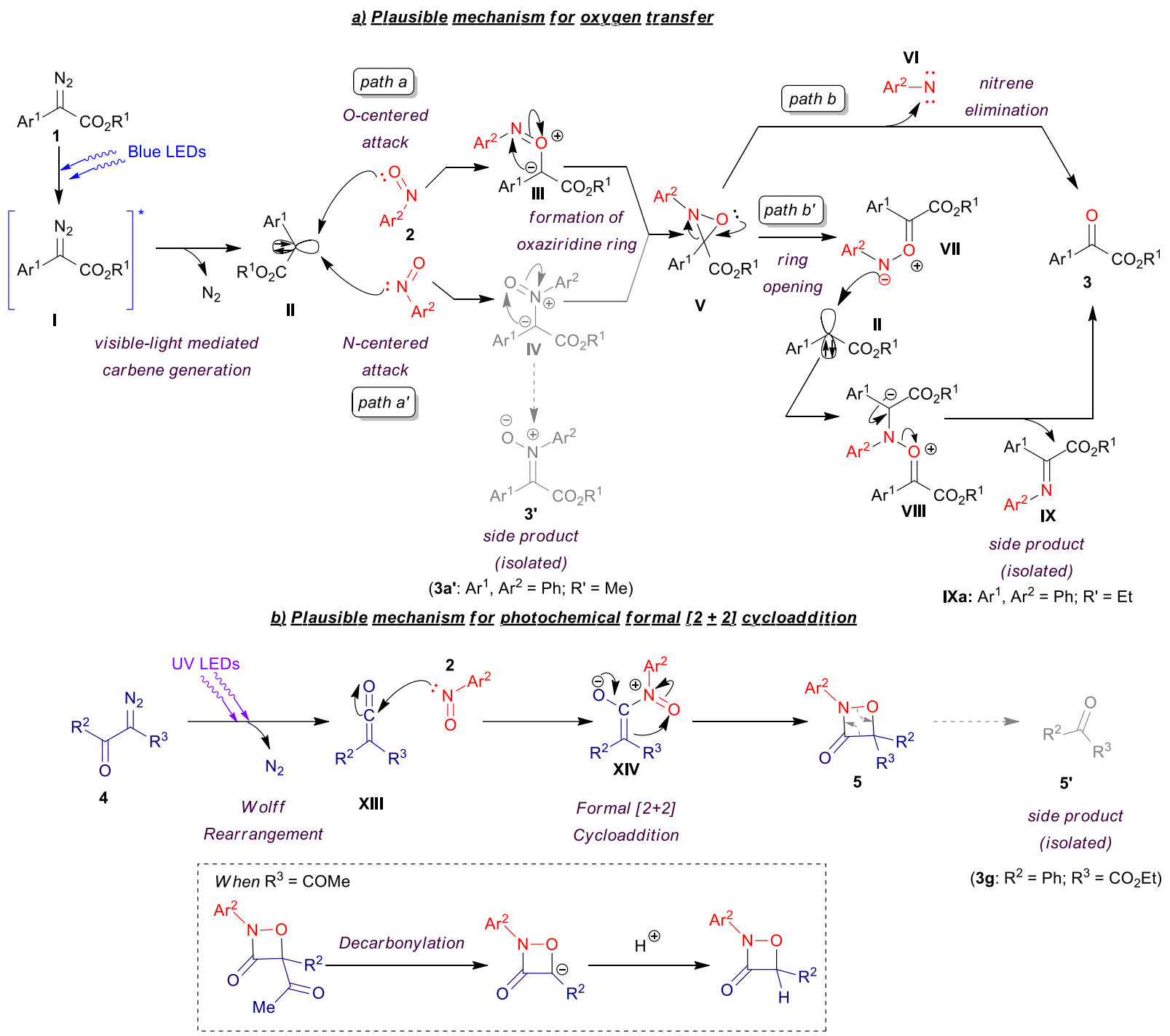

7.1. $N$-(2-methoxy-2-oxo-1-phenylethylidene)aniline oxide (3a'):

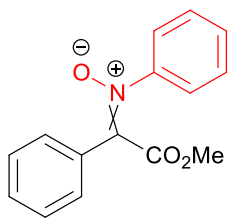

3a'

$\mathrm{C}_{15} \mathrm{H}_{13} \mathrm{NO}_{3}$

M. W. $255.27 \mathrm{~g} / \mathrm{mol}$

${ }^{1} \mathbf{H}$ NMR (400 MHz, CDCl $): \delta 8.08-8.06(\mathrm{~m}, 2 \mathrm{H}), 7.45-7.38(\mathrm{~m}, 8 \mathrm{H}), 3.50(\mathrm{~s}, 3 \mathrm{H}),{ }^{13} \mathbf{C}$ NMR $\left(\mathbf{1 0 1} \mathbf{~ M H z}, \mathbf{C D C l}_{\mathbf{3}}\right)$ : $\delta 172.2,155.3,138.7,135.6,132.1,129.4,128.5,128.4,128.2,128.1,54.0$. 
Supplementary Information

HRMS (ESI): m/z [M+H] ${ }^{+}$Calculated for $\left[\mathrm{C}_{15} \mathrm{H}_{14} \mathrm{NO}_{3}\right]^{+}:$256.0974; Found: 256.0970 .
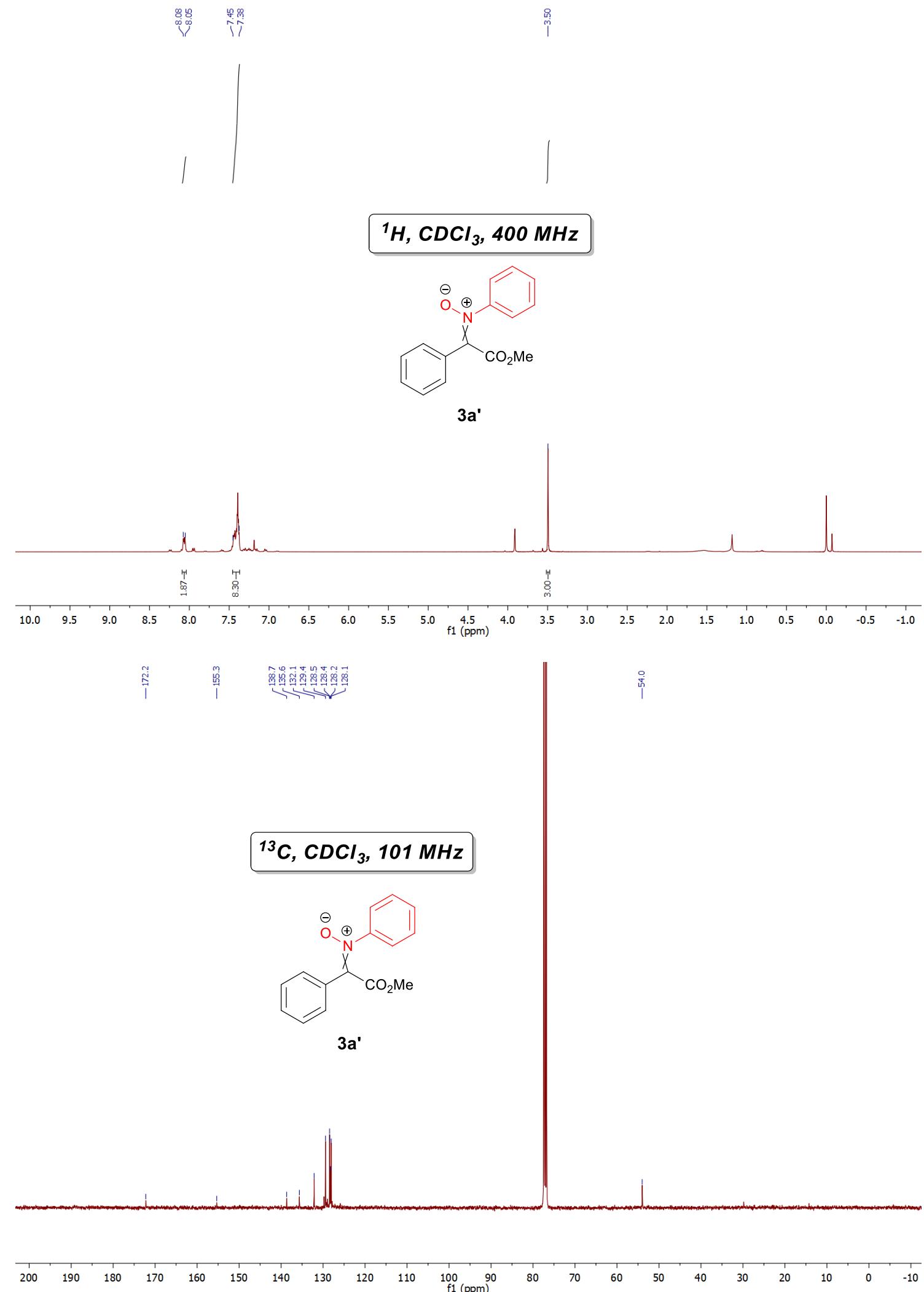
7.2. (E)-ethyl 2-phenyl-2-(phenylimino)acetate (IXa):<smiles>CCOC(=O)/C(=N\c1ccccc1)c1ccccc1</smiles>

\section{IXa}

$$
\mathrm{C}_{16} \mathrm{H}_{15} \mathrm{NO}_{2}
$$

M. W. $253.29 \mathrm{~g} / \mathrm{mol}$

According to GP-10 side product IXa was obtained while preparing compound $\mathbf{3 g}$ by using $\mathbf{1 g}(38.0 \mathrm{mg}, 0.2 \mathrm{mmol}$, 2.0 equiv) and $2 \mathrm{a}\left(11.0 \mathrm{mg}, 0.1 \mathrm{mmol}, 1.0\right.$ equiv) in $\mathrm{CH}_{2} \mathrm{Cl}_{2}$ for $10 \mathrm{~h}$ at rt. Column chromatographic purification (petroleum ether/EtOAc 99:1 to 95:5) afforded IXa (side product) as yellow oil (9.0 mg, 36\%).

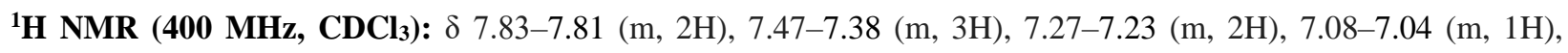
6.90-6.88 (m, 2H), 4.05 (q, J = 7.1 Hz, 2H), 0.92 (t, $J=7.1 \mathrm{~Hz}, 3 \mathrm{H}) .{ }^{13} \mathbf{C}$ NMR (101 MHz, CDCl $)$ ): $\delta$ 163.9, 159.2, $149.1,132.8,130.7,127.7,127.7,127.0,123.8,118.5,60.4,12.7$.

HRMS (ESI): $\mathrm{m} / \mathrm{z}[\mathrm{M}+\mathrm{H}]^{+}$Calculated for $\left[\mathrm{C}_{16} \mathrm{H}_{16} \mathrm{NO}_{2}\right]^{+}: 254.1181$; Found: 254.1141.

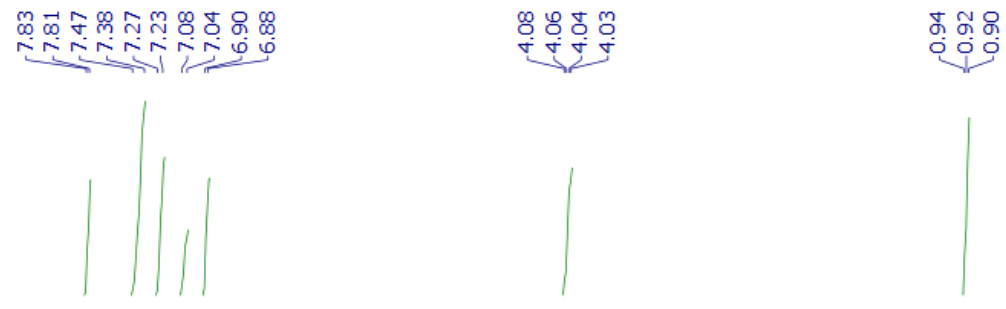

\section{${ }^{1} \mathrm{H}, \mathrm{CDCl}_{3}, 400 \mathrm{MHz}$}<smiles>[R14]C(=O)/C(=N/c1ccccc1)c1ccccc1</smiles>

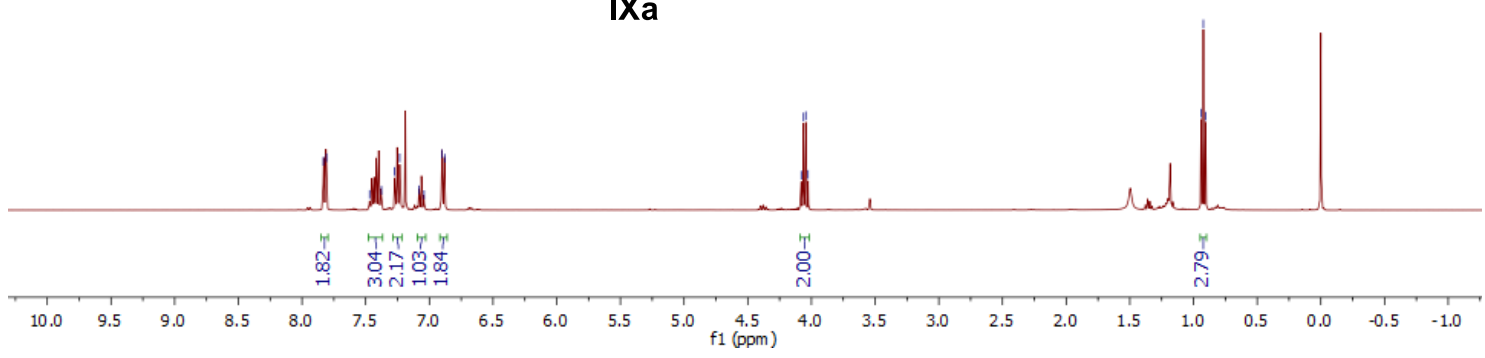


Supplementary Information

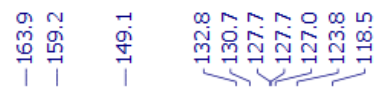

范

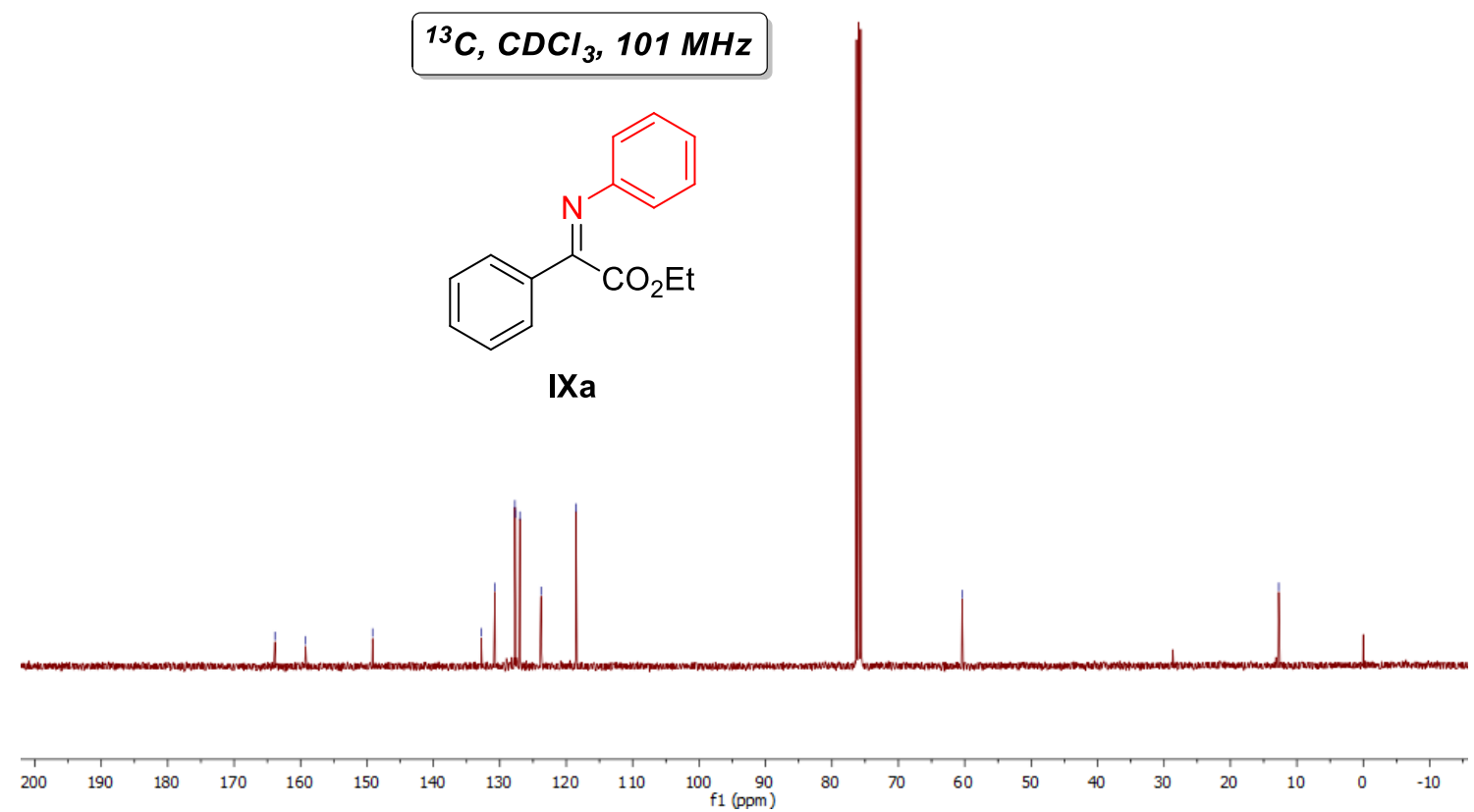


Supplementary Information

\subsection{Synthetic Applications:}

a) One pot synthesis of methyl 2-oxo-2phenylacetate from methyl 2-phenylacetate

1) $\mathrm{TsN}_{3}, \mathrm{DBU}$<smiles>COC(=O)Cc1ccccc1</smiles>

1a' Blue LEDs $(450 \mathrm{~nm}) \quad \mathbf{3 a}, 31 \%$

$\mathrm{N}_{2}$-atm.

b) C-N bond cleavage of oxazetidine ring

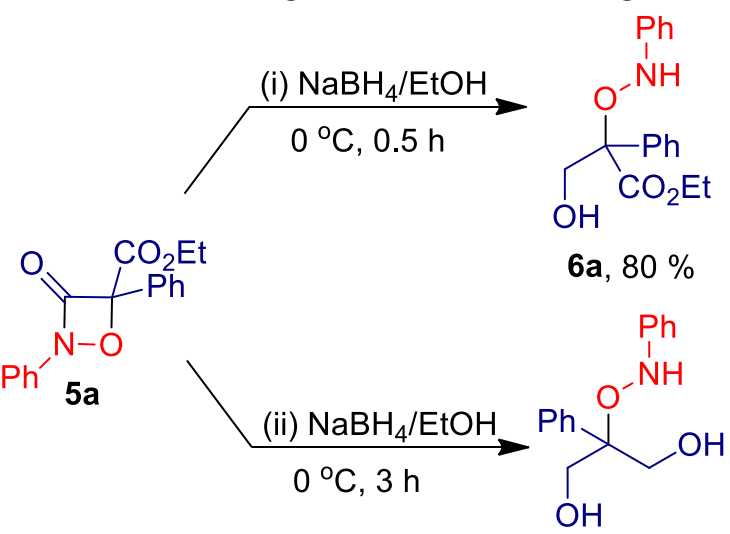

6b, $77 \%$

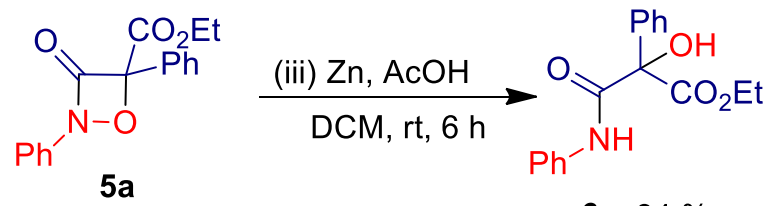

$6 c, 84 \%$ 
Supplementary Information

\section{References:}

S1. Keipour, H.; Ollevier T. Org. Lett. 2017, 19, 5736-5739.

S2. Thurow, S.; Fernandes, A. A. G.; Quevedo-Acosta, Y.; de Oliveira, M. F.; de Oliveira, M. G.; Jurberg, I. D.

Org. Lett. 2019, 21, 6909-6913.

S3. Chan, Q.; Xing, Y.-C.; Chow, S.-F.; Hung, Yu, W.-Y. Org. Lett. 2019, 21, 8037-8043.

S4. Davies, H. M. L.; Townsend, R. J. J. Org. Chem. 2001, 66, 6595-6603.

S5. Jiang, Y.; Chen, X.; Zheng, Y.; Xue, Z.; Shu, C.; Yuan, W.; Zhang, X. Angew. Chem. Int. Ed. 2011, 50, 7304-7307.

S6. Wang, J.; Wang, M.; Chen, K.; Zha, S.; Song, C.; Zhu, J. Org. Lett. 2016, 18, 1178-1181.

S7. Liu, Q.; Li, M.; Xiong, R.; Mo, F. Org. Lett. 2017, 19, 6756-6759.

S8. Rajasekar, S.; Anbarasan, P. Chem. Asian J. 2019, 14, 4563-4567.

S9. Marichev, K. O.; Wang, Y.; Carranco, A. M.; Garcia, E. C.; Yu, Z.-X.; Doyle, M. P. Chem. Commun., 2018, 54, 9513-9516.

S10. Yang, J.; Ke, C.; Zhang, D.; Liu, X.; Feng, X. Org. Lett. 2018, 20, 4536-4539.

S11. Lippincott, D. J.; Linstadt, R. T. H.; Maser, M. R.; Gallou, F.; Lipshutz, B. H. Org. Lett. 2018, 20, 47194722.

S12. Tibiletti, F.; Simonetti, M.; Nicholas, K. M.; Palmisano, G.; Parravicini, M.; Imbesi, F.; Tollari, S.; Penoni, A. Tetrahedron, 2010, 66, 1280-1288.

S13. Priewisch, B.; Braun, K. R. J. Org. Chem., 2005, 70, 2350-2352.

S14. Dochnahl, M.; Fu, G. C. Angew. Chem. Int. Ed., 2009, 48, 2391-2393.

S15. Jankowiak, A.; Obijalska, E.; Kaszynski, P.; Pieczonka, A.; Young, V. G. Tetrahedron 2011, 67, 33173327.

S16. Arcadi, A.; Chiarini, M.; Vecchio, L. D.; Marinelli, F.; Michelet, V. Chem. Commun. 2016, 52, 14581461.

S17. Defoin, A. Synthesis, 2004, 5, 706-710.

S18. Min, G. M.; Bang, S.; Lee, H.; Yu, B. C. Chem. Commun. 2010, 46, 5232-5234.

S19. Yu, Q.; Zhang, Y.; Wan, J.-P. Green Chem., 2019, 21, 3436-3441.

S20. Liu, R.; Liu, Q.; Meng, H.; Ding, H.; Hao, J.; Ji, Z.; Yue, H.; Wei, W. Org. Chem. Front., 2021, 8, 1970-1975.

S21. Wang, S. R.; Radosevich, A. T. Org. Lett. 2015, 17, 3810-3813.

S22. Battula, S.; Battini, N.; Singh, D.; Ahmed, Q. N. Org. Biomol. Chem., 2015, 13, 8637-8641.

S23. Raghunadha, A.; Meruvaa, S. B.; Kumara, N. A.; Kumara, G. S.; Raob, L. V.; Kumar, U. K. S. Synthesis 2012, 2, 283-289.

S24. Luo, X.; He, R.; Liu, Q.; Gao, Y.; Li, J.; Chen, X.; Zhu, Z.; Huang, Y.; Li, Y. J. Org. Chem. 2020, 85, $5220-5230$.

S25. Markey, S. J.; Lewis, W.; Moody, C. J. Org. Lett. 2013, 15, 6306-6308.

S26. Dochnahl, M.; Fu, G. C. Angew. Chem. Int. Ed., 2009, 48, 2391-2393.

S27. Long, Z.; Wang, Z.; Zhou, D.; Wan, D.; You, J. Org. Lett. 2017, 19, 2777-2780. 
Supplementary Information

\section{Result \& Characterization:}

\section{1. methyl 2-oxo-2-phenylacetate (3a):}

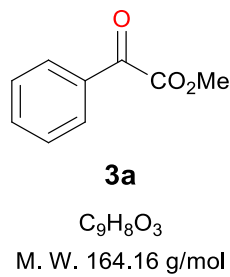

According to GP-10 compound 3a was prepared by using 1a (35.0 mg, $0.2 \mathrm{mmol}, 2.0$ equiv) and $\mathbf{2 a}$ (11.0 mg, 0.1 mmol, 1.0 equiv) in $\mathrm{CH}_{2} \mathrm{Cl}_{2}$ for $10 \mathrm{~h}$ at rt. Column chromatographic purification (petroleum ether/EtOAc 99:1 to 95:5) afforded 3a as colourless oil (12.5 mg, 76\%). For $1.0 \mathrm{mmol}$ scale reaction: 1a (352.0 mg, $1.0 \mathrm{mmol}, 2.0$ equiv), 2a (1.0 equiv, $1 \mathrm{mmol}, 107.0 \mathrm{mg})$, in dry DCM ( $5 \mathrm{~mL}, 0.2 \mathrm{M})$ was used and reaction was stirred for $15 \mathrm{~h}$ to get $68 \%$ isolated yield of $\mathbf{3 a}(112.0 \mathrm{mg})$.

${ }^{1} \mathbf{H}$ NMR (400 MHz, CDCl3): $\delta 8.02-8.00(\mathrm{~m}, 2 \mathrm{H}), 7.68-7.64(\mathrm{~m}, 1 \mathrm{H}), 7.53-7.49(\mathrm{~m}, 2 \mathrm{H}), 3.97(\mathrm{~s}, 3 \mathrm{H}) .{ }^{13} \mathbf{C} \mathbf{N M R}$ (101 MHz, CDCl 3$): \delta 186.1,164.1,135.1,132.5,130.2,129.0,52.9$.

These data are in accordance with the previous report. ${ }^{\mathrm{S} 19}$

\section{2. methyl 2-(4-methoxyphenyl)-2-oxoacetate (3b):}

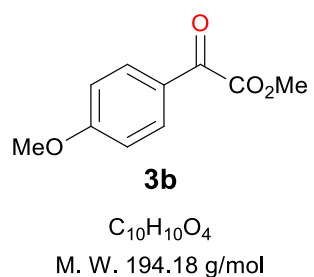

According to GP-10 compound $\mathbf{3 b}$ was prepared by using $\mathbf{1 b}(41.0 \mathrm{mg}, 0.2 \mathrm{mmol}, 2.0$ equiv) and $\mathbf{2 a}$ (11.0 $\mathrm{mg}, 0.1$ mmol, 1.0 equiv) in $\mathrm{CH}_{2} \mathrm{Cl}_{2}$ for $10 \mathrm{~h}$ at rt. Column chromatographic purification (petroleum ether/EtOAc 97:3 to 90:10) afforded $\mathbf{3 b}$ as white solid (14.0 $\mathrm{mg}, 72 \%)$.

Melting Point: $48-50{ }^{\circ} \mathrm{C}$.

${ }^{1} \mathbf{H}$ NMR (400 MHz, CDCl $)$ ): $\delta$ 8.02-7.98 (m, 2H), 6.98-6.94 (m, 2H), 3.95 (s, 3H), 3.88 (s, 3H). ${ }^{13} \mathbf{C}$ NMR (101 MHz, $\left.\mathbf{C D C l}_{3}\right): \delta$ 184.5, 165.2, 164.4, 132.8, 125.5, 114.3, 55.8, 52.8.

These data are in accordance with the previous report. ${ }^{\mathrm{S} 20}$

\section{3. methyl 2-(4-fluorophenyl)-2-oxoacetate (3c):}




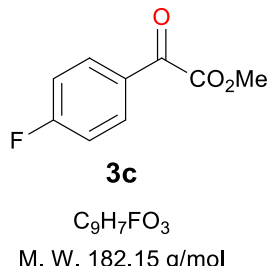

According to GP-10 compound 3c was prepared by using 1c (39.0 mg, $0.2 \mathrm{mmol}, 2.0$ equiv) and $2 \mathbf{a}$ (11.0 mg, 0.1 mmol, 1.0 equiv) in $\mathrm{CH}_{2} \mathrm{Cl}_{2}$ for $10 \mathrm{~h}$ at $\mathrm{rt}$. Column chromatographic purification (petroleum ether/EtOAc 97:1 to 95:5) afforded $\mathbf{3 c}$ as colourless oil (15.0 $\mathrm{mg}, 83 \%)$.

${ }^{1}$ H NMR (400 MHz, CDCl $)$ : $\delta$ 8.10-8.06 (m, 2H), 7.20-7.16 (m, 2H), 3.97 (s, 3H). ${ }^{13} \mathbf{C}$ NMR (101 MHz, CDCl $)$ : $\delta 184.2,167.0(\mathrm{~d}, J=258.6 \mathrm{~Hz}), 163.7,133.1(\mathrm{~d}, J=9.8 \mathrm{~Hz}), 129.0(\mathrm{~d}, J=3.4 \mathrm{~Hz}), 116.4(\mathrm{~d}, J=22.3 \mathrm{~Hz}), 53.0 .{ }^{19} \mathbf{F}$ NMR: (376 MHz, $\left.\mathbf{C D C l}_{3}\right): \delta-100.9$.

These data are in accordance with the previous report. ${ }^{\mathrm{S} 20}$

\section{4. methyl 2-(4-chlorophenyl)-2-oxoacetate (3d):}

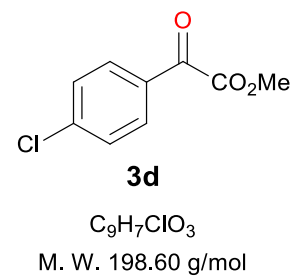

According to GP-10 compound 3d was prepared by using 1d (42.0 mg, $0.2 \mathrm{mmol}, 2.0$ equiv) and $2 \mathbf{a}$ (11.0 mg, 0.1 mmol, 1.0 equiv) in $\mathrm{CH}_{2} \mathrm{Cl}_{2}$ for $10 \mathrm{~h}$ at rt. Column chromatographic purification (petroleum ether/EtOAc 99:1 to 95:5) afforded 3d as colourless oil (16.0 $\mathrm{mg}, 81 \%)$.

${ }^{1}$ H NMR (400 MHz, CDCl $): \delta 8.00-7.97$ (m, 2H), 7.50-7.46 (m, 2H), 3.97 (s, 3H). ${ }^{13} \mathbf{C}$ NMR (101 MHz, CDCl $)$ : $\delta$ 184.6, 163.5, 141.9, 131.6, 130.9, 129.4, 53.1.

These data are in accordance with the previous report. ${ }^{\mathrm{S} 2}$

\section{5. methyl 2-(2-bromophenyl)-2-oxoacetate (3e):}

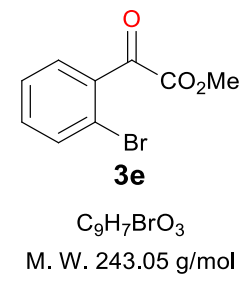


Supplementary Information

According to GP-10 compound 3e was prepared by using $1 \mathbf{e}(51.0 \mathrm{mg}, 0.2 \mathrm{mmol}, 2.0$ equiv) and $\mathbf{2 a}(11.0 \mathrm{mg}, 0.1$ mmol, 1.0 equiv) in $\mathrm{CH}_{2} \mathrm{Cl}_{2}$ for $10 \mathrm{~h}$ at rt. Column chromatographic purification (petroleum ether/EtOAc 98:2 to 95:5) afforded 3e as light yellow oil (18.0 mg, 74\%).

${ }^{1} \mathbf{H}$ NMR (400 MHz, CDCl): $\delta$ 7.68-7.66 (m, 1H), 7.64-7.62 (m, 1H), 7.47-7.40 (m, 2H), $3.94(\mathrm{~s}, 3 \mathrm{H}) .{ }^{13} \mathbf{C}$ NMR (101 MHz, CDCl $\mathbf{3}): \delta 187.1,162.9,135.6,134.2,133.8,131.9,127.8,121.7,53.5$.

These data are in accordance with the previous report. ${ }^{\mathrm{S} 21}$

9.6. methyl 2-(naphthalen-2-yl)-2-oxoacetate (3f):

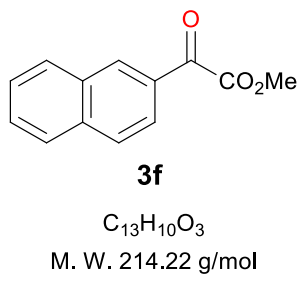

According to GP-10 compound $\mathbf{3 f}$ was prepared by using $\mathbf{1 f}(45.0 \mathrm{mg}, 0.2 \mathrm{mmol}, 2.0$ equiv) and $\mathbf{2 a}$ (11.0 $\mathrm{mg}, 0.1$ mmol, 1.0 equiv) in $\mathrm{CH}_{2} \mathrm{Cl}_{2}$ for $10 \mathrm{~h}$ at rt. Column chromatographic purification (petroleum ether/EtOAc 97:3 to 90:10) afforded $\mathbf{3 f}$ as light yellow oil (14.0 $\mathrm{mg}, 65 \%)$.

${ }^{1} \mathbf{H}$ NMR (400 MHz, CDCl 3$): \delta 8.56(\mathrm{~s}, 1 \mathrm{H}), 8.04(\mathrm{dd}, J=8.7,1.8 \mathrm{~Hz}, 1 \mathrm{H}), 7.98(\mathrm{~d}, J=8.2 \mathrm{~Hz}, 1 \mathrm{H}), 7.93(\mathrm{~d}, J=$ $8.7 \mathrm{~Hz}, 1 \mathrm{H}), 7.89(\mathrm{~d}, J=8.3 \mathrm{~Hz}, 1 \mathrm{H}), 7.65(\mathrm{ddd}, J=8.2,7.0,1.2 \mathrm{~Hz}, 1 \mathrm{H}), 7.58$ (ddd, $J=8.1,7.0,1.2 \mathrm{~Hz}, 1 \mathrm{H}), 4.03$

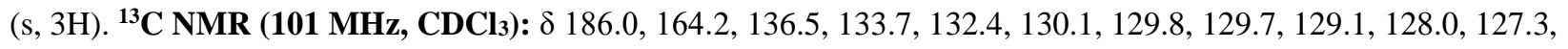
124.1, 53.0.

These data are in accordance with the previous report. ${ }^{\mathrm{S} 22}$

\section{7. ethyl 2-oxo-2-phenylacetate (3g):}

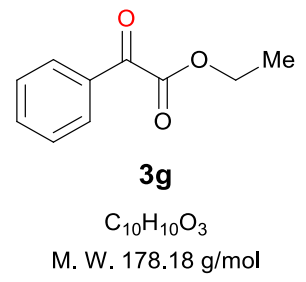

According to GP-10 compound $\mathbf{3 g}$ was prepared by using $\mathbf{1 g}(38.0 \mathrm{mg}, 0.2 \mathrm{mmol}, 2.0$ equiv) and $\mathbf{2 a}(11.0 \mathrm{mg}, 0.1$ mmol, 1.0 equiv) in $\mathrm{CH}_{2} \mathrm{Cl}_{2}$ for $10 \mathrm{~h}$ at rt. Column chromatographic purification (petroleum ether/EtOAc 99:1 to 95:5) afforded $\mathbf{3 g}$ as colourless oil (13.5 $\mathrm{mg}, 76 \%)$.

${ }^{1} \mathbf{H}$ NMR (400 MHz, CDCl $)$ ): $\delta$ 8.01-7.98 (m, 2H), 7.67-7.63 (m, 1H), 7.52-7.48 (m, 2H), $4.44(\mathrm{q}, J=7.1 \mathrm{~Hz}, 2 \mathrm{H})$, $1.41(\mathrm{t}, J=7.1 \mathrm{~Hz}, 3 \mathrm{H}) .{ }^{13} \mathbf{C} \mathbf{N M R}\left(\mathbf{1 0 1} \mathbf{M H z}, \mathbf{C D C l}_{3}\right): \delta 186.5,163.9,135.0,132.5,130.1,129.0,62.5,14.2$. 
Supplementary Information

These data are in accordance with the previous report. ${ }^{\mathrm{S} 19}$

\section{8. methyl 2-oxo-2-(o-tolyl)acetate (3h):}

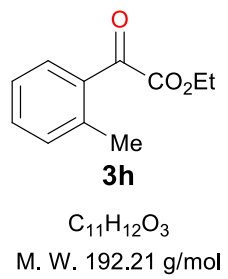

According to GP-10 compound $3 \mathbf{h}$ was prepared by using $\mathbf{1 h}(38.0 \mathrm{mg}, 0.2 \mathrm{mmol}, 2.0$ equiv) and $\mathbf{2 a}(11.0 \mathrm{mg}, 0.1$ mmol, 1.0 equiv) in $\mathrm{CH}_{2} \mathrm{Cl}_{2}$ for $10 \mathrm{~h}$ at rt. Column chromatographic purification (petroleum ether/EtOAc 98:2 to 95:5) afforded $3 \mathbf{h}$ as colourless oil (12.0 $\mathrm{mg}, 67 \%)$.

${ }^{1}$ H NMR (400 MHz, CDCl $)$ ): $\delta$ 7.69-7.67 (m, 1H), 7.50-7.46 (m, 1H), 7.33-7.29 (m, 2H), 4.42 (q, J = 7.1 Hz, 2H), 2.60 (s, 3H), 1.40 (t, $J=7.1 \mathrm{~Hz}, 3 \mathrm{H}) .{ }^{13} \mathbf{C}$ NMR (101 MHz, $\left.\mathbf{C D C l}_{3}\right): \delta 188.9,164.7,141.5,133.8,132.4(2 \mathrm{C}), 131.3$, $126.0,62.4,21.6,14.2$.

These data are in accordance with the previous report. ${ }^{\mathrm{S} 19}$

\section{9. isopropyl 2-oxo-2-phenylacetate (3i):}

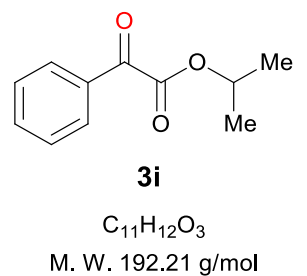

According to GP-10 compound 3i was prepared by using $1 \mathbf{1}(38.0 \mathrm{mg}, 0.2 \mathrm{mmol}, 2.0$ equiv) and $2 \mathbf{a}$ (11.0 mg, 0.1 mmol, 1.0 equiv) in $\mathrm{CH}_{2} \mathrm{Cl}_{2}$ for $10 \mathrm{~h}$ at rt. Column chromatographic purification (petroleum ether/EtOAc 99:1 to 95:5) afforded $3 \mathbf{i}$ as light yellow oil (12.0 mg, 62\%).

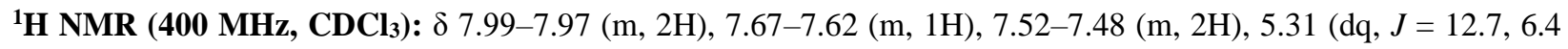
$\mathrm{Hz}, 1 \mathrm{H}), 1.40(\mathrm{~d}, J=6.1 \mathrm{~Hz}, 6 \mathrm{H}) .{ }^{13} \mathbf{C}$ NMR (101 MHz, CDCl$): ~ \delta 186.8,163.7,134.9,132.6,130.1,129.0,70.8$, 21.8 .

These data are in accordance with the previous report. ${ }^{\mathrm{S} 19}$ 
Supplementary Information

\subsection{0. benzyl 2-oxo-2-phenylacetate (3j):}

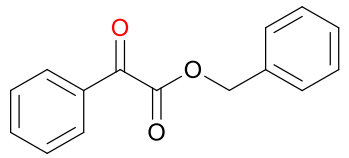

3j

$\mathrm{C}_{15} \mathrm{H}_{12} \mathrm{O}_{3}$

M. W. $240.25 \mathrm{~g} / \mathrm{mol}$

According to GP-10 compound $\mathbf{3 j}$ was prepared by using $\mathbf{1 j}(50.0 \mathrm{mg}, 0.2 \mathrm{mmol}, 2.0$ equiv) and $\mathbf{2 a}$ (11.0 $\mathrm{mg}, 0.1$ mmol, 1.0 equiv) in $\mathrm{CH}_{2} \mathrm{Cl}_{2}$ for $10 \mathrm{~h}$ at rt. Column chromatographic purification (petroleum ether/EtOAc 99:1 to 95:5) afforded $\mathbf{3 j}$ as colourless oil (16.0 $\mathrm{mg}, 67 \%)$.

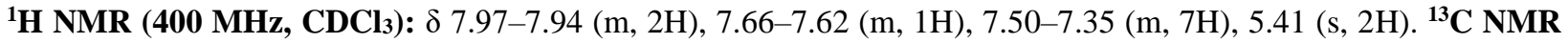
(101 MHz, $\left.\mathbf{C D C l}_{3}\right): \delta$ 186.2, 163.7, 135.1, 134.6, 132.5, 130.1, 129.0, 128.9 (2C), 128.7, 67.9.

These data are in accordance with the previous report. ${ }^{\mathrm{S} 20}$

\subsection{1. allyl 2-oxo-2-phenylacetate (3k):}

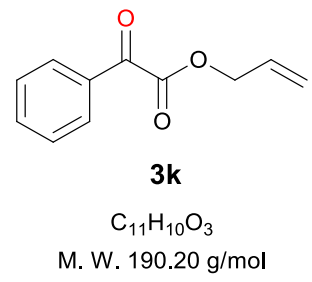

According to GP-10 compound 3k was prepared by using 1k (40.0 mg, $0.2 \mathrm{mmol}, 2.0$ equiv) and $\mathbf{2 a}(11.0 \mathrm{mg}, 0.1$ mmol, 1.0 equiv) in $\mathrm{CH}_{2} \mathrm{Cl}_{2}$ for $10 \mathrm{~h}$ at rt. Column chromatographic purification (petroleum ether/EtOAc 99:1 to 95:5) afforded 3k as light yellow oil (14.0 $\mathrm{mg}, 74 \%)$.

${ }^{1} \mathbf{H}$ NMR (400 MHz, CDCl $): \delta 8.01-7.99(\mathrm{~m}, 2 \mathrm{H}), 7.68-7.64(\mathrm{~m}, 1 \mathrm{H}), 7.53-7.49(\mathrm{~m}, 2 \mathrm{H}), 6.07-5.96(\mathrm{~m}, 1 \mathrm{H}), 5.44$ $(\mathrm{dq}, J=17.3,1.3 \mathrm{~Hz}, 1 \mathrm{H}), 5.34(\mathrm{dq}, J=10.2,0.9 \mathrm{~Hz}, 1 \mathrm{H}), 4.87(\mathrm{dt}, J=5.9,1.2 \mathrm{~Hz}, 2 \mathrm{H}) .{ }^{13} \mathbf{C}$ NMR $(\mathbf{1 0 1} \mathbf{M H z}$, $\left.\mathbf{C D C l}_{3}\right): \delta$ 186.2, 163.5, 135.1, 132.5, 130.8, 130.2, 129.0, 120.2, 66.7.

These data are in accordance with the previous report. ${ }^{\mathrm{S} 20}$

\subsection{2. prop-2-yn-1-yl 2-oxo-2-phenylacetate (31):}

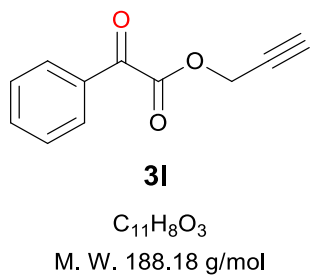


Supplementary Information

According to GP-10 compound 31 was prepared by using 11 (40.0 mg, $0.2 \mathrm{mmol}, 2.0$ equiv) and $\mathbf{2 a}$ (11.0 mg, 0.1 mmol, 1.0 equiv) in $\mathrm{CH}_{2} \mathrm{Cl}_{2}$ for $10 \mathrm{~h}$ at rt. Column chromatographic purification (petroleum ether/EtOAc 98:2 to 95:5) afforded $\mathbf{3 l}$ as colourless oil (13.0 $\mathrm{mg}, 69 \%)$.

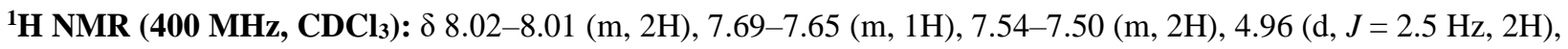
$2.59(\mathrm{t}, J=2.5 \mathrm{~Hz}, 1 \mathrm{H}) .{ }^{13} \mathbf{C}$ NMR (126 MHz, $\left.\mathbf{C D C l}\right)$ : $\delta$ 185.2, 162.8, 135.2, 132.3, 130.1, 129.0, 77.2, 76.3, 53.3.

These data are in accordance with the previous report. ${ }^{523}$

\subsection{3. (1R,2S,5R)-2-isopropyl-5-methylcyclohexyl 2-oxo-2-phenylacetate (3m):}

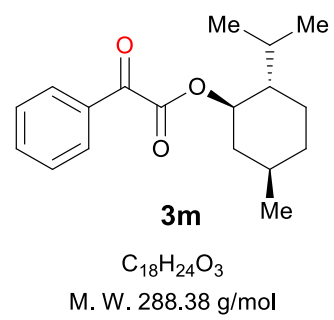

According to GP-10 compound 3m was prepared by using $\mathbf{1 m}(60.0 \mathrm{mg}, 0.2 \mathrm{mmol}, 2.0$ equiv) and $\mathbf{2 a}(11.0 \mathrm{mg}, 0.1$ mmol, 1.0 equiv) in $\mathrm{CH}_{2} \mathrm{Cl}_{2}$ for $10 \mathrm{~h}$ at rt. Column chromatographic purification (petroleum ether/EtOAc 97:3 to 90:10) afforded $\mathbf{3 m}$ as colourless oil (20.0 $\mathrm{mg}, 69 \%)$.

${ }^{1}$ H NMR (400 MHz, CDCl3): $\delta$ 7.98-7.95 (m, 2H), 7.67-7.63 (m, 1H), 7.53-7.49 (m, 2H), 4.99 (td, $J=11.0,4.4$ $\mathrm{Hz}, 1 \mathrm{H}), 2.17(\mathrm{~m}, 1 \mathrm{H}), 1.94(\mathrm{pd}, J=7.0,2.7 \mathrm{~Hz}, 1 \mathrm{H}), 1.75-1.68(\mathrm{~m}, 2 \mathrm{H}), 1.62-1.47(\mathrm{~m}, 3 \mathrm{H}), 1.24-1.05(\mathrm{~m}, 2 \mathrm{H})$, $0.95(\mathrm{~d}, J=6.6 \mathrm{~Hz}, 3 \mathrm{H}), 0.89(\mathrm{~d}, J=7.0 \mathrm{~Hz}, 3 \mathrm{H}), 0.83(\mathrm{~d}, J=6.9 \mathrm{~Hz}, 3 \mathrm{H}) .{ }^{13} \mathbf{C} \mathbf{N M R}(\mathbf{1 0 1} \mathbf{M H z}, \mathbf{C D C l}): \delta 186.9$, 164.0, 134.9, 132.6, 130.0, 129.0, 46.9, 40.7, 34.1, 31.6, 26.2, 23.4, 22.1, 20.8, 16.2.

These data are in accordance with the previous report. ${ }^{\mathrm{S} 24}$

\subsection{4. ethyl 2-oxo-2-(thiophen-2-yl)acetate (3n):}

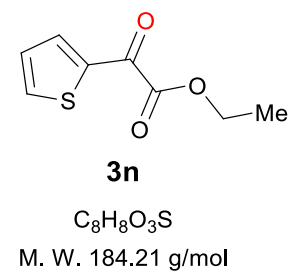

According to GP-10 compound 3n was prepared by using $\mathbf{1 n}(39.0 \mathrm{mg}, 0.2 \mathrm{mmol}, 2.0$ equiv) and $\mathbf{2 a}$ (11.0 mg, 0.1 mmol, 1.0 equiv) in $\mathrm{CH}_{2} \mathrm{Cl}_{2}$ for $10 \mathrm{~h}$ at rt. Column chromatographic purification (petroleum ether/EtOAc 97:3 to 90:10) afforded $\mathbf{3 n}$ as yellow oil (11.0 mg, 60\%). 
Supplementary Information

${ }^{1} \mathbf{H}$ NMR (400 MHz, CDCl $): \delta 8.13(\mathrm{dd}, J=3.9,1.2 \mathrm{~Hz}, 1 \mathrm{H}), 7.81(\mathrm{dd}, J=4.9,1.1 \mathrm{~Hz}, 1 \mathrm{H}), 7.19(\mathrm{dd}, J=4.8,4.0$ Hz, 1H), 4.42 (q, $J=7.2 \mathrm{~Hz}, 2 \mathrm{H}), 1.42(\mathrm{t}, J=7.2 \mathrm{~Hz}, 3 \mathrm{H}) .{ }^{13} \mathbf{C} \mathbf{~ N M R}\left(\mathbf{1 0 1} \mathbf{~ M H z}, \mathbf{C D C l}_{\mathbf{3}}\right): \delta$ 176.5, 161.7, 139.1, 137.6, 137.3, 128.7, 62.9, 14.1.

These data are in accordance with the previous report. ${ }^{\mathrm{S} 19}$

9.15. tert-butyl 3-(2-methoxy-2-oxoacetyl)-1H-indole-1-carboxylate (3o):

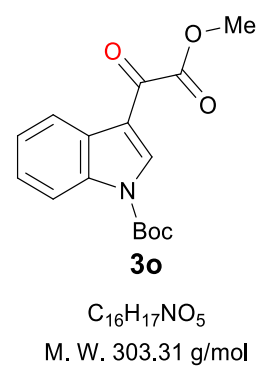

According to GP-10 compound 30 was prepared by using $10(63.0 \mathrm{mg}, 0.2 \mathrm{mmol}, 2.0$ equiv) and $2 \mathbf{a}(11.0 \mathrm{mg}, 0.1$ mmol, 1.0 equiv) in $\mathrm{CH}_{2} \mathrm{Cl}_{2}$ for $10 \mathrm{~h}$ at rt. Column chromatographic purification (petroleum ether/EtOAc 97:3 to 90:10) afforded 30 as colourless soild (14.0 $\mathrm{mg}, 46 \%)$.

Melting Point: $128-130^{\circ} \mathrm{C}$

HRMS (ESI): $\mathrm{m} / \mathrm{z}[\mathrm{M}+\mathrm{Na}]^{+}$Calculated for $\left[\mathrm{C}_{16} \mathrm{H}_{17} \mathrm{NO}_{5}+\mathrm{Na}\right]^{+}: 326.1004$; Found: 326.0997

${ }^{1} \mathbf{H}$ NMR (400 MHz, CDCl 3 ): $\delta 8.80(\mathrm{~s}, 1 \mathrm{H}), 8.40-8.38(\mathrm{~m}, 1 \mathrm{H}), 8.17-8.15(\mathrm{~m}, 1 \mathrm{H}), 7.43-7.36(\mathrm{~m}, 2 \mathrm{H}), 3.97(\mathrm{~s}$, 3H), 1.70 (s, 9H). ${ }^{13} \mathbf{C}$ NMR (101 MHz, $\left.\mathbf{C D C l}_{3}\right): \delta$ 178.8, 162.4, 148.8, 137.3, 135.4, 127.5, 126.2, 125.0, 122.7, 116.3, 115.2, 86.0, 53.1, 28.1.

These data are in accordance with the previous report. ${ }^{\mathrm{S} 25}$

9.16. ethyl 3-oxo-2,4-diphenyl-1,2-oxazetidine-4-carboxylate (5a):

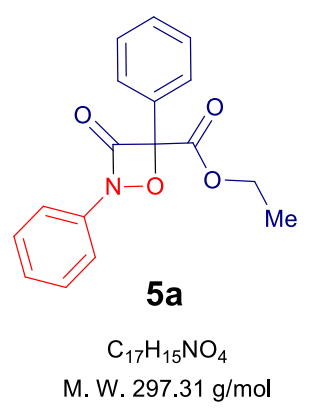


Supplementary Information

According to GP-11 compound 5a was prepared by using $4 \mathbf{a}(44.0 \mathrm{mg}, 0.2 \mathrm{mmol}, 2.0$ equiv) and $\mathbf{2 a}(11.0 \mathrm{mg}, 0.1$ mmol, 1.0 equiv) in toluene for $3 \mathrm{~h}$ at $\mathrm{rt}$. Column chromatographic purification (petroleum ether/EtOAc 99:1 to 95:5) afforded 5a as light green oil (20.0 mg, 67\%). For $1.0 \mathrm{mmol}$ scale reaction: 1a (436.0 mg, $1.0 \mathrm{mmol}, 2.0$ equiv), $2 \mathrm{a}$ (1.0 equiv, $1 \mathrm{mmol}, 107.0 \mathrm{mg}$ ), in dry toluene $(5 \mathrm{~mL}, 0.2 \mathrm{M})$ was used and reaction was stirred for $5 \mathrm{~h}$ to get $57 \%$ isolated yield of $\mathbf{5 a}(170.0 \mathrm{mg})$.

HRMS (ESI): $\mathrm{m} / \mathrm{z}[\mathrm{M}+\mathrm{Na}]^{+}$Calculated for $\left[\mathrm{C}_{17} \mathrm{H}_{15} \mathrm{NNaO}_{4}\right]^{+}: 320.0899$; Found: 320.0879 .

${ }^{1}$ H NMR (400 MHz, CDCl$)$ : $\delta$ 7.65-7.62 (m, 2H), 7.46-7.41 (m, 3H), 7.39-7.35 (m, 2H), 7.33-7.30 (m, 2H), 7.17-7.13 (m, 1H), 4.35 (qd, $J=7.1,0.8 \mathrm{~Hz}, 2 \mathrm{H}), 1.31$ (t, $J=7.1 \mathrm{~Hz}, 3 \mathrm{H}) .{ }^{13} \mathbf{C} \mathbf{~ N M R}\left(\mathbf{1 0 1} \mathbf{~ M H z}, \mathbf{C D C l}_{3}\right): \delta 164.6$, 159.1, 137.0, 131.2, 130.1, 129.2, 129.0, 125.6, 125.5, 114.6, 97.0, 63.3, 14.1.

\subsection{7. ethyl 3-oxo-2-phenyl-4-(p-tolyl)-1,2-oxazetidine-4-carboxylate (5b):}

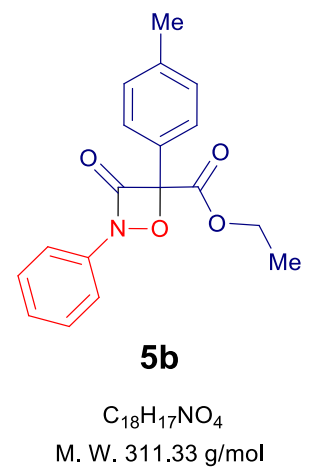

According to GP-11 compound $\mathbf{5 b}$ was prepared by using $\mathbf{4 b}(46.0 \mathrm{mg}, 0.2 \mathrm{mmol}, 2.0$ equiv) and $\mathbf{2 a}(11.0 \mathrm{mg}, 0.1$ mmol, 1.0 equiv) in toluene for $3 \mathrm{~h}$ at $\mathrm{rt}$. Column chromatographic purification (petroleum ether/EtOAc 99:1 to 95:5) afforded $\mathbf{5 b}$ as light green oil (19.0 $\mathrm{mg}, 61 \%)$.

HRMS (ESI): $\mathrm{m} / \mathrm{z}[\mathrm{M}+\mathrm{Na}]^{+}$Calculated for $\left[\mathrm{C}_{18} \mathrm{H}_{17} \mathrm{NNaO}_{4}\right]^{+}: 334.1055$; Found::334.1016.

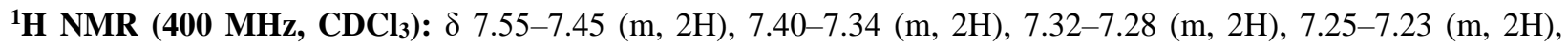
7.17-7.12 (m, 1H), 4.34 (q, $J=7.2 \mathrm{~Hz}, 2 \mathrm{H}), 2.35$ (s, 3H), 1.31 (t, $J=7.2 \mathrm{~Hz}, 3 \mathrm{H}) .{ }^{13} \mathbf{C}$ NMR (101 MHz, CDCl 3$): \delta$ $164.8,159.3,140.3,137.0,129.7,129.2,128.3,125.6,125.4,114.5,97.1,63.2,21.4,14.1$.

\subsection{8. ethyl 4-(4-fluorophenyl)-3-oxo-2-phenyl-1,2-oxazetidine-4-carboxylate (5c):}




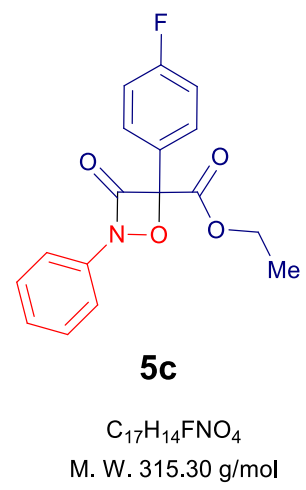

According to GP-11 compound $\mathbf{5 c}$ was prepared by using $\mathbf{4 c}(47.0 \mathrm{mg}, 0.2 \mathrm{mmol}, 2.0$ equiv) and $\mathbf{2 a}(11.0 \mathrm{mg}, 0.1$ mmol, 1.0 equiv) in toluene for $4 \mathrm{~h}$ at rt. Column chromatographic purification (petroleum ether/EtOAc 99:1 to 95:5) afforded $\mathbf{5 c}$ as light green oil (16.0 $\mathrm{mg}, 51 \%)$.

HRMS (ESI): $\mathrm{m} / \mathrm{z}[\mathrm{M}+\mathrm{Na}]^{+}$Calculated for $\left[\mathrm{C}_{17} \mathrm{H}_{14} \mathrm{FNNaO}_{4}\right]^{+}: 338.0805$; Found: 338.0799 .

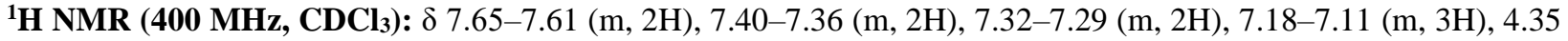
(qd, $J=7.1,0.6 \mathrm{~Hz}, 2 \mathrm{H}), 1.31(\mathrm{t}, J=7.1 \mathrm{~Hz}, 3 \mathrm{H}) .{ }^{13} \mathbf{C}$ NMR (126 MHz, CDCl 3$): \delta$ 164.4, 163.7 (d, $\left.J=249.6 \mathrm{~Hz}\right)$, 158.9, 136.9, 133.1 (d, $J=9.7 \mathrm{~Hz}), 129.3,127.7$ (d, $J=8.8 \mathrm{~Hz}), 125.6,116.2(\mathrm{~d}, J=22.2 \mathrm{~Hz}), 114.6,96.4,63.4$, 14.1. ${ }^{19}$ F NMR: (376 MHz, $\left.\mathbf{C D C l}_{3}\right): \delta-110.33$.

9.19. ethyl 4-(4-bromophenyl)-3-oxo-2-phenyl-1,2-oxazetidine-4-carboxylate (5d):

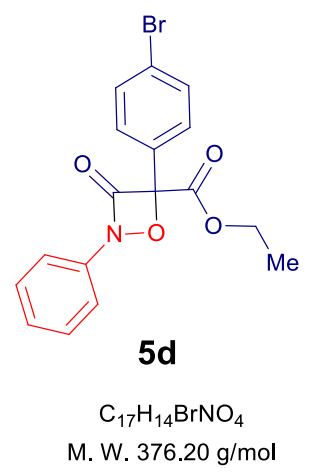

According to GP-11 compound 5d was prepared by using 4d (47.0 mg, $0.2 \mathrm{mmol}, 2.0$ equiv) and 2a (11.0 mg, 0.1 mmol, 1.0 equiv) in toluene for $1.5 \mathrm{~h}$ at $\mathrm{rt}$. Column chromatographic purification (petroleum ether/EtOAc 99:1 to 90:10) afforded $\mathbf{5 d}$ as light yellow oil (18.0 $\mathrm{mg}, 48 \%)$.

HRMS (ESI): $\mathrm{m} / \mathrm{z}[\mathrm{M}+\mathrm{Na}]^{+}$Calculated for $\left[\mathrm{C}_{17} \mathrm{H}_{14} \mathrm{BrNNaO}_{4}\right]^{+}:$398.0004; Found:398.0016.

${ }^{1} \mathbf{H}$ NMR (400 MHz, CDCl $): \delta$ 7.59-7.56 (m, 2H), 7.53-7.51 (m, 2H), 7.39-7.35 (m, 2H), 7.31-7.29 (m, 2H), 7.18-7.14 (m, 1H), $4.34(\mathrm{qd}, J=7.1,0.8 \mathrm{~Hz}, 2 \mathrm{H}), 1.31(\mathrm{t}, J=7.1 \mathrm{~Hz}, 3 \mathrm{H}){ }^{\mathbf{1 3}} \mathbf{C} \mathbf{N M R}(\mathbf{1 2 6} \mathbf{M H z}, \mathbf{C D C l}): \delta 164.2$, $158.7,136.9,132.2,130.2,129.3,127.2,125.7,124.5,114.6,96.4,63.5,14.1$. 
Supplementary Information

9.20. ethyl 3-oxo-4-phenyl-2-(2-(trifluoromethyl)phenyl)-1,2-oxazetidine-4-carboxylate (5e):

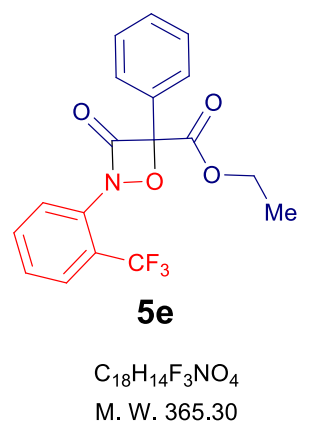

According to GP-11 compound 5e was prepared by using $\mathbf{4 a}(44.0 \mathrm{mg}, 0.2 \mathrm{mmol}, 2.0$ equiv) and $\mathbf{2 f}$ (17.5 $\mathrm{mg}, 0.1$ mmol, 1.0 equiv) in toluene for $1.5 \mathrm{~h}$ at rt. Column chromatographic purification (petroleum ether/EtOAc 99:1 to 97:3) afforded 5e as light green oil (17.0 mg, 47\%).

HRMS (ESI): $\mathrm{m} / \mathrm{z}[\mathrm{M}+\mathrm{Na}]^{+}$Calculated for $\left[\mathrm{C}_{18} \mathrm{H}_{14} \mathrm{NNaO}_{4}\right]^{+}: 388.0773$; Found:388.0762

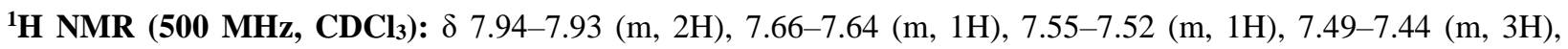
$7.22-7.19(\mathrm{~m}, 1 \mathrm{H}), 6.88-6.86(\mathrm{~m}, 1 \mathrm{H}), 4.09$ (q, $J=7.1 \mathrm{~Hz}, 2 \mathrm{H}), 0.93(\mathrm{t}, J=7.1 \mathrm{~Hz}, 3 \mathrm{H}) .{ }^{13} \mathbf{C}$ NMR (126 MHz, $\left.\mathbf{C D C l}_{3}\right): \delta 164.0,160.7,148.3,133.5,132.4,132.3,128.9,128.5,126.4(\mathrm{q}, J=5.2 \mathrm{~Hz}), 124.9,124.4,119.6,103.2$, 61.6, 13.7. ${ }^{19}$ F NMR: $\left(376 \mathbf{M H z}, \mathbf{C D C l}_{3}\right): \delta-61.41$.

\subsection{1. ethyl 2-(2-cyanophenyl)-3-oxo-4-phenyl-1,2-oxazetidine-4-carboxylate (5f):}

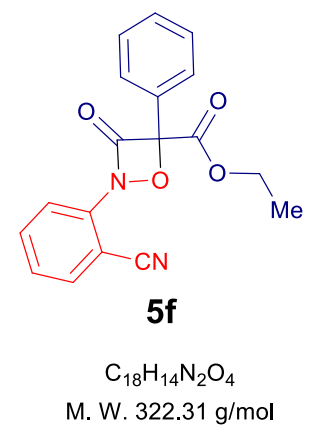

According to GP-11 compound $\mathbf{5 f}$ was prepared by using $\mathbf{4 a}(44.0 \mathrm{mg}, 0.2 \mathrm{mmol}, 2.0$ equiv) and $\mathbf{2 g}$ (13.0 $\mathrm{mg}, 0.1$ mmol, 1.0 equiv) in toluene for $2 \mathrm{~h}$ at $\mathrm{rt}$. Column chromatographic purification (petroleum ether/EtOAc 99:1 to $85: 15)$ afforded $\mathbf{5 f}$ as light yellow oil (18.0 $\mathrm{mg}, 56 \%)$.

HRMS (ESI): $\mathrm{m} / \mathrm{z}[\mathrm{M}+\mathrm{H}]^{+}$Calculated for $\left[\mathrm{C}_{18} \mathrm{H}_{15} \mathrm{~N}_{2} \mathrm{O}_{4}\right]^{+}: 323.1032$; Found: 323.1019. 
Supplementary Information

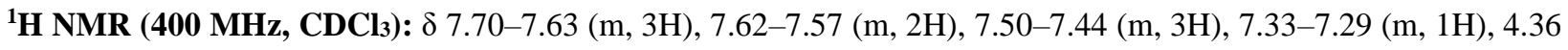
(q, $J=7.1 \mathrm{~Hz}, 2 \mathrm{H}), 1.32$ (t, $J=7.1 \mathrm{~Hz}, 3 \mathrm{H}) .{ }^{13} \mathbf{C} \mathbf{N M R}\left(\mathbf{1 0 1} \mathbf{M H z}, \mathbf{C D C l}_{3}\right): \delta 164.0,160.1,139.1,134.2,133.8$, $130.7,130.2,129.1,126.7,125.5,118.6,115.9,102.2,98.3,63.6,14.1$.

\subsection{2,4-diphenyl-1,2-oxazetidin-3-one (5g):}

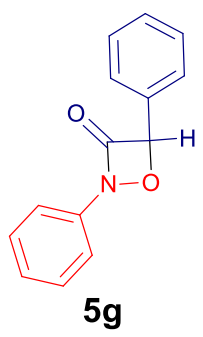

$\mathrm{C}_{14} \mathrm{H}_{11} \mathrm{NO}_{2}$

M. W. $225.24 \mathrm{~g} / \mathrm{mol}$

According to GP-11 compound $\mathbf{5 g}$ was prepared by using $\mathbf{4 e}(29.0 \mathrm{mg}, 0.2 \mathrm{mmol}, 2.0$ equiv) and $\mathbf{2 a}$ (11.0 $\mathrm{mg}, 0.1$ mmol, 1.0 equiv) in toluene for $1.5 \mathrm{~h}$ at rt. Column chromatographic purification (petroleum ether/EtOAc 99:1 to 95:5) afforded $\mathbf{5 g}$ as colourless oil (7.0 $\mathrm{mg}, 31 \%)$.

Alternatively, compound $\mathbf{5 g}$ was prepared according to $\mathbf{G P - 1 1}$ by using $\mathbf{4 f}$ (38.0 $\mathrm{mg}, 0.2 \mathrm{mmol}, 2.0$ equiv) and 2a (11.0 $\mathrm{mg}, 0.1 \mathrm{mmol}, 1.0$ equiv) in toluene for $1.5 \mathrm{~h}$ at $\mathrm{rt}$. Column chromatographic purification (petroleum ether/EtOAc 99:1 to 95:5) afforded $\mathbf{5 g}$ as colourless oil (11.0 $\mathrm{mg}, 49 \%)$.

HRMS (ESI): $\mathrm{m} / \mathrm{z}[\mathrm{M}+\mathrm{Na}]^{+}$Calculated for $\left[\mathrm{C}_{14} \mathrm{H}_{11} \mathrm{NNaO}_{2}\right]^{+}: 248.0687$; Found:.248.0679.

${ }^{1} \mathbf{H}$ NMR (400 MHz, CDCl $)$ ): $\delta$ 7.50-7.48 (m, 2H), 7.46-7.42 (m, 3H), 7.40-7.38 (m, 2H), 7.34-7.32 (m, 2H), 7.18-7.14 (m, 1H), 6.35 (s, 1H). ${ }^{13} \mathbf{C}$ NMR (126 MHz, CDCl3): $\delta 162.7,137.3,131.4,130.2,129.1,129.1,127.3$, 124.9, 114.1, 92.7 .

\subsection{2-phenyl-4-(p-tolyl)-1,2-oxazetidin-3-one (5h):}

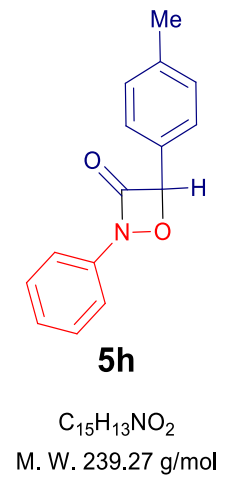


Supplementary Information

According to GP-11 compound $\mathbf{5 h}$ was prepared by using $\mathbf{4 g}$ (40.0 mg, $0.2 \mathrm{mmol}, 2.0$ equiv) and $\mathbf{2 a}(11.0 \mathrm{mg}, 0.1$ mmol, 1.0 equiv) in toluene for $1.5 \mathrm{~h}$ at rt. Column chromatographic purification (petroleum ether/EtOAc 99:1 to 95:5) afforded $\mathbf{5 h}$ as colourless oil (12.0 $\mathrm{mg}, 50 \%)$.

HRMS (ESI): $\mathrm{m} / \mathrm{z}[\mathrm{M}+\mathrm{Na}]^{+}$Calculated for $\left[\mathrm{C}_{15} \mathrm{H}_{13} \mathrm{NNaO}_{2}\right]^{+}: 262.0844$; Found:.262.0858

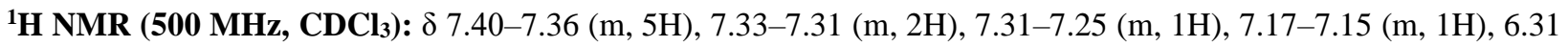
(s, 1H), 2.37 (s, 3H). ${ }^{13} \mathbf{C}$ NMR (126 MHz, CDCl $): \delta 162.9,140.6,137.3,129.9,129.2,128.5,127.6,124.8,114.1$, 92.8, 21.5.

\subsection{4-methyl-2,4-diphenyl-1,2-oxazetidin-3-one (5i):}

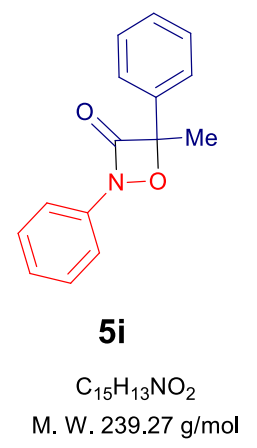

According to GP-10 compound $\mathbf{5 i}$ was prepared by using $\mathbf{4 h}(32.0 \mathrm{mg}, 0.2 \mathrm{mmol}, 2.0$ equiv) and $\mathbf{2 a}(11.0 \mathrm{mg}, 0.1$ mmol, 1.0 equiv) in $\mathrm{CH}_{2} \mathrm{Cl}_{2}$ for $10 \mathrm{~h}$ at rt. Column chromatographic purification (petroleum ether/EtOAc 99:1 to 97:3) afforded $\mathbf{5 i}$ as light yellow oil (17.0 $\mathrm{mg}, 71 \%)$.

HRMS (ESI): $\mathrm{m} / \mathrm{z}[\mathrm{M}+\mathrm{H}]^{+}$Calculated for $\left[\mathrm{C}_{15} \mathrm{H}_{14} \mathrm{NO}_{2}\right]^{+}: 240.1025$; Found: 240.1021 .

${ }^{1}$ H NMR (400 MHz, CDCl$)$ : $\delta$ 7.56-7.53 (m, 2H), 7.44-7.40 (m, 2H), 7.39-7.35 (m, 3H), 7.32-7.29 (m, 2H), 7.15-7.11 (m, 1H), 2.04 (s, 3H). ${ }^{13} \mathbf{C}$ NMR (101 MHz, CDCl $): \delta 165.2,137.4,136.4,129.2,129.1,128.9,124.9$, 124.7, 114.1, 98.5, 22.4.

9.25. methyl 3-oxo-2-phenyl-4-(thiophen-2-yl)-1,2-oxazetidine-4-carboxylate (5j):

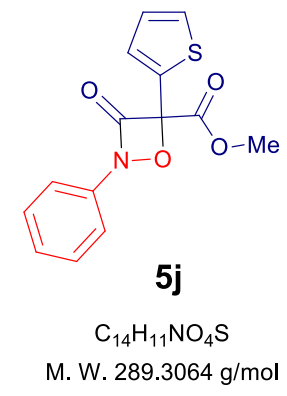


Supplementary Information

According to GP-11 compound 5j was prepared by using $\mathbf{4 k}$ (42.0 mg, $0.2 \mathrm{mmol}, 2.0$ equiv) and $\mathbf{2 a}(11.0 \mathrm{mg}, 0.1$ mmol, 1.0 equiv) in toluene for $4 \mathrm{~h}$ at $\mathrm{rt}$. Column chromatographic purification (petroleum ether/EtOAc 99:1 to 97:3) afforded $\mathbf{5 j}$ as green oil (12.5 $\mathrm{mg}, 43 \%)$.

HRMS (ESI): $\mathrm{m} / \mathrm{z}[\mathrm{M}+\mathrm{Na}]^{+}$Calculated for $\left[\mathrm{C}_{14} \mathrm{H}_{11} \mathrm{NNaO}_{4} \mathrm{~S}\right]^{+}: 312.0306$; Found:.312.0311

${ }^{1} \mathbf{H}$ NMR (400 MHz, CDCl $\delta 7.54(\mathrm{dd}, J=5.0,0.9,1 \mathrm{H}), 7.42$ (dd, J=3.7, 0.9, 1H), 7.33-7.29 (m, 2H), 7.15-7.09 (m, 2H), 6.96-6.94 (m, 2H), 3.64 (s, 3H). ${ }^{13} \mathbf{C}$ NMR (101 MHz, CDCl3): $\delta$ 164.5, 154.0, 149.5, 140.6, 131.7, 131.6, 129.0, 128.0, 125.3, 119.9, 118.6, 52.4.

\subsection{6. ethyl 3-hydroxy-2-phenyl-2-((phenylamino)oxy)propanoate (6a):}

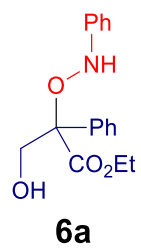

$\mathrm{C}_{17} \mathrm{H}_{19} \mathrm{NO}_{4}$

M. W. 301.34

According to GP-12 compound 6a was prepared by using $\mathbf{5 a}\left(15.0 \mathrm{mg}, 0.05 \mathrm{mmol}, 1.0\right.$ equiv) and $\mathrm{NaBH}_{4}(8.0 \mathrm{mg}$, $0.2 \mathrm{mmol}, 4.0$ equiv) in $\mathrm{EtOH}$ for $0.5 \mathrm{~h}$ at $0{ }^{\circ} \mathrm{C}$. Column chromatographic purification (petroleum ether/EtOAc 97:3 to $85: 15)$ afforded $\mathbf{6 a}$ as colourless liquid (12.0 $\mathrm{mg}, 80 \%)$.

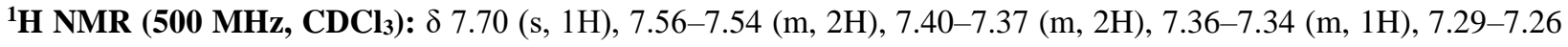
(m, 2H), 7.11-7.09 (m, 2H), 7.03-7.00 (m, 1H), $4.45(\mathrm{~d}, J=12.4 \mathrm{~Hz}, 1 \mathrm{H}), 4.34(\mathrm{~d}, J=12.3 \mathrm{~Hz}, 1 \mathrm{H}), 4.29(\mathrm{qd}, J=$ 7.1, 3.3 Hz, 2H), $1.25(\mathrm{t}, J=7.1 \mathrm{~Hz}, 3 \mathrm{H}) .{ }^{13} \mathbf{C}$ NMR (126 MHz, $\left.\mathbf{C D C l}_{3}\right): \delta 171.2,147.5,136.0,129.1,128.8,128.7$, $126.1,123.2,115.9,88.2,67.8,61.9,14.1$.

HRMS (ESI): $\mathrm{m} / \mathrm{z}[\mathrm{M}+\mathrm{Na}]^{+}$Calculated for $\left[\mathrm{C}_{17} \mathrm{H}_{19} \mathrm{NNaO}_{4}\right]^{+}: 324.1212$; Found: 324.1201.

\subsection{2-phenyl-2-((phenylamino)oxy)propane-1,3-diol (6b):}

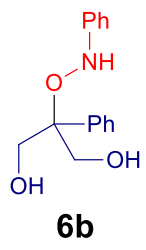

$\mathrm{C}_{15} \mathrm{H}_{17} \mathrm{NO}_{3}$

M. W. 259.30 
Supplementary Information

According to GP-13 compound $\mathbf{6 b}$ was prepared by using $\mathbf{5 a}\left(15.0 \mathrm{mg}, 0.05 \mathrm{mmol}, 1.0\right.$ equiv) and $\mathrm{NaBH}_{4}(19.0 \mathrm{mg}$, $0.5 \mathrm{mmol}, 10.0$ equiv) in $\mathrm{EtOH}$ for $3 \mathrm{~h}$ at $0{ }^{\circ} \mathrm{C}$. Column chromatographic purification (petroleum ether/EtOAc 97:3 to $80: 20$ ) afforded $\mathbf{6 b}$ as colourless liquid (10.0 $\mathrm{mg}, 77 \%)$.

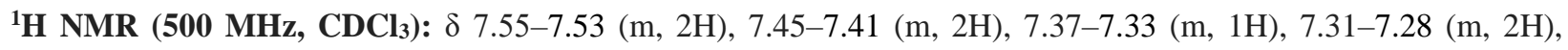
7.11-7.10 (m, 2H), 7.04-7.01 (m, 1H), 6.95 (s, 1H), 4.18 (s, 4H), 2.62 (br s, 2H). ${ }^{13} \mathbf{C}$ NMR (126 MHz, CDCl 3$): \delta$ $147.7,138.7,129.2,129.0,128.2,126.5,123.3,115.8,85.8,67.2$.

HRMS (ESI): $\mathrm{m} / \mathrm{z}[\mathrm{M}+\mathrm{Na}]^{+}$Calculated for $\left[\mathrm{C}_{15} \mathrm{H}_{17} \mathrm{NNaO}_{3}\right]^{+}: 282.1106$; Found: .282.1116.

\subsection{8. ethyl 2-hydroxy-3-oxo-2-phenyl-3-(phenylamino)propanoate (6c):}

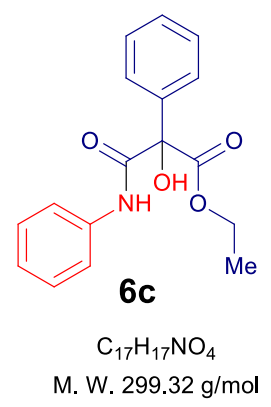

According to GP-14 compound 6c was prepared by using 5a (15.0 mg, $0.05 \mathrm{mmol}, 1.0$ equiv) and Zinc powder ( $16.0 \mathrm{mg}, 0.25 \mathrm{mmol}, 5$ equiv) in DCM. To this suspension was added acetic acid ( $14 \mu \mathrm{L}, 0.25 \mathrm{mmol}, 5$ equiv) portionwise over $3 \mathrm{~h}$. The mixture was stirred for an additional $3 \mathrm{~h}$ at r.t., and then the solids were removed by filtration through Celite. The filtrate was concentrated under reduced pressure. Column chromatographic purification (petroleum ether/EtOAc 95:5 to 75:25) afforded $\mathbf{6 c}$ as colourless liquid (12.5 $\mathrm{mg}, 84 \%$ ).

${ }^{1} \mathrm{H}$ NMR (400 MHz, $\left.\mathbf{C D C l}_{3}\right): \delta 8.90$ (br s, 1H), 7.77-7.75 (m, 2H), 7.55-7.53 (m, 2H), 7.41-7.30 (m, 5H), 7.14$7.10(\mathrm{~m}, 1 \mathrm{H}), 4.98(\mathrm{br} \mathrm{s}, 1 \mathrm{H}), 4.42-4.31(\mathrm{~m}, 2 \mathrm{H}), 1.34(\mathrm{t}, \mathrm{J}=7.2 \mathrm{~Hz}, 4 \mathrm{H}) .{ }^{13} \mathbf{C}$ NMR (126 MHz, CDCl$)$ ): $\delta$ 171.3, 166.2, 137.3, 137.0, 129.1, 128.8, 128.4, 126.1, 124.9, 119.8, 80.0, 64.0, 14.0.

HRMS (ESI): $\mathrm{m} / \mathrm{z}[\mathrm{M}+\mathrm{Na}]^{+}$Calculated for $\left[\mathrm{C}_{17} \mathrm{H}_{17} \mathrm{NNaO}_{4}\right]^{+}: 322.1055$; Found: . 322.1064. 
Supplementary Information

\section{NMR Spectra:}

10.1. methyl 2-oxo-2-phenylacetate (3a):
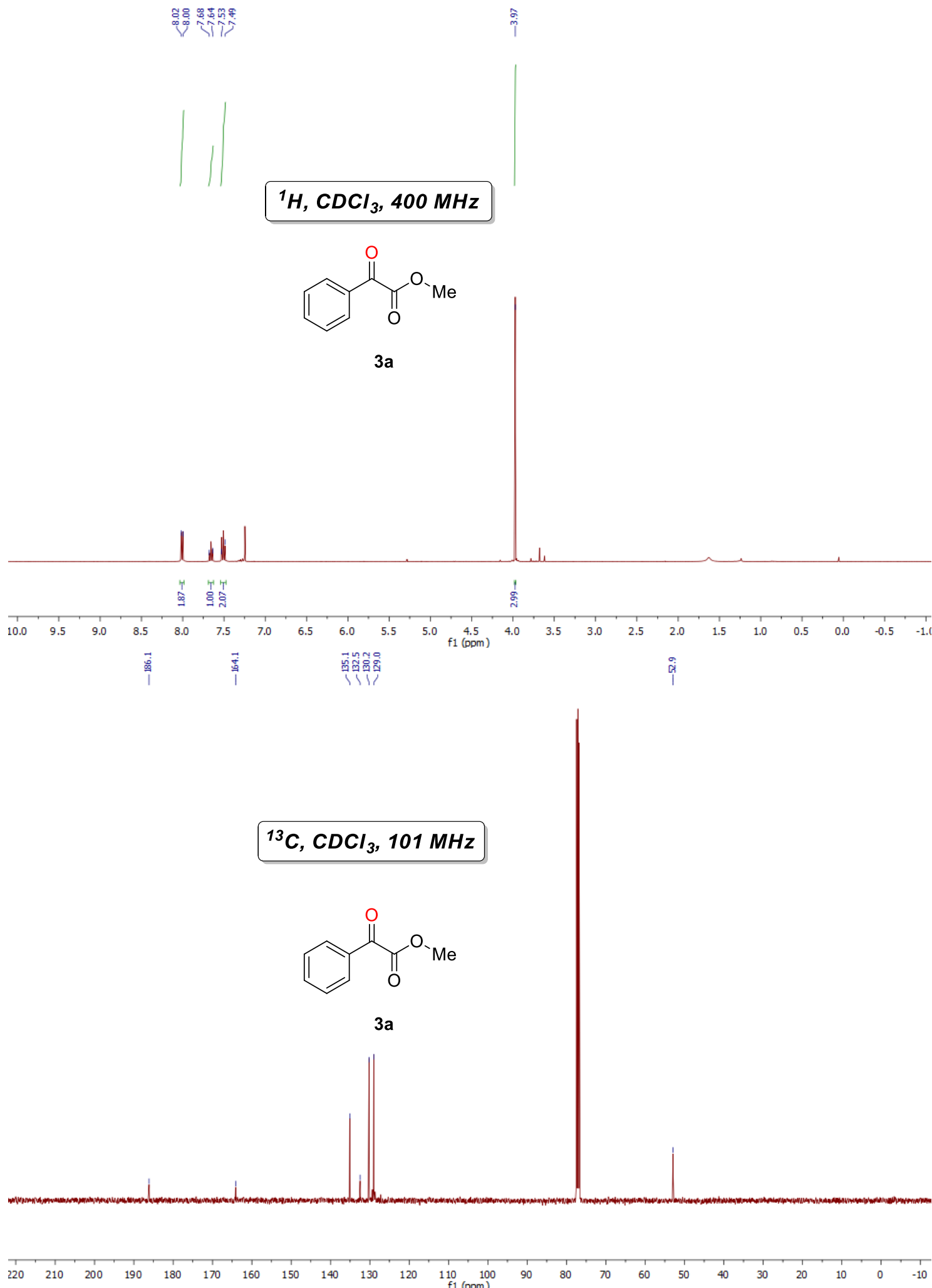
Supplementary Information

10.2. methyl 2-(4-methoxyphenyl)-2-oxoacetate (3b):

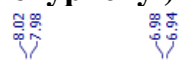
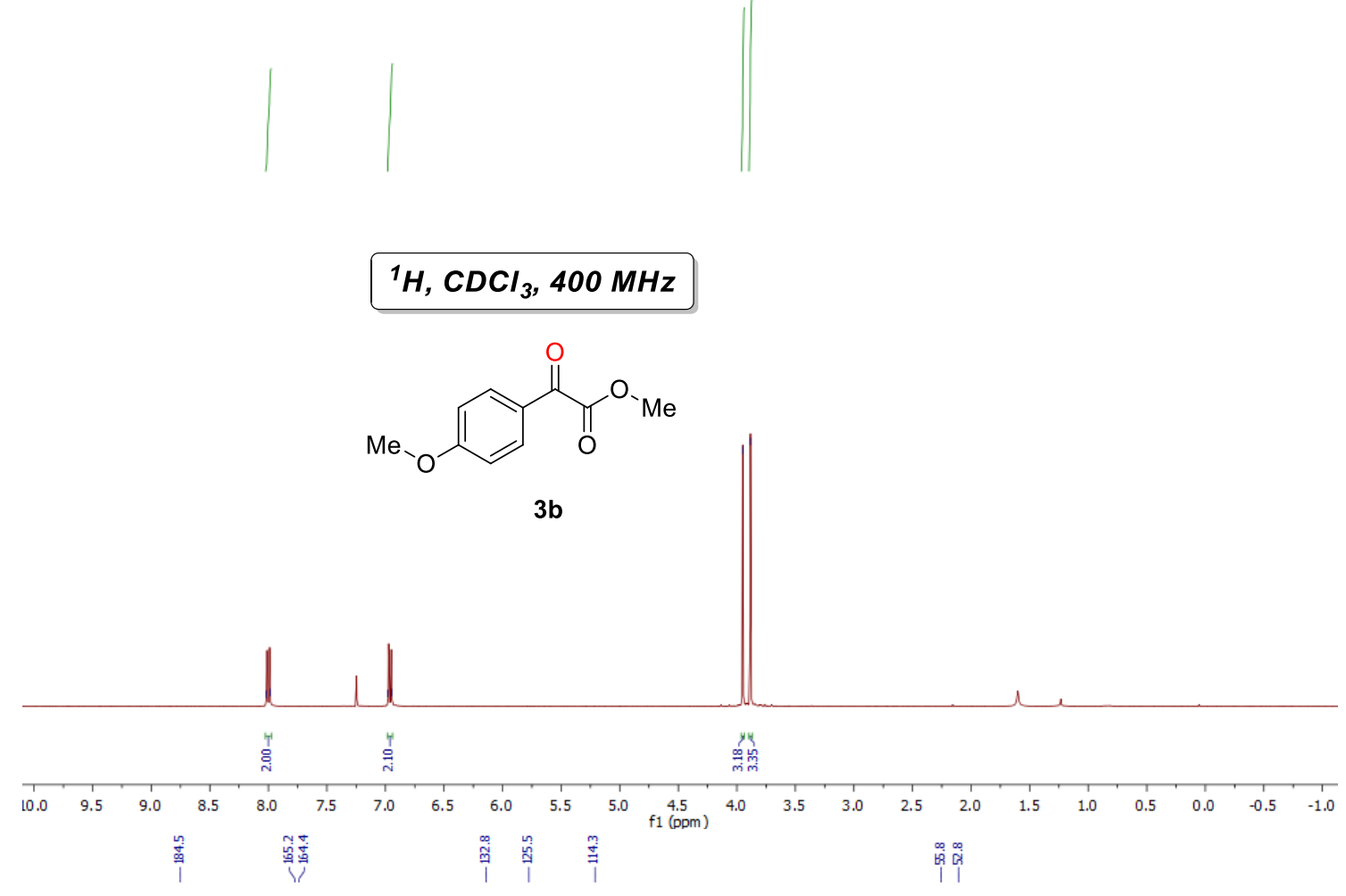

${ }^{13} \mathrm{C}, \mathrm{CDCl}_{3}, 101 \mathrm{MHz}$

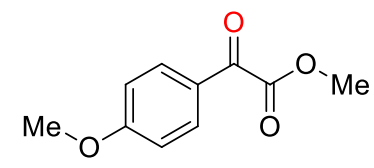

3b

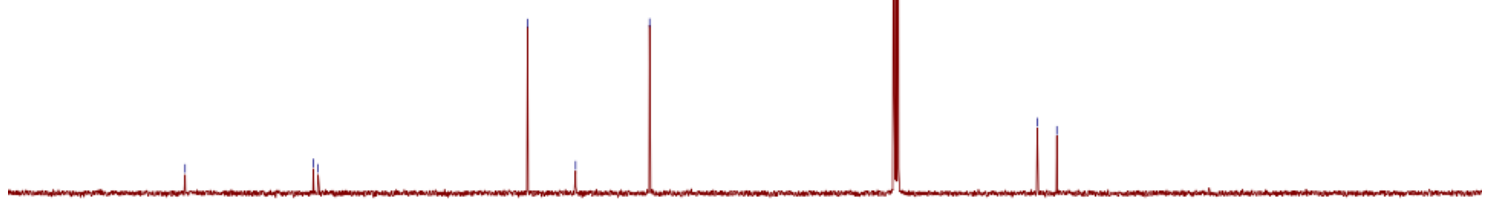

$\begin{array}{lllllllllllllllllllllllllllll}110 & 200 & 190 & 180 & 170 & 160 & 150 & 140 & 130 & 120 & 110 & 100 & 90 & 80 & 70 & 60 & 50 & 40 & 30 & 20 & 10 & 0 & -10\end{array}$ 
Supplementary Information

10.3. methyl 2-(4-fluorophenyl)-2-oxoacetate (3c):

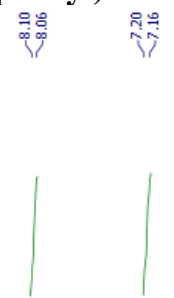

${ }^{1} \mathrm{H}, \mathrm{CDCl}_{3}, 400 \mathrm{MHz}$

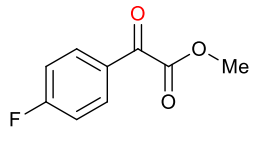

3c

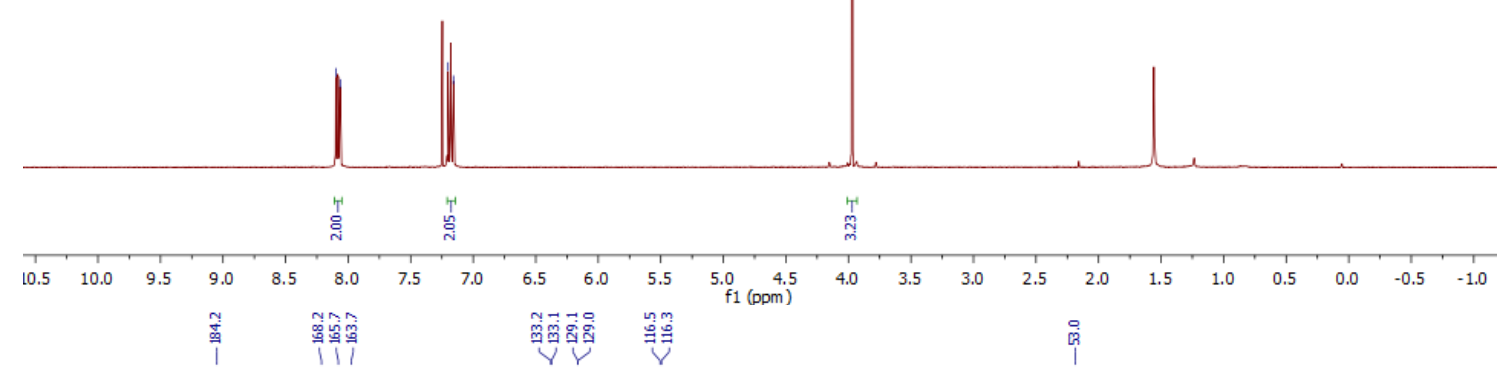

${ }^{13} \mathrm{C}_{, \mathrm{CDCl}_{3}, 101 \mathrm{MHz}}$

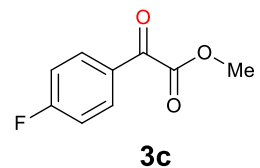

3c

$\left.\begin{array}{llllllllllll}210 & 200 & 190 & 180 & 170 & 160 & 150 & 140 & 130 & 120 & 110 & 100 \\ \mathrm{f} 1(\mathrm{ppm})\end{array}\right)$ 
Supplementary Information

${ }^{19} \mathrm{~F}, \mathrm{CDCl}_{3}, 376 \mathrm{MHz}$

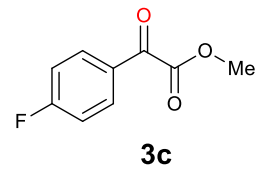

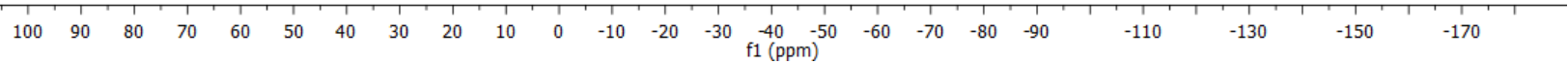


Supplementary Information

10.4. methyl 2-(4-chlorophenyl)-2-oxoacetate (3d):

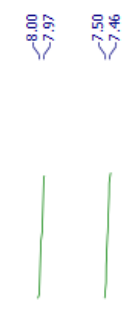

\section{${ }^{1} \mathrm{H}, \mathrm{CDCl}_{3}, 400 \mathrm{MHz}$}<smiles>COC(=O)C(=O)c1ccc(Cl)cc1</smiles>

3d

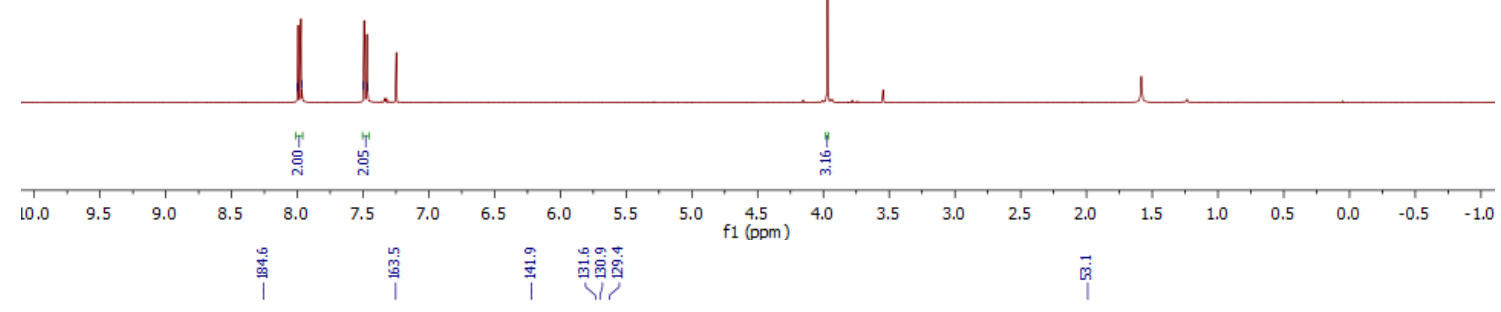

\section{${ }^{13} \mathrm{C}, \mathrm{CDCl}_{3}, 101 \mathrm{MHz}$}<smiles>COC(=O)C(=O)c1ccc(Cl)cc1</smiles>

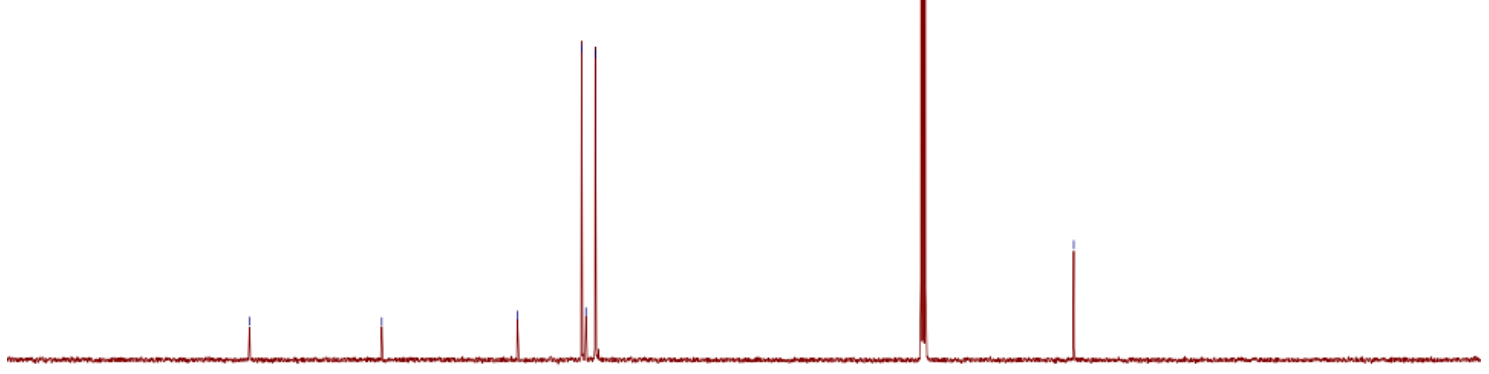

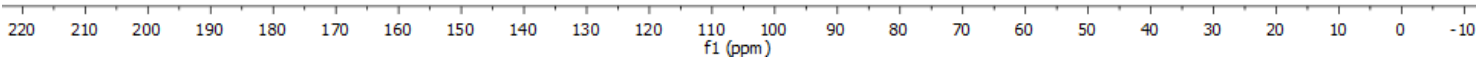


Supplementary Information

10.5. methyl 2-(2-bromophenyl)-2-oxoacetate (3e):

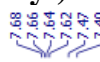

${ }^{1} \mathrm{H}, \mathrm{CDCl}_{3}, 400 \mathrm{MHz}$<smiles>COC(=O)C(=O)c1ccccc1Br</smiles>

3e

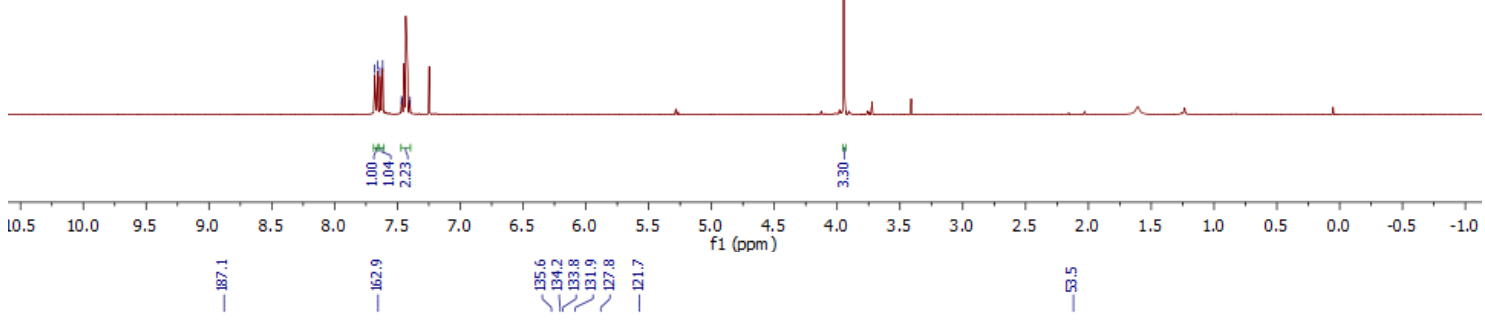

${ }^{13} \mathrm{C} \mathrm{CDCl}_{3}, 101 \mathrm{MHz}$

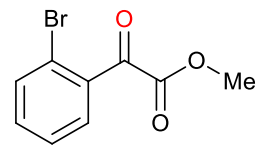

$3 e$
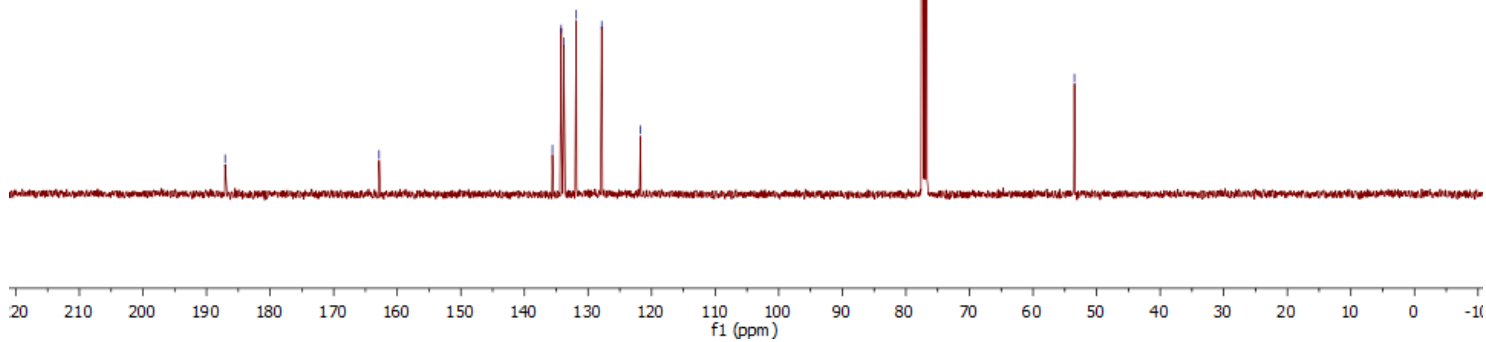
Supplementary Information

10.6. methyl 2-(naphthalen-2-yl)-2-oxoacetate (3f):

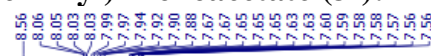

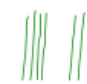

${ }^{1} \mathrm{H}, \mathrm{CDCl}_{3}, 400 \mathrm{MHz}$<smiles>COC(=O)C(=O)c1ccc2ccccc2c1</smiles>

$3 f$
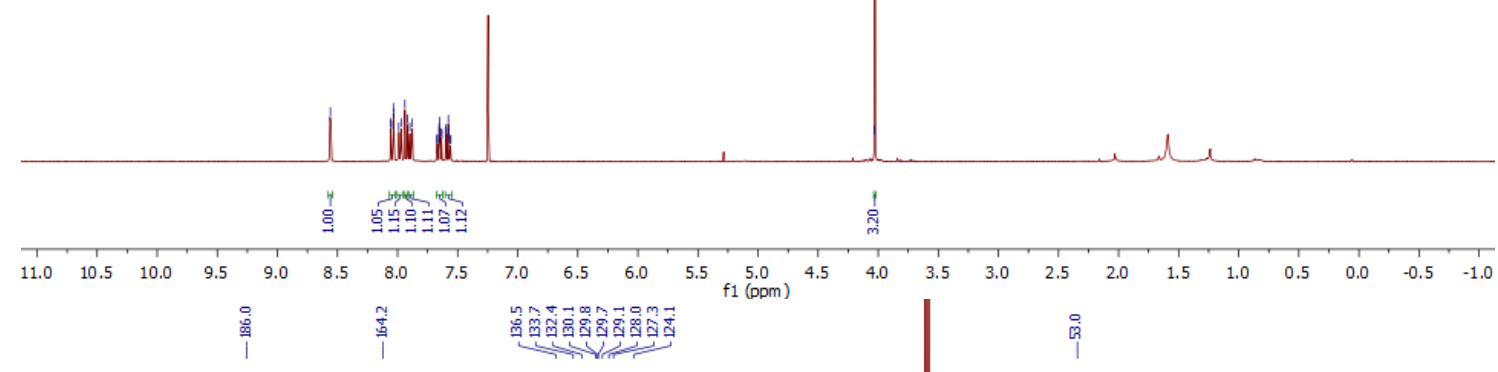

${ }^{13} \mathrm{C}, \mathrm{CDCl}_{3}, 101 \mathrm{MHz}$

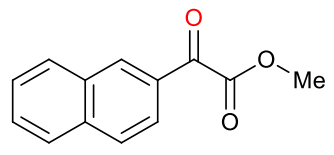

$3 f$

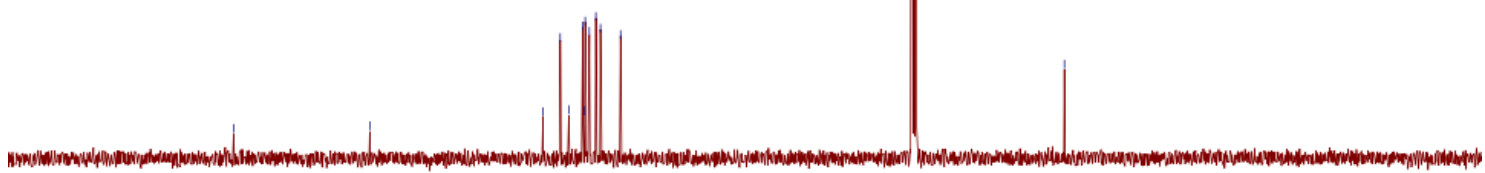

$\begin{array}{llllllllllllllllllllllllllllllllll}220 & 210 & 200 & 190 & 180 & 170 & 160 & 150 & 140 & 130 & 120 & 110 & 100 & 90 & 80 & 70 & 60 & 50 & 40 & 30 & 20 & 10 & 0 & -10\end{array}$ 
Supplementary Information

10.7. ethyl 2-oxo-2-phenylacetate (3g): 至密
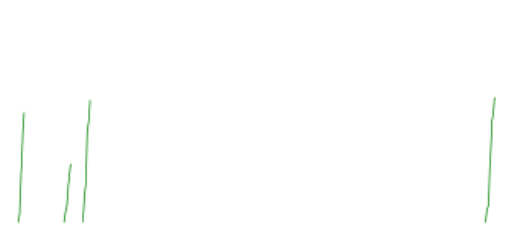

${ }^{1} \mathrm{H}, \mathrm{CDCl}_{3}, 400 \mathrm{MHz}$<smiles>CCOC(=O)C(=O)c1ccccc1</smiles>

$3 \mathrm{~g}$

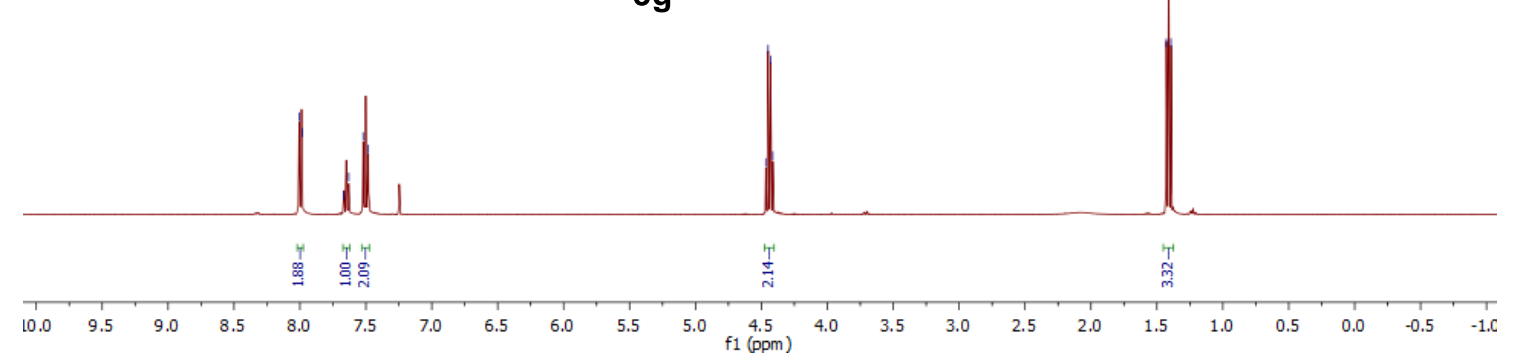

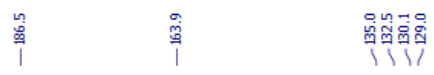

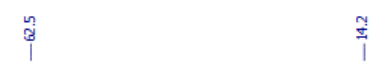

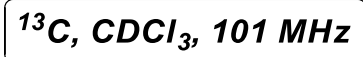

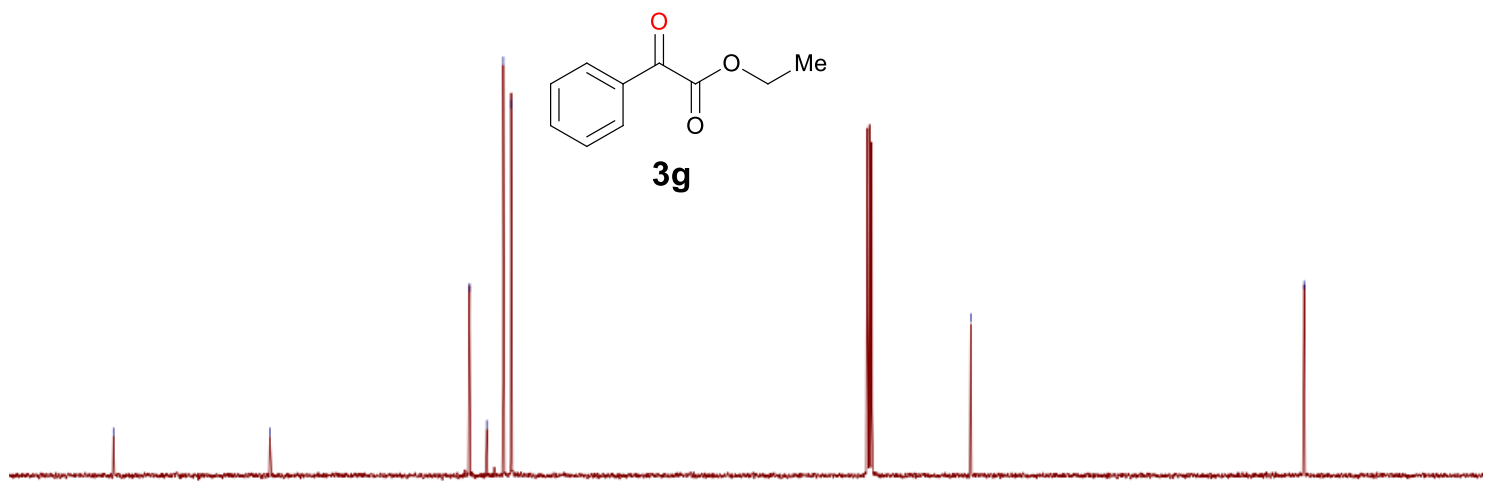

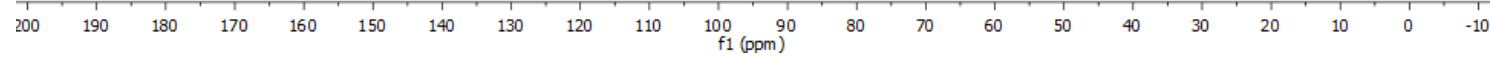


Supplementary Information

10.8. ethyl 2-oxo-2-(o-tolyl)acetate (3h):

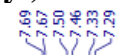

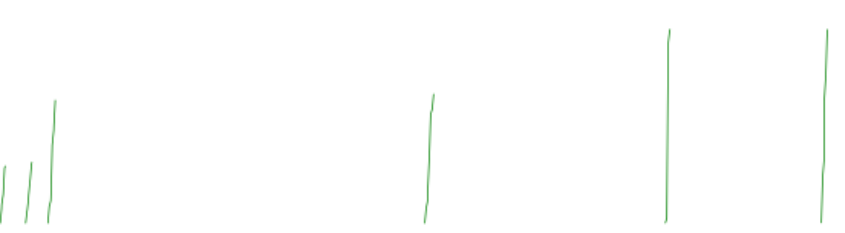

\section{${ }^{1} \mathrm{H}, \mathrm{CDCl}_{3}, 400 \mathrm{MHz}$}<smiles>C[N+](=O)COC(=O)C(=O)c1ccccc1[N+](=O)[O-]</smiles>

3h
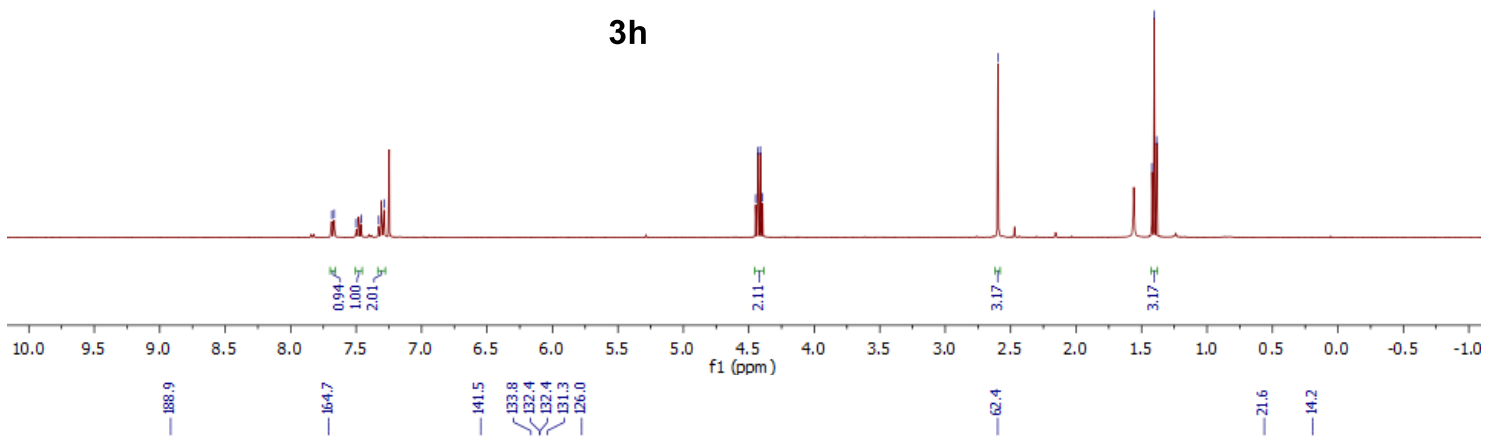

${ }^{13} \mathrm{C}_{1} \mathrm{CDCl}_{3}, 101 \mathrm{MHz}$

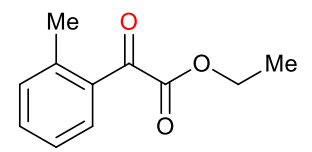

3h
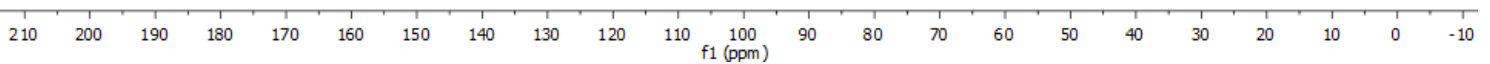
Supplementary Information

10.9. isopropyl 2-oxo-2-phenylacetate (3i): gag

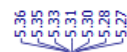

巽禹

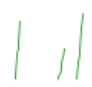

${ }^{1} \mathrm{H}, \mathrm{CDCl}_{3}, 400 \mathrm{MHz}$

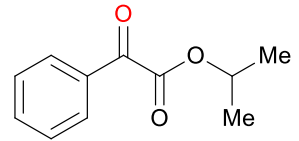

$3 \mathbf{i}$

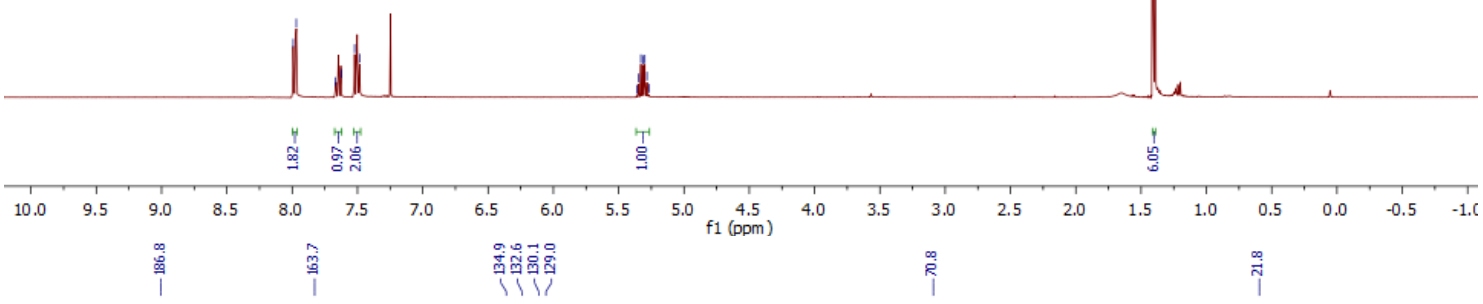

${ }^{13} \mathrm{C}_{,} \mathrm{CDCl}_{3}, 101 \mathrm{MHz}$

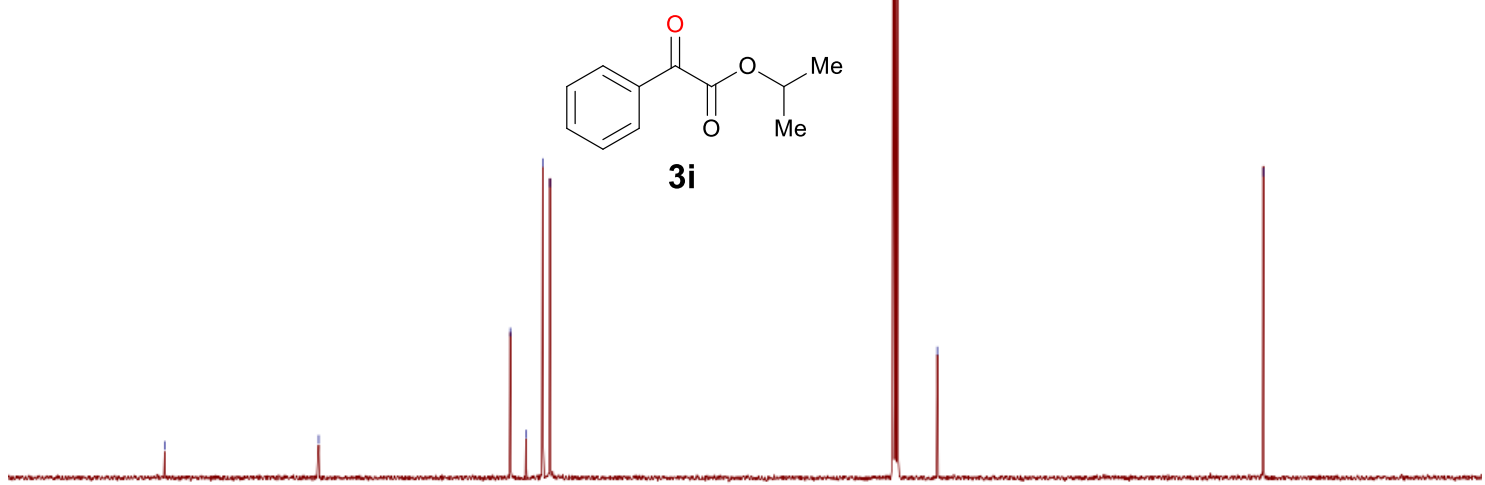

$\begin{array}{lllllllllllllllllllllllll}10 & 200 & 190 & 180 & 170 & 160 & 150 & 140 & 130 & 120 & 110 & 100 & 90 & 80 & 70 & 60 & 50 & 40 & 30 & 20 & 10 & 0 & -10\end{array}$ 
Supplementary Information

10.10. benzyl 2-oxo-2-phenylacetate (3j):

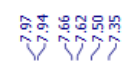

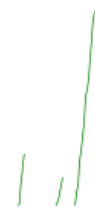

\section{${ }^{1} \mathrm{H}, \mathrm{CDCl}_{3}, 400 \mathrm{MHz}$}

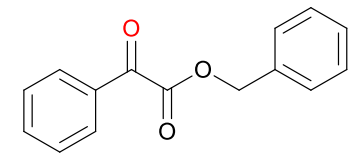

3j

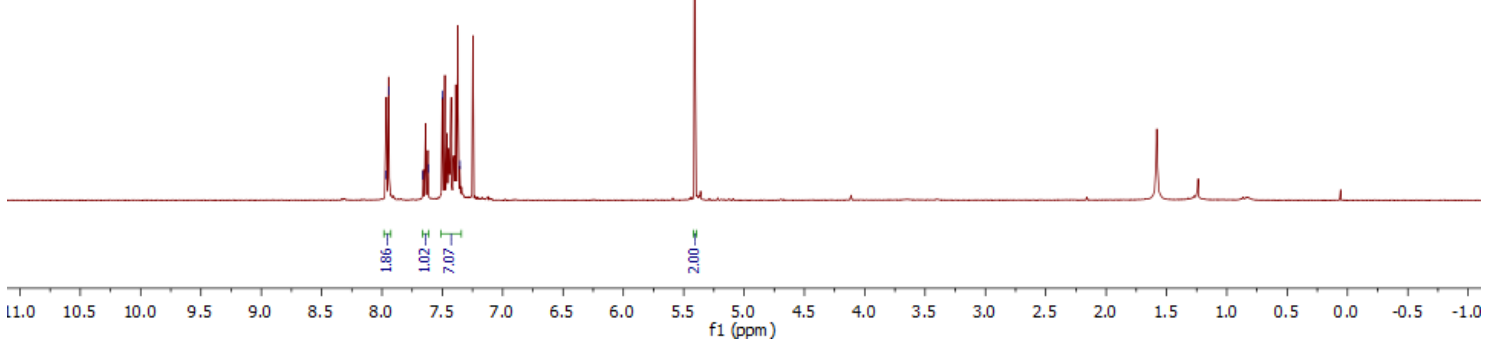

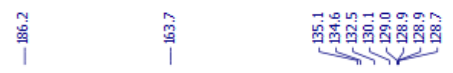

\section{${ }^{13} \mathrm{C}, \mathrm{CDCl}_{3}, 101 \mathrm{MHz}$}

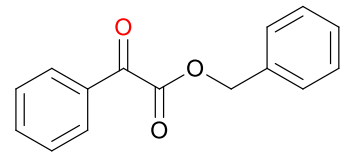

3j
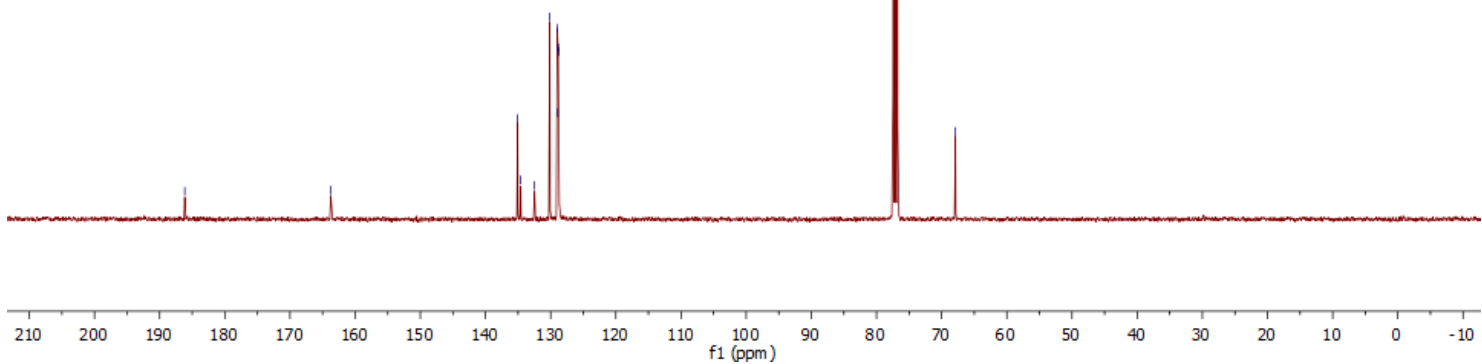
Supplementary Information

10.11. allyl 2-oxo-2-phenylacetate (3k):

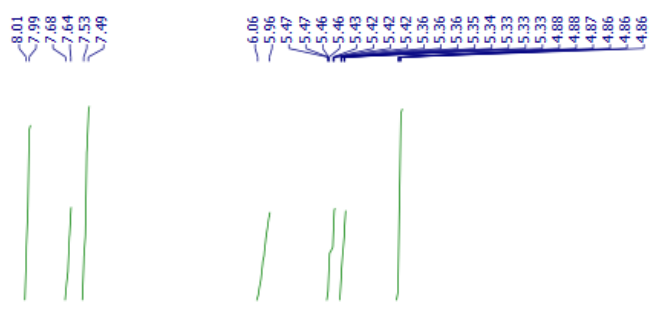

${ }^{1} \mathrm{H}, \mathrm{CDCl}_{3}, 400 \mathrm{MHz}$

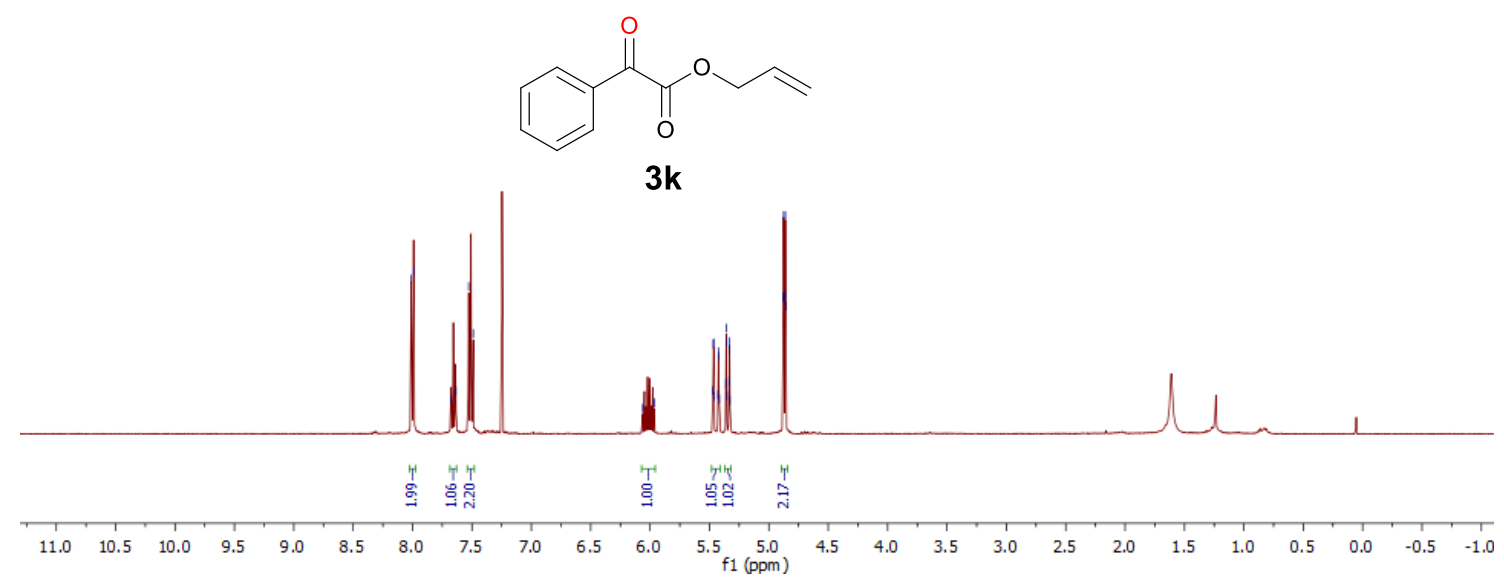

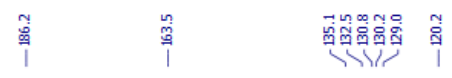

${ }^{13} \mathrm{C}, \mathrm{CDCl}_{3}, 101 \mathrm{MHz}$

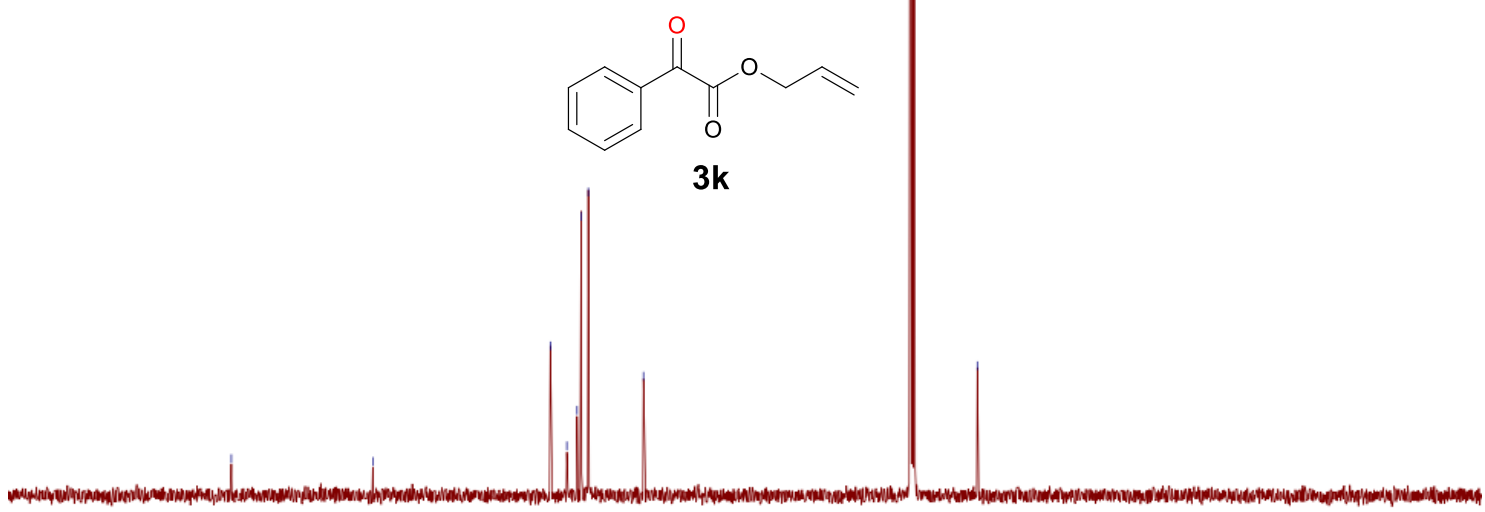

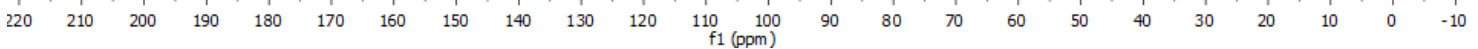


Supplementary Information

10.12. prop-2-yn-1-yl 2-oxo-2-phenylacetate (31):

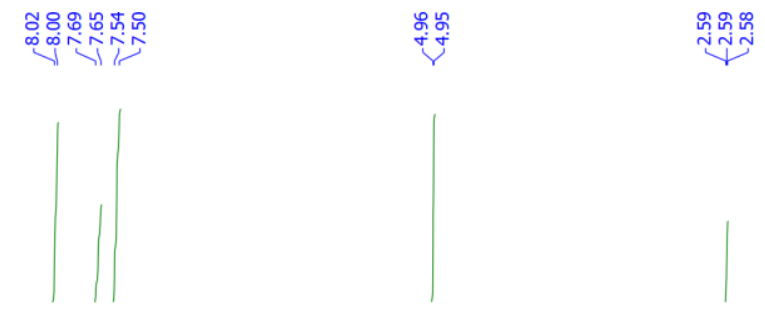

${ }^{1} \mathrm{H}, \mathrm{CDCl}_{3}, 400 \mathrm{MHz}$

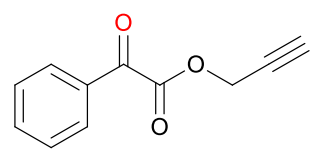

3।

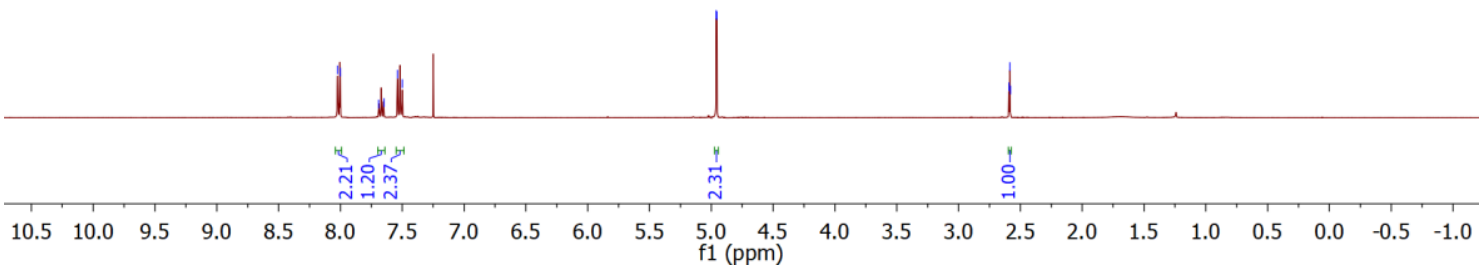

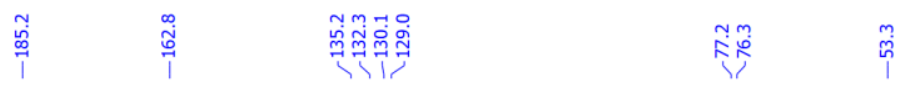

${ }^{13} \mathrm{C}, \mathrm{CDCl}_{3}, 126 \mathrm{MHz}$

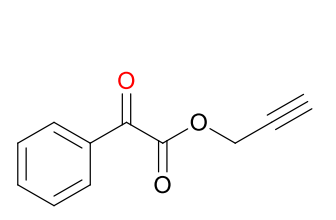

31
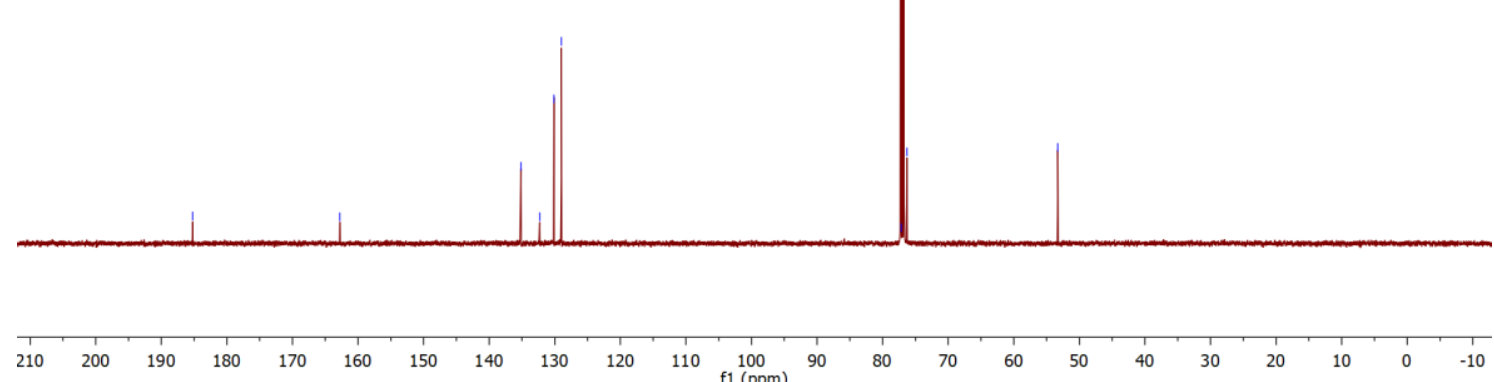
Supplementary Information

10.13. (1R,2S,5R)-2-isopropyl-5-methylcyclohexyl 2-oxo-2-phenylacetate (3m):

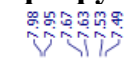

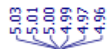

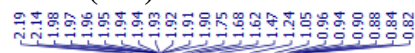
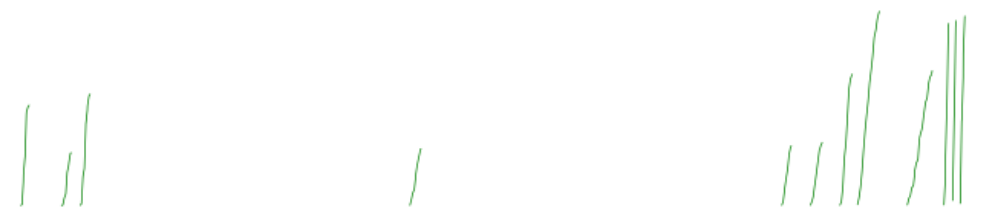

${ }^{1} \mathrm{H}, \mathrm{CDCl}_{3}, 400 \mathrm{MHz}$

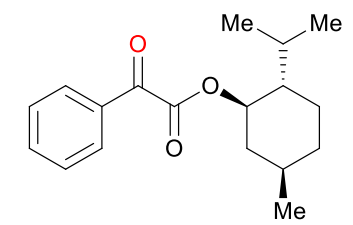

$3 m$

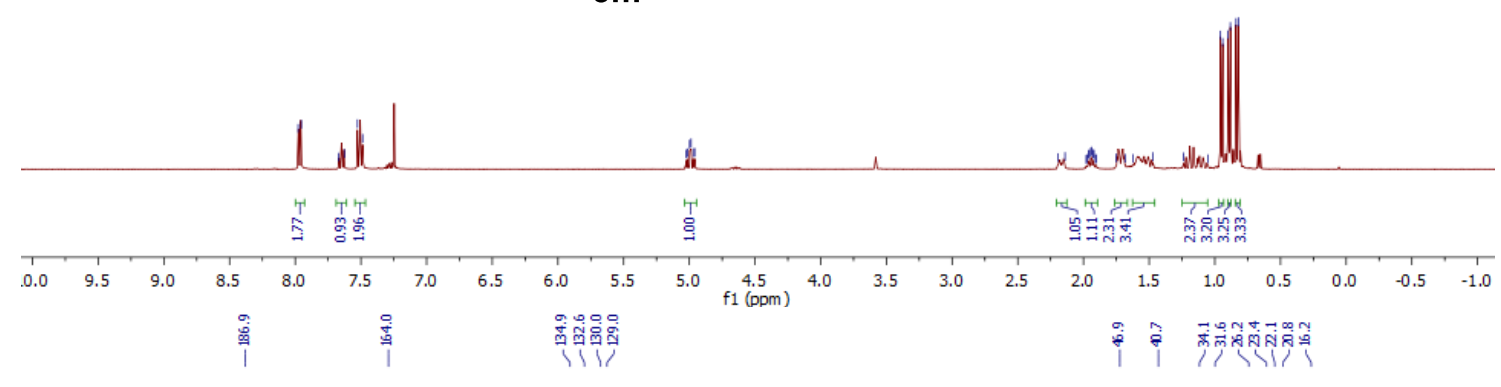

${ }^{13} \mathrm{C}, \mathrm{CDCl}_{3}, 101 \mathrm{MHz}$

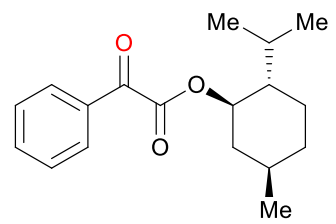

$3 m$

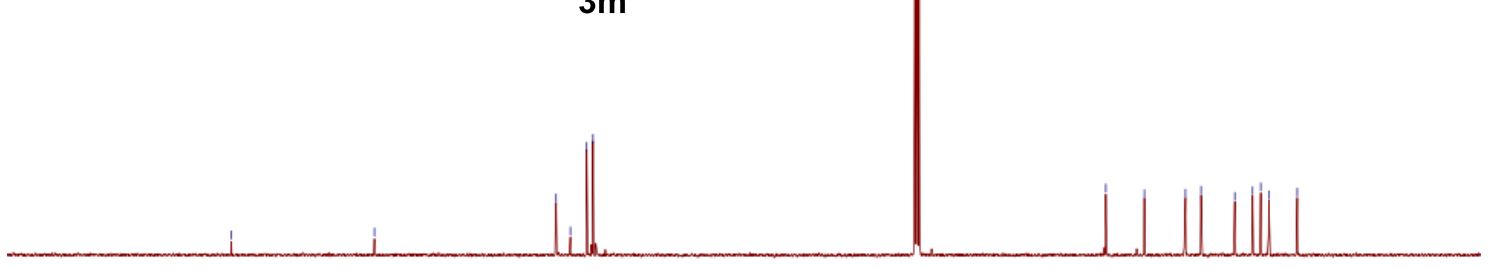

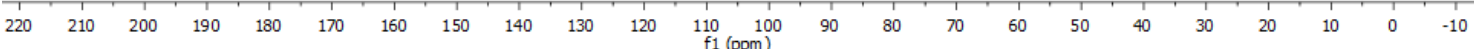


Supplementary Information

10.14. ethyl 2-oxo-2-(thiophen-2-yl)acetate (3n):

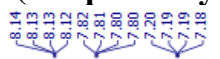

${ }^{1} \mathrm{H}, \mathrm{CDCl}_{3}, 400 \mathrm{MHz}$

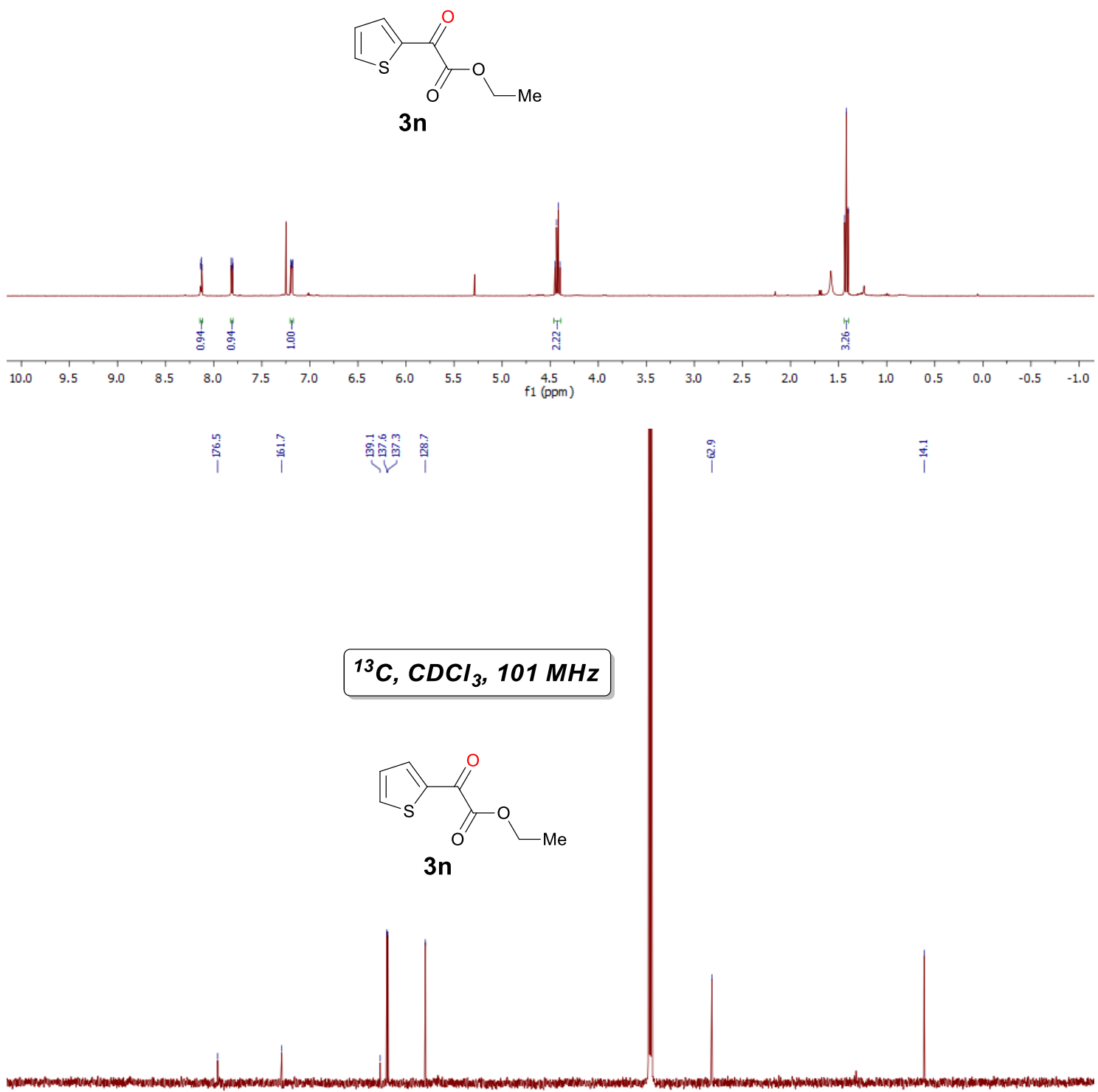

$\begin{array}{lllllllllllllllllllllllll}220 & 210 & 200 & 190 & 180 & 170 & 160 & 150 & 140 & 130 & 120 & 110 & 100 & 90 & 80 & 70 & 60 & 50 & 40 & 30 & 20 & 10 & 0 & -10 & -20\end{array}$ 
Supplementary Information

10.15. tert-butyl 3-(2-methoxy-2-oxoacetyl)-1H-indole-1-carboxylate (3o):

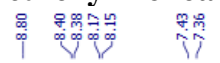
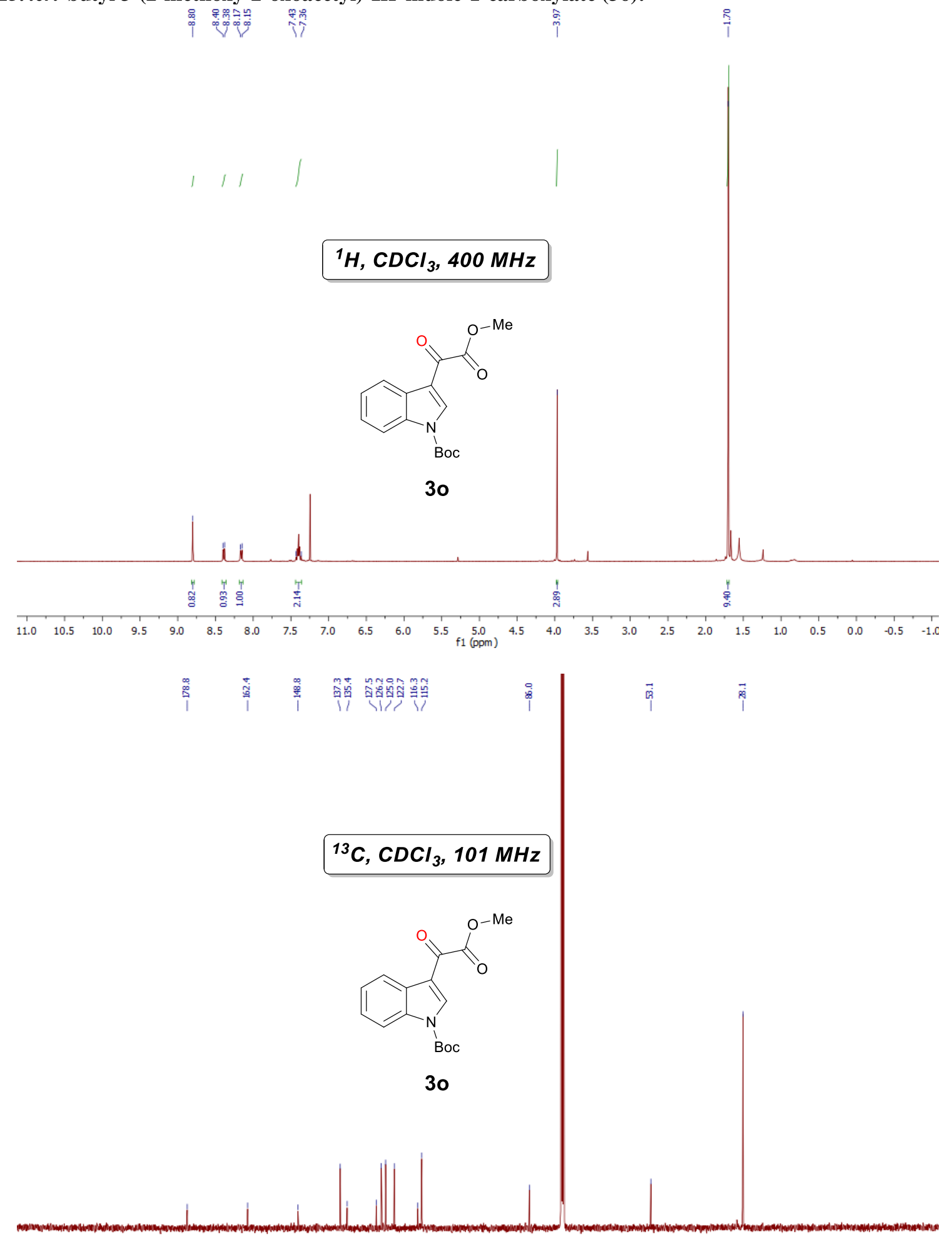

$\begin{array}{lllllllllllllllllllllllll}220 & 210 & 200 & 190 & 180 & 170 & 160 & 150 & 140 & 130 & 120 & 110 & 100 & 90 & 80 & 70 & 60 & 50 & 40 & 30 & 20 & 10 & 0 & -10 & -20\end{array}$ 
Supplementary Information

10.16. ethyl 3-oxo-2,4-diphenyl-1,2-oxazetidine-4-carboxylate (5a):

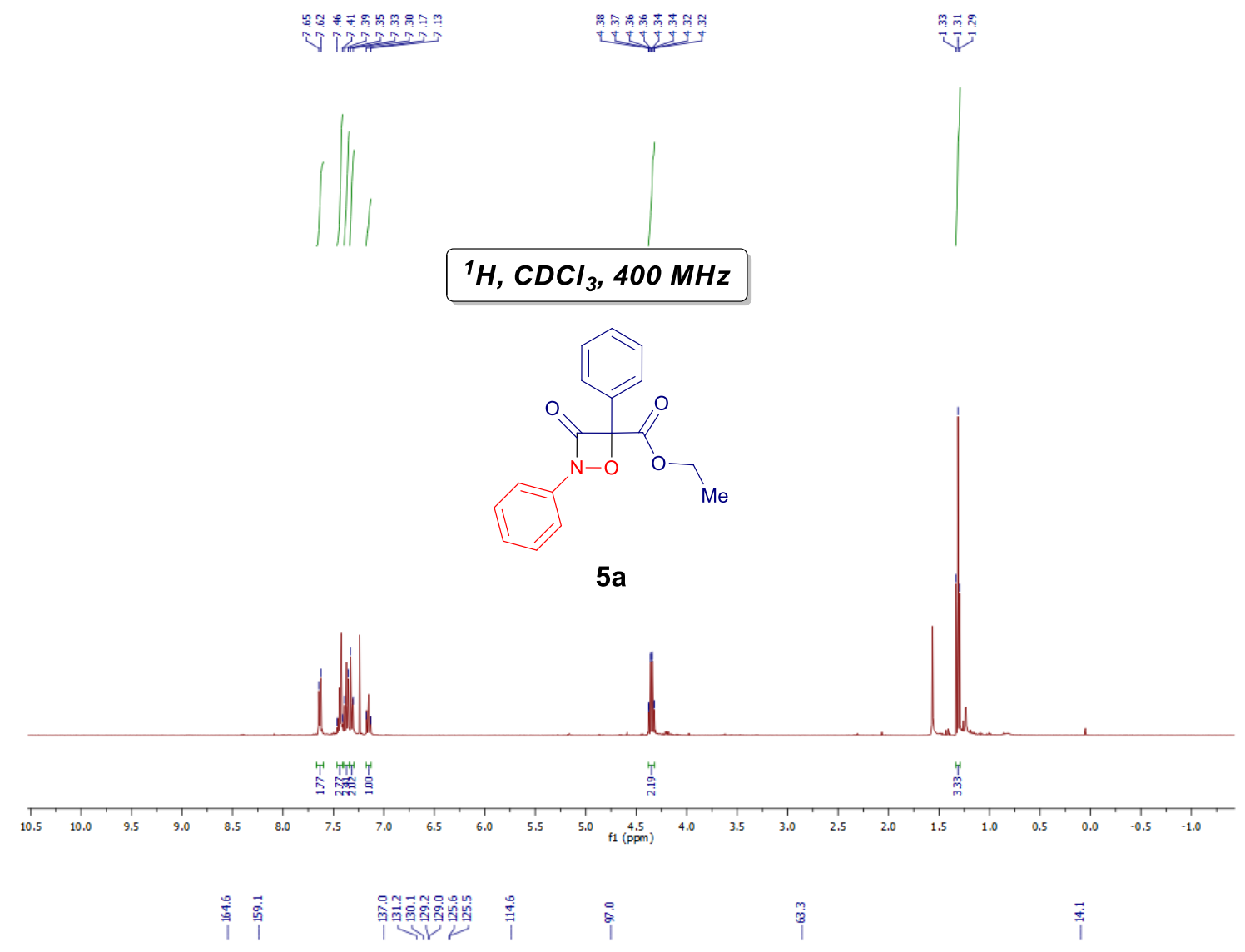

${ }^{13} \mathrm{C}, \mathrm{CDCl}_{3}, 101 \mathrm{MHz}$

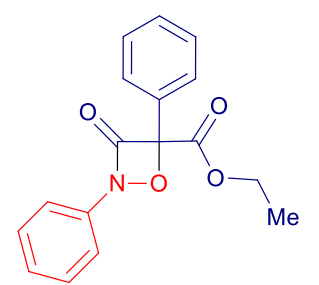

$5 a$

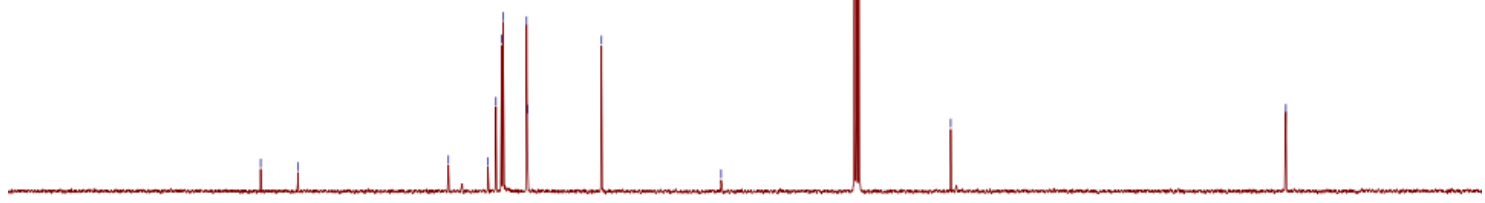

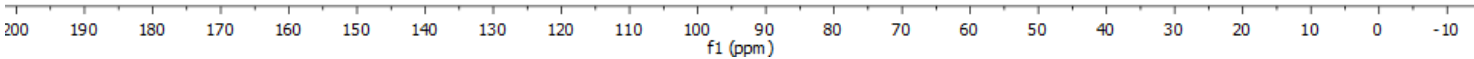


Supplementary Information

10.17. ethyl 3-oxo-2-phenyl-4-(p-tolyl)-1,2-oxazetidine-4-carboxylate (5b):
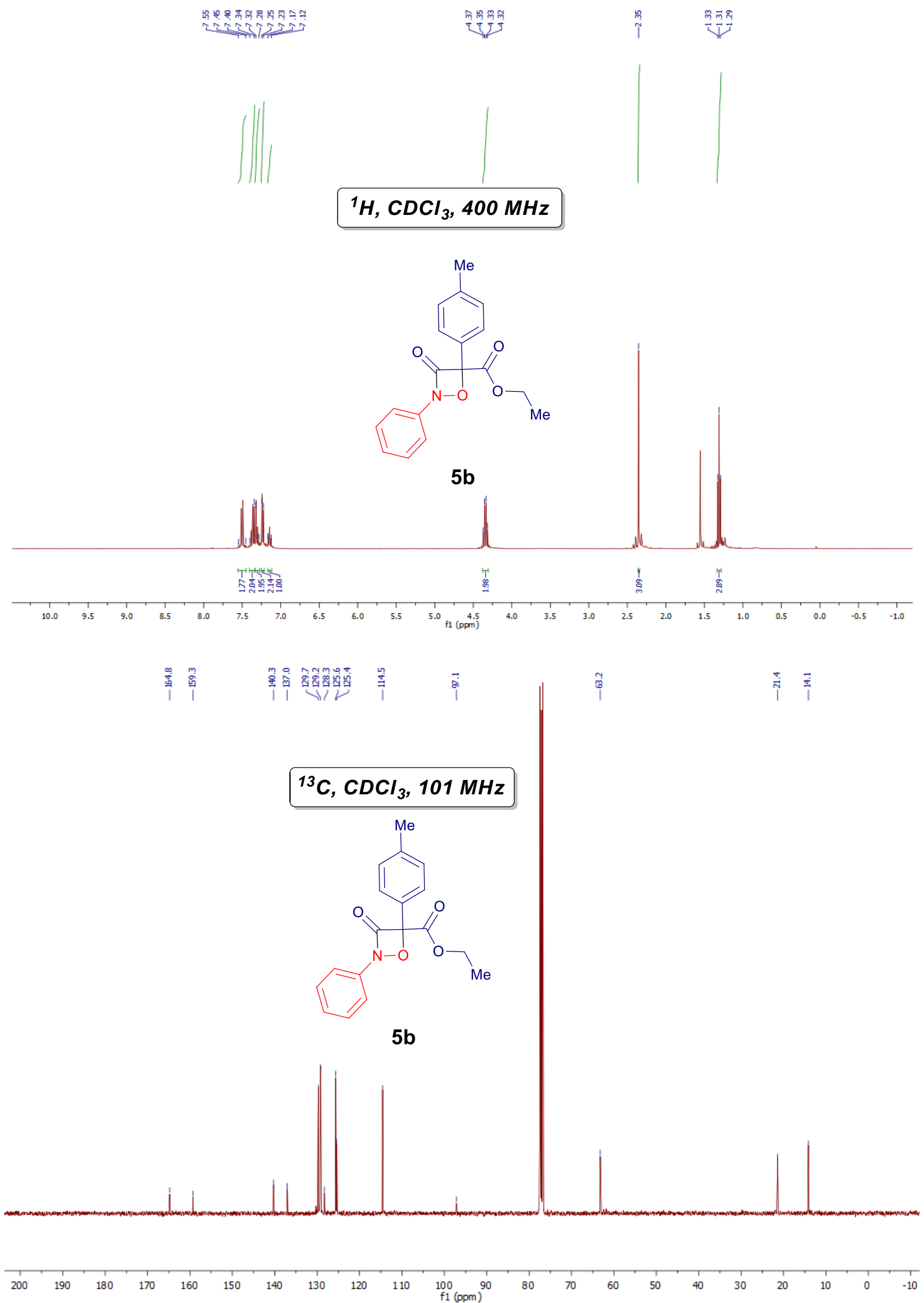
Supplementary Information

10.18. ethyl 4-(4-fluorophenyl)-3-oxo-2-phenyl-1,2-oxazetidine-4-carboxylate (5c):
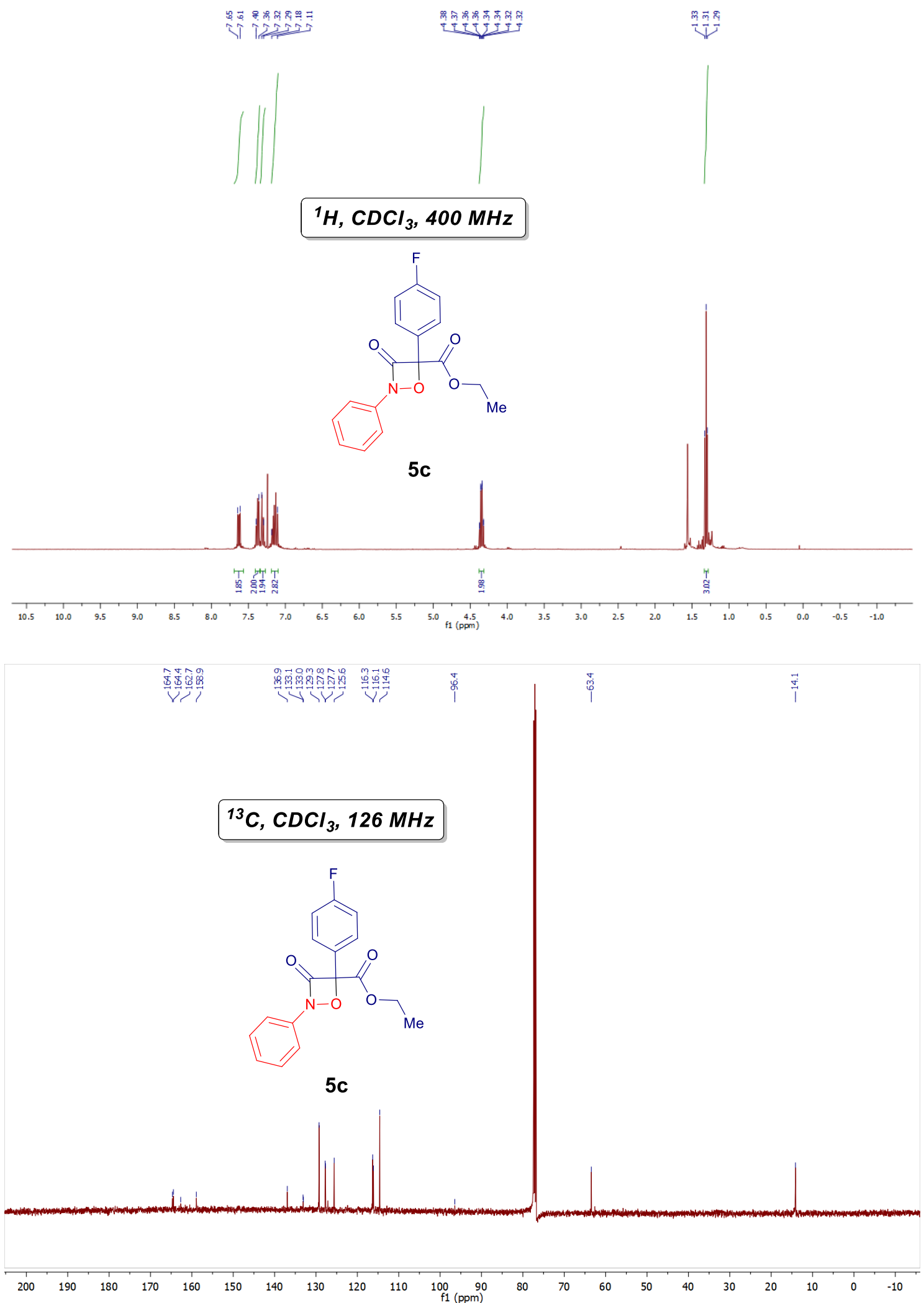
Supplementary Information

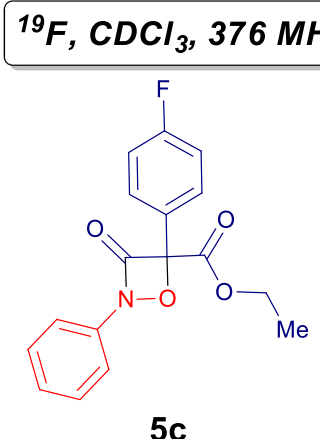

$5 c$

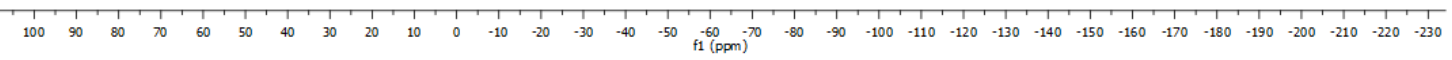


Supplementary Information

10.19. ethyl 4-(4-bromophenyl)-3-oxo-2-phenyl-1,2-oxazetidine-4-carboxylate (5d):

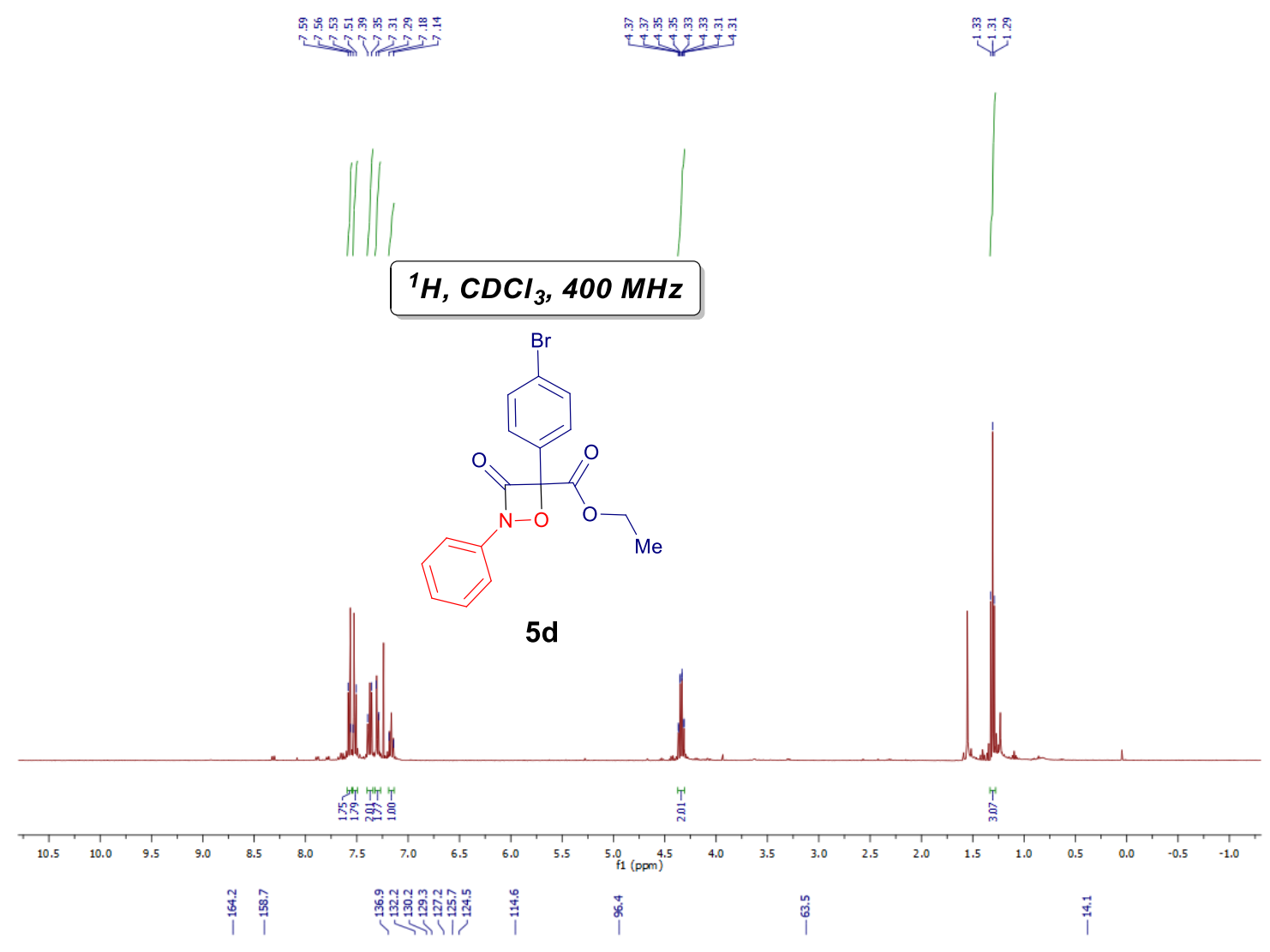

${ }^{13} \mathrm{C} \mathrm{CDCl}_{3}, 101 \mathrm{MHz}$
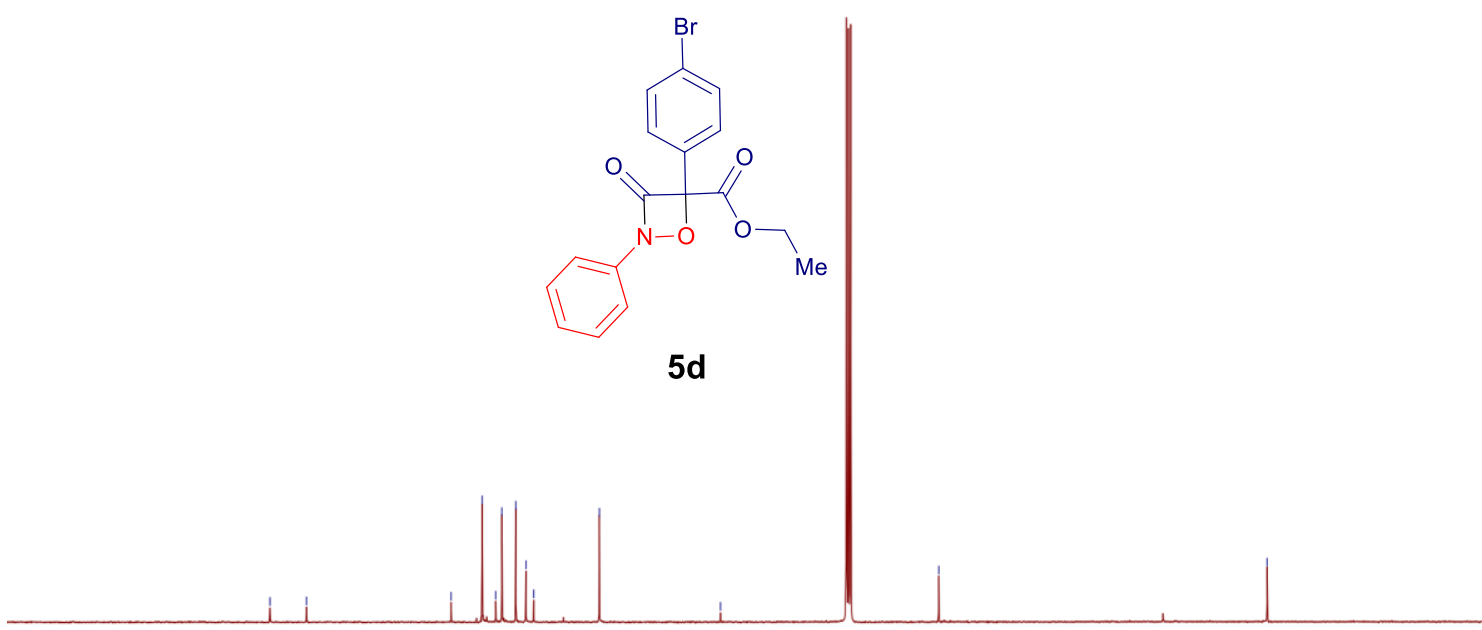

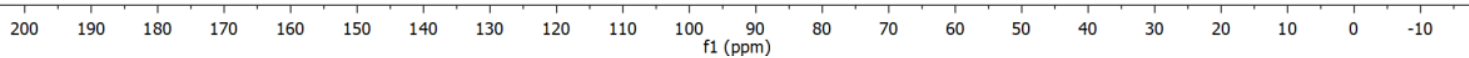


Supplementary Information

10.20. ethyl 3-oxo-4-phenyl-2-(2-(trifluoromethyl)phenyl)-1,2-oxazetidine-4-carboxylate (5e):

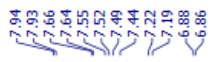

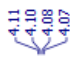
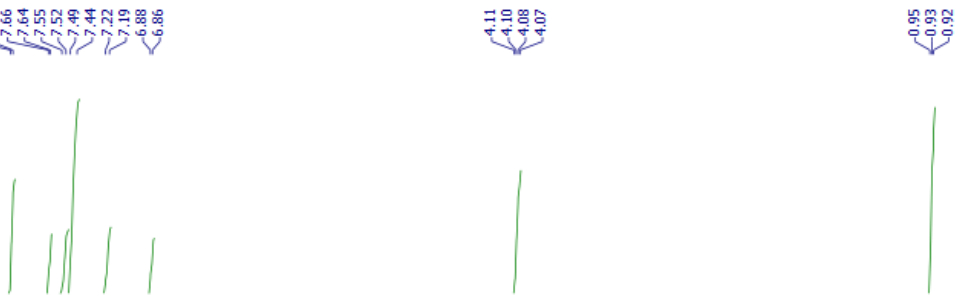

\section{${ }^{1} \mathrm{H}, \mathrm{CDCl}_{3}, 500 \mathrm{MHz}$}
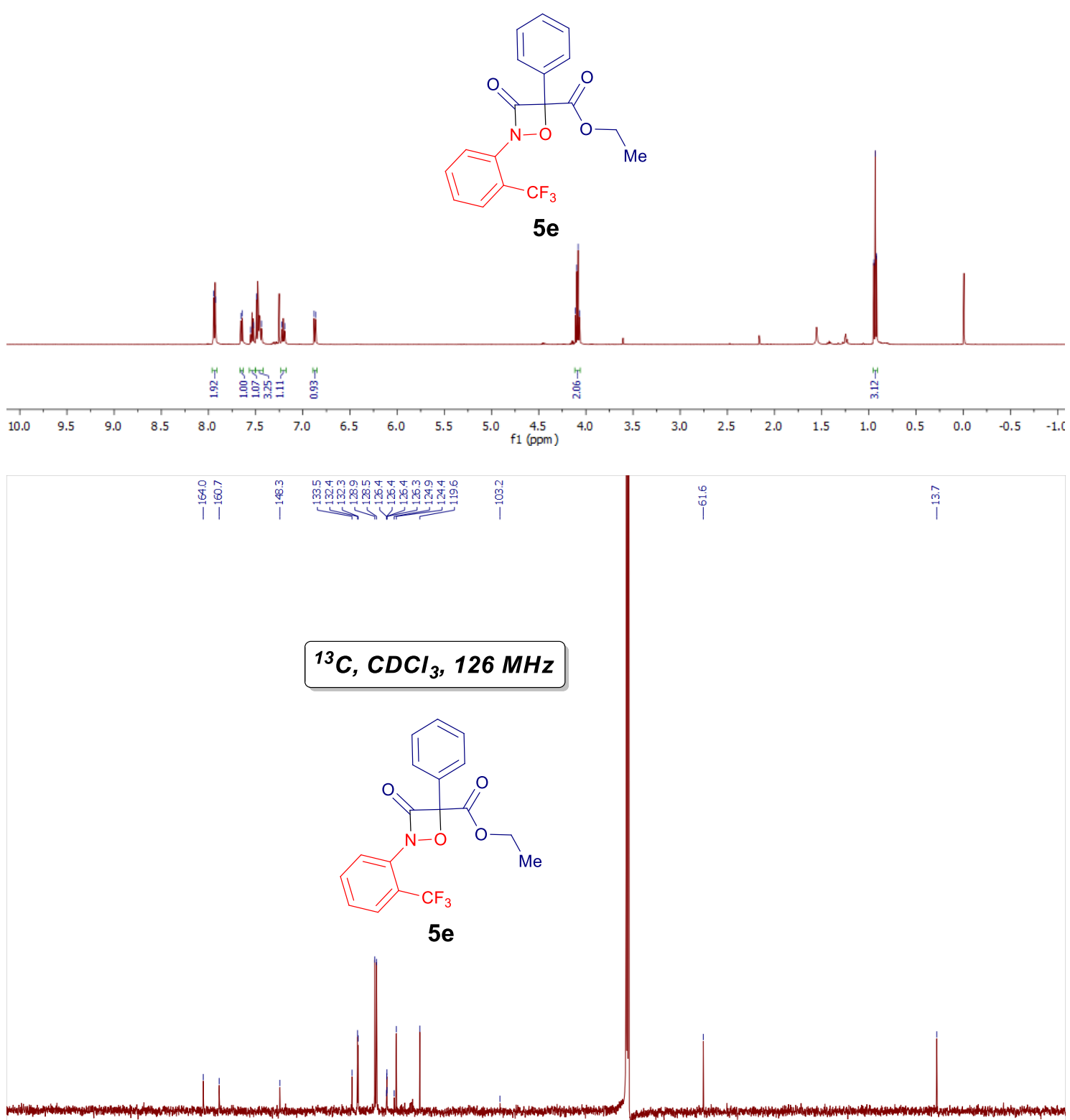
Supplementary Information

${ }^{19} \mathrm{~F}_{\mathrm{CDCl}}, 376 \mathrm{MHz}$

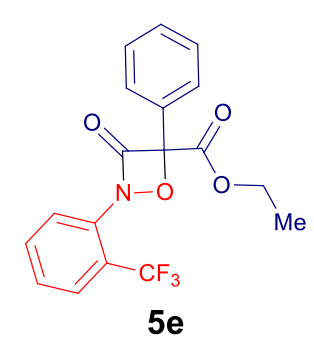

$\begin{array}{llllllllllllllllllllllllllllllllllll}130 & 120 & 110 & 100 & 90 & 80 & 70 & 60 & 50 & 40 & 30 & 20 & 10 & 0 & -10 & -20 & -30 & -40 & -50 & -60 & -70 & -80 & -90 & -100 & -110 & -120 & -130 & -140 & -150 & -160 & -170\end{array}$ 
Supplementary Information

10.21. ethyl 2-(2-cyanophenyl)-3-oxo-4-phenyl-1,2-oxazetidine-4-carboxylate (5f):

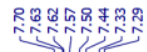

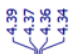

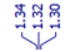
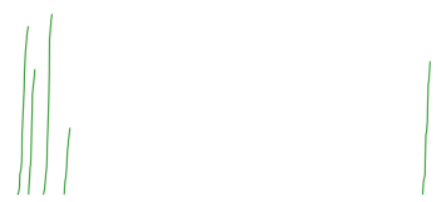

${ }^{1} \mathrm{H}, \mathrm{CDCl}_{3}, 400 \mathrm{MHz}$

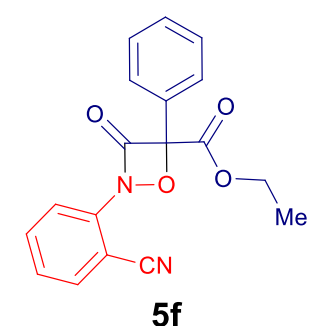

$5 f$
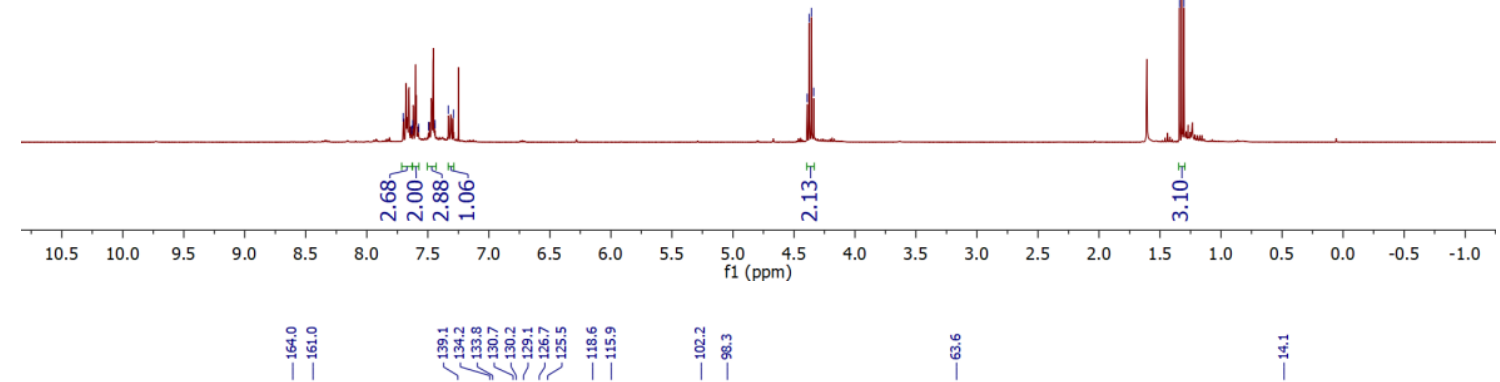

$\stackrel{0}{\grave{6}}$

$\stackrel{\vec{j}}{\mid \overrightarrow{1}}$

\section{${ }^{13} \mathrm{C}, \mathrm{CDCl}_{3}, 101 \mathrm{MHz}$}
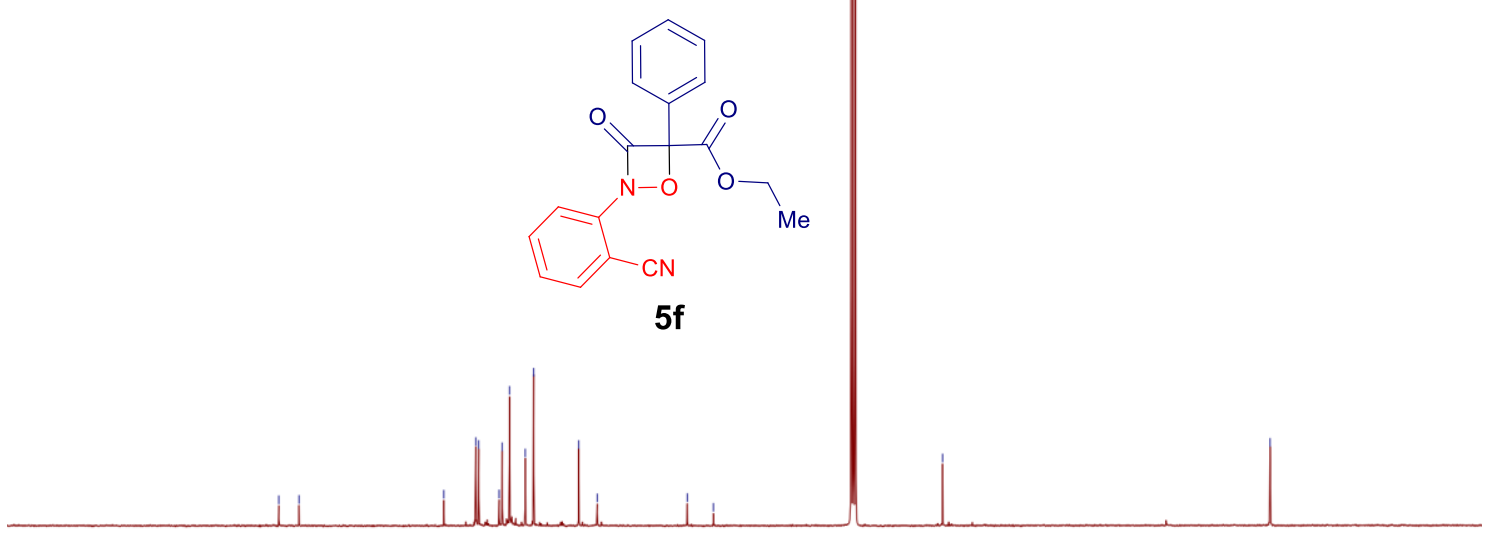

$\begin{array}{lllllllllll}200 & 190 & 180 & 170 & 160 & 150 & 140 & 130 & 120 & 110 & 100 \begin{array}{r}90 \\ \mathrm{f} 1(\mathrm{ppm})\end{array}\end{array}$ 
Supplementary Information

10.22. 2,4-diphenyl-1,2-oxazetidin-3-one (5g):
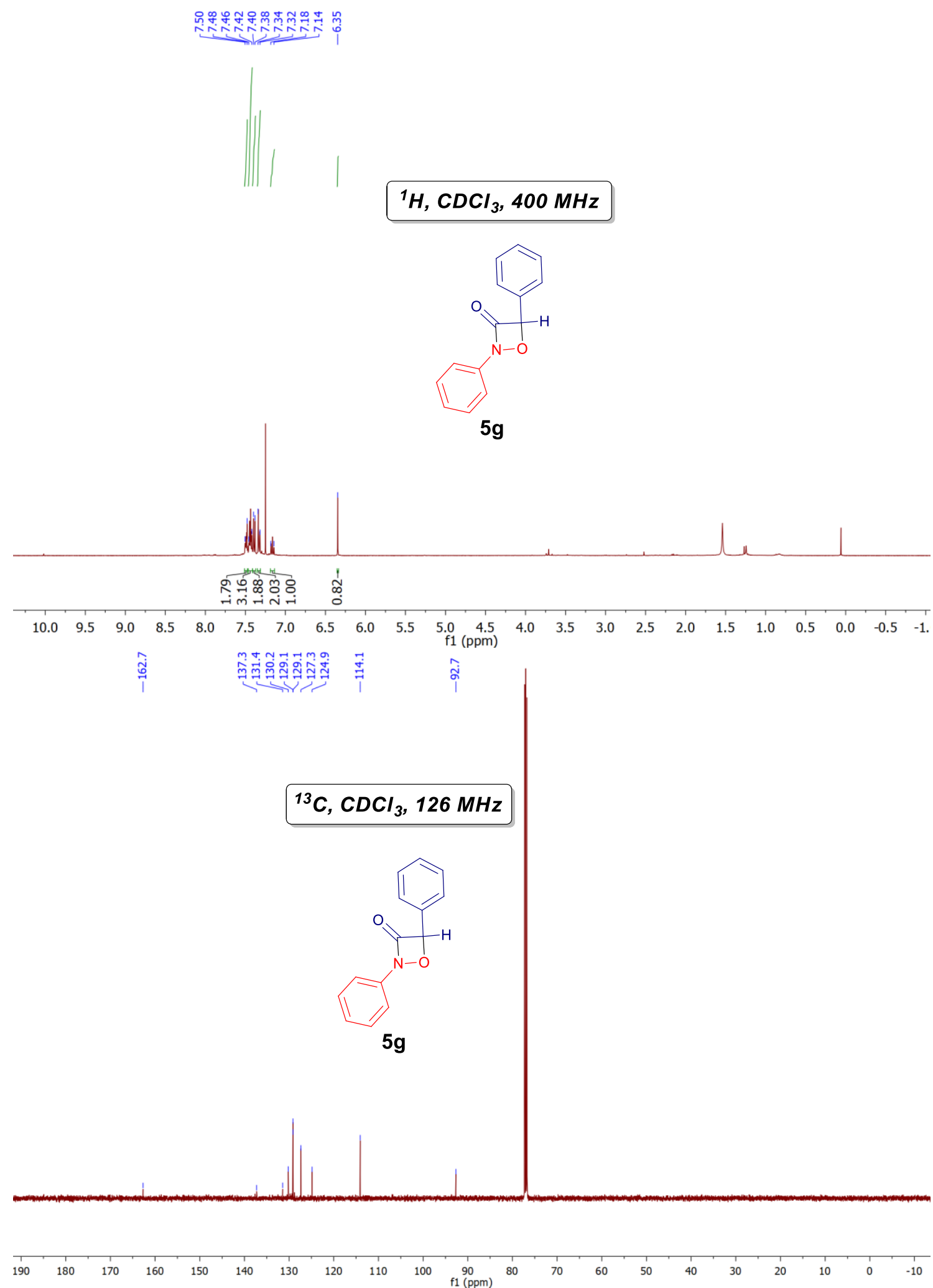
Supplementary Information

10.23. 2-phenyl-4-( $p$-tolyl)-1,2-oxazetidin-3-one (5h):
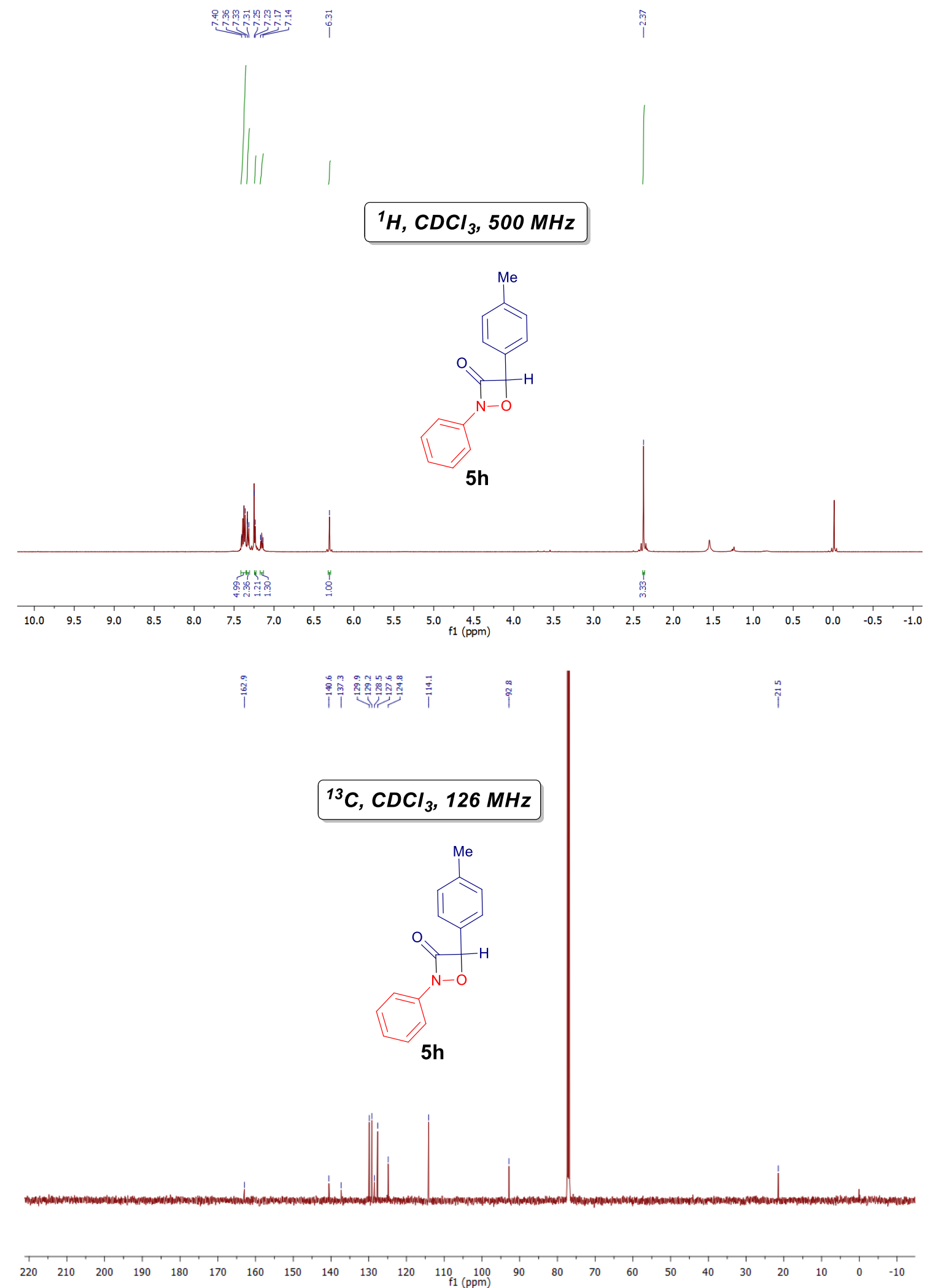
Supplementary Information

10.24. 4-methyl-2,4-diphenyl-1,2-oxazetidin-3-one (5i):
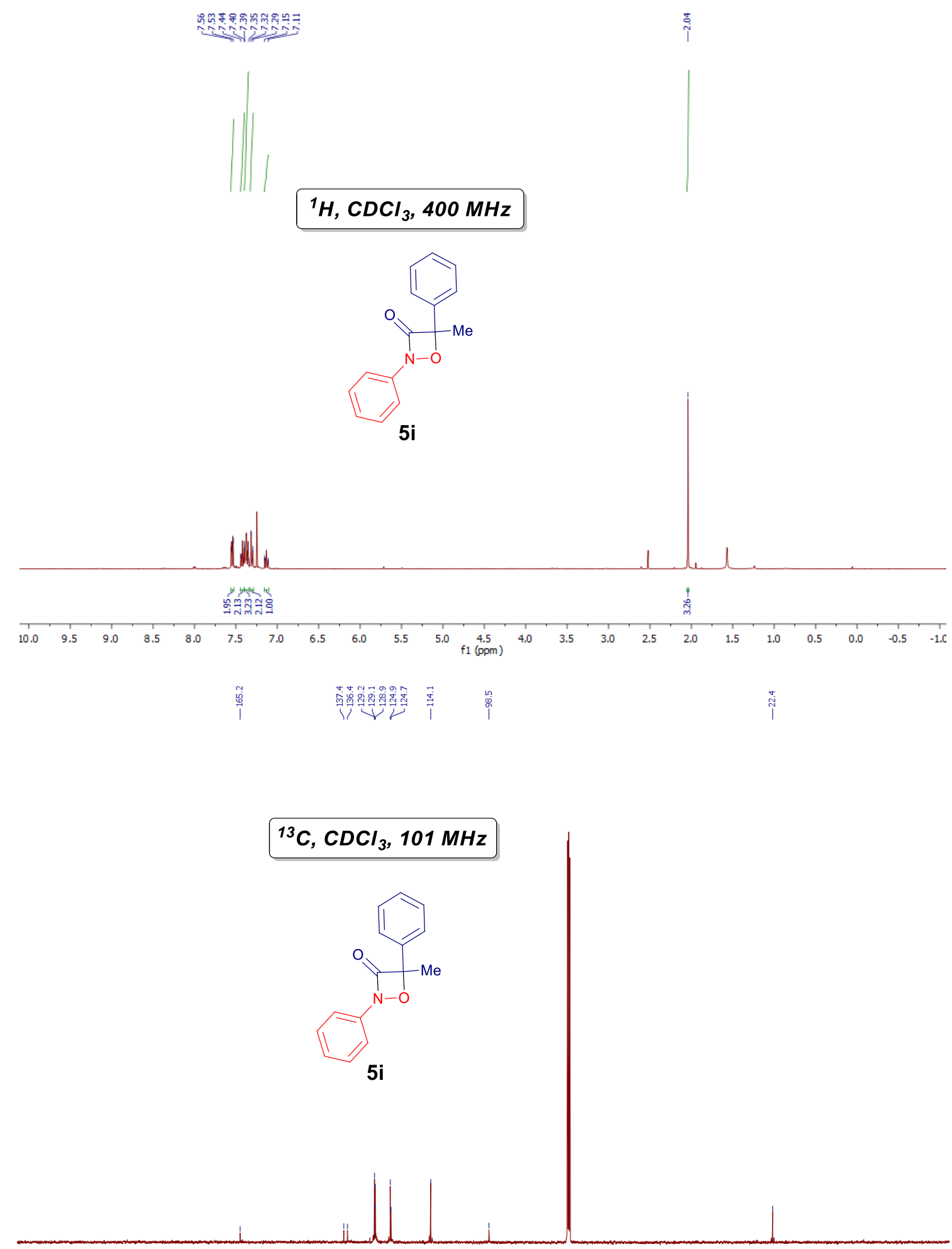

$\begin{array}{lllllllllllllllllllllllllllllllllllllll}220 & 210 & 200 & 190 & 180 & 170 & 160 & 150 & 140 & 130 & 120 & 110 & 100 & 90 & 80 & 70 & 60 & 50 & 40 & 30 & 20 & 10 & 0 & -10 & -20\end{array}$ 
Supplementary Information

10.25. methyl 3-oxo-2-phenyl-4-(thiophen-2-yl)-1,2-oxazetidine-4-carboxylate (5j):

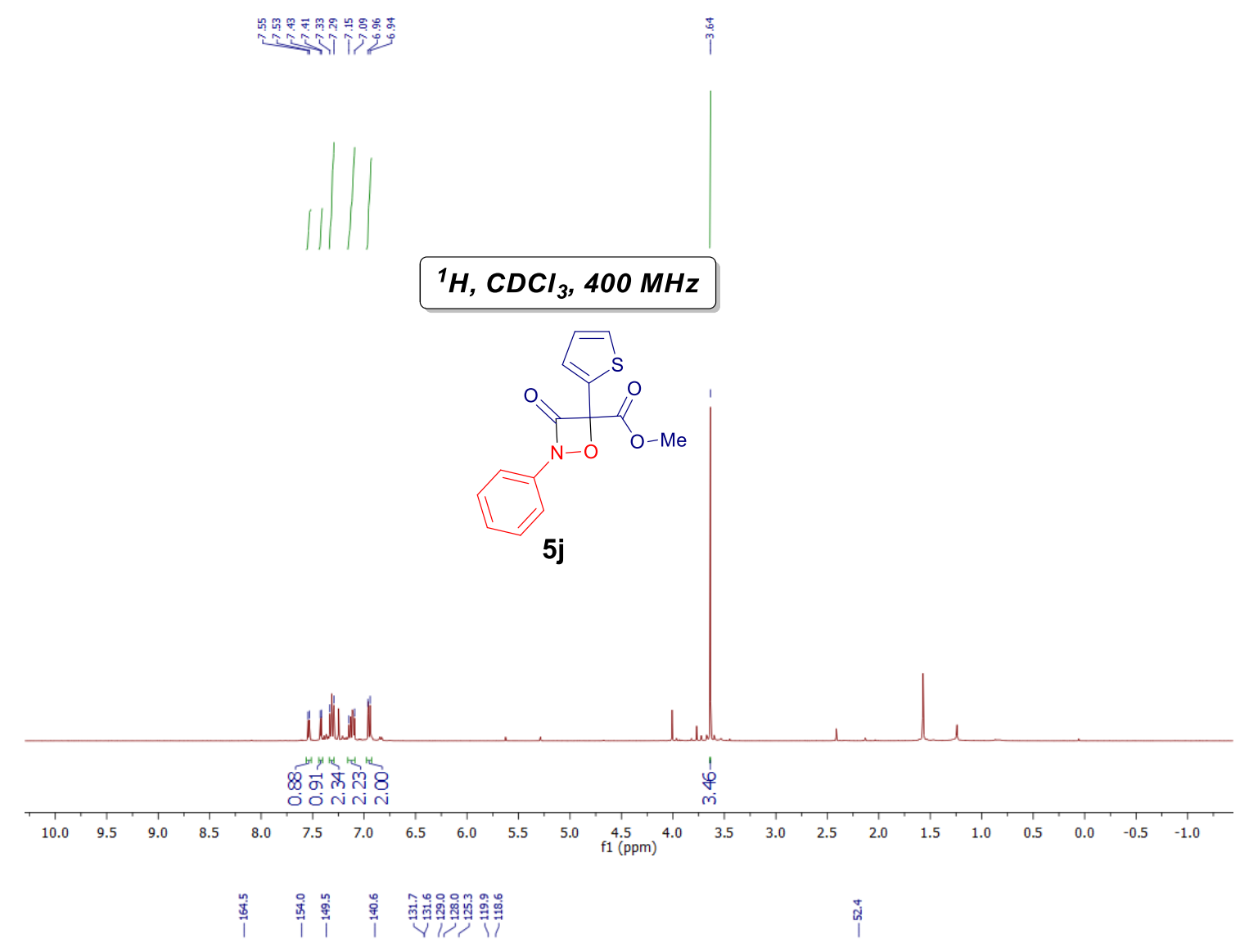

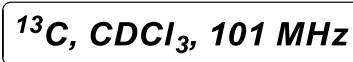

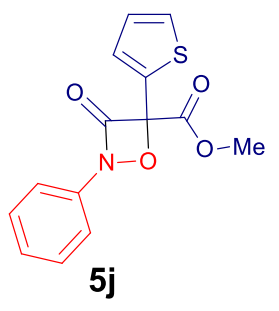

\begin{tabular}{rrrrrrrrrrr}
\hline 200 & 190 & 180 & 170 & 160 & 150 & 140 & 130 & 120 & 110 & 100 \\
$\mathrm{f} 1(\mathrm{ppm})$ & 90
\end{tabular} 
Supplementary Information

10.26. ethyl 3-hydroxy-2-phenyl-2-((phenylamino)oxy)propanoate (6a):

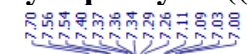

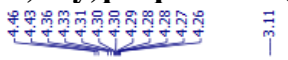
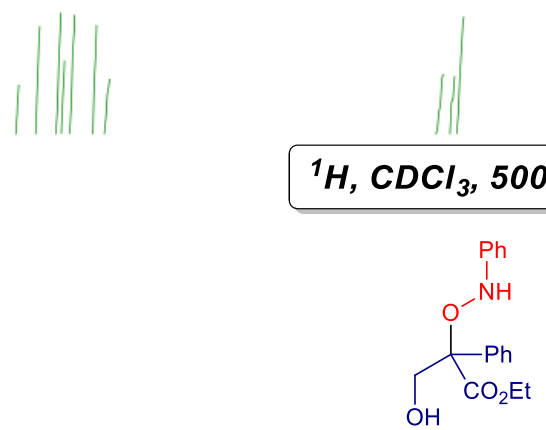

$6 a$

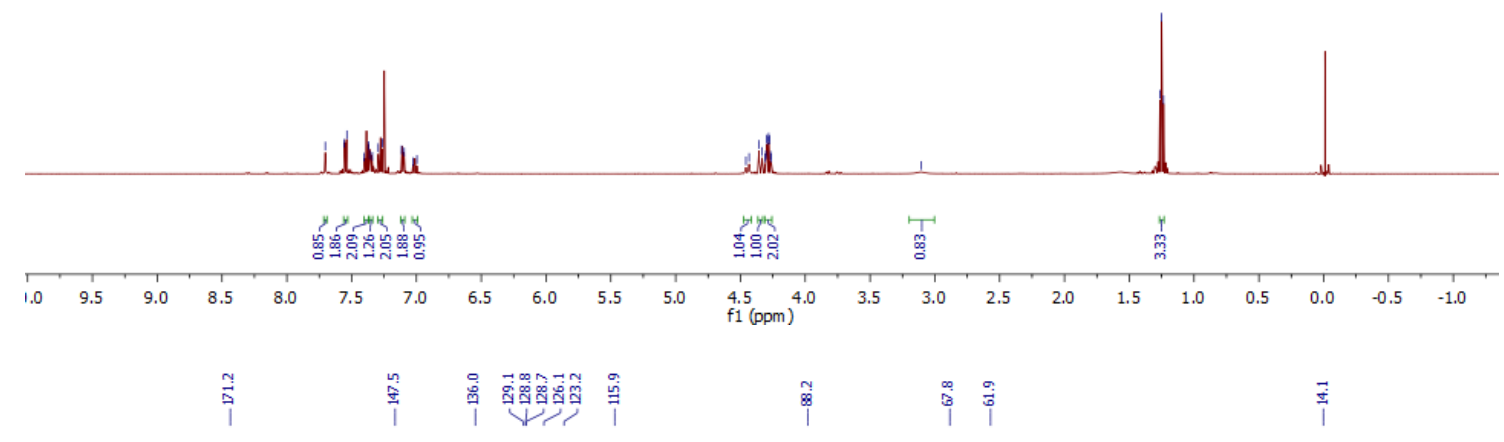

${ }^{13} \mathrm{C}, \mathrm{CDCl}_{3}, 126 \mathrm{MHz}$

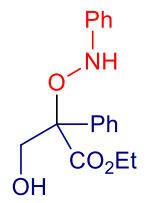

$6 a$
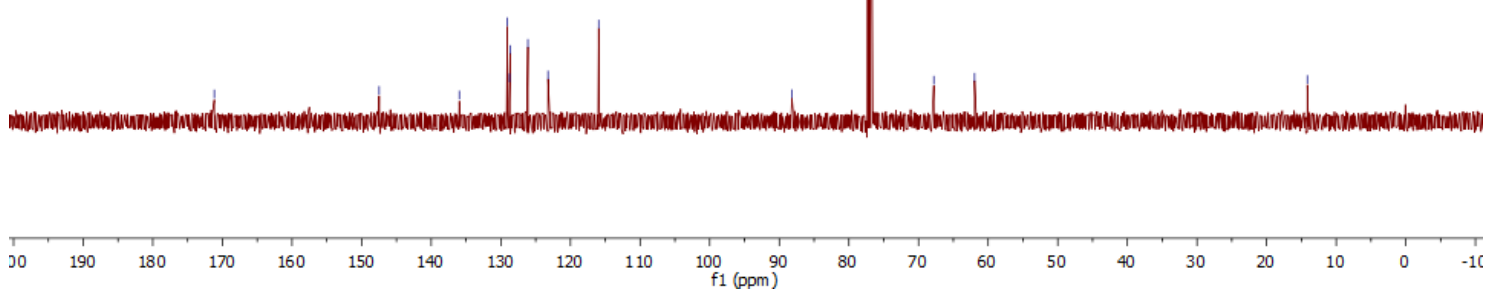
Supplementary Information

10.27. 2-phenyl-2-((phenylamino)oxy)propane-1,3-diol (6b):
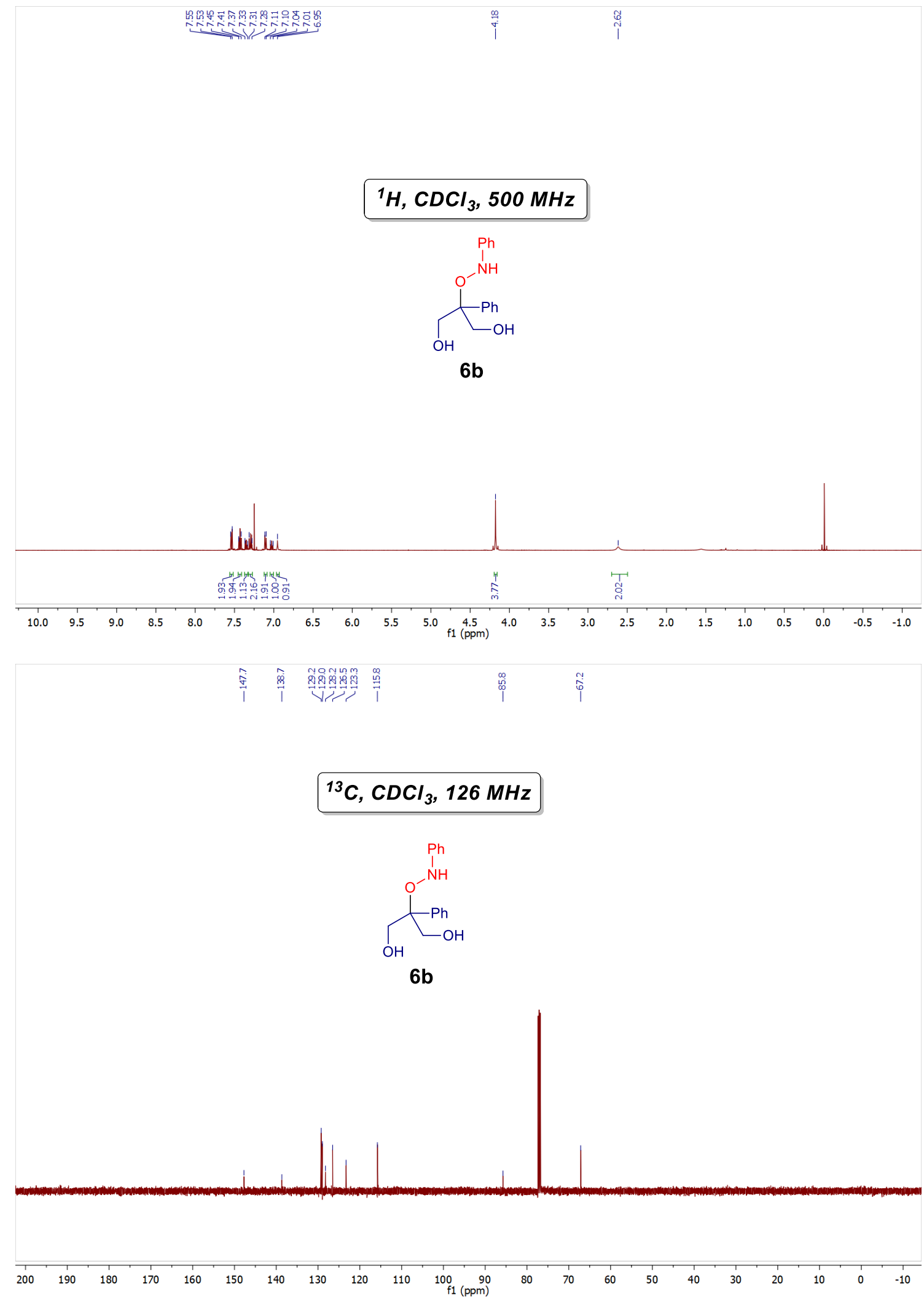
Supplementary Information

10.28. ethyl 2-hydroxy-3-oxo-2-phenyl-3-(phenylamino)propanoate (6c):
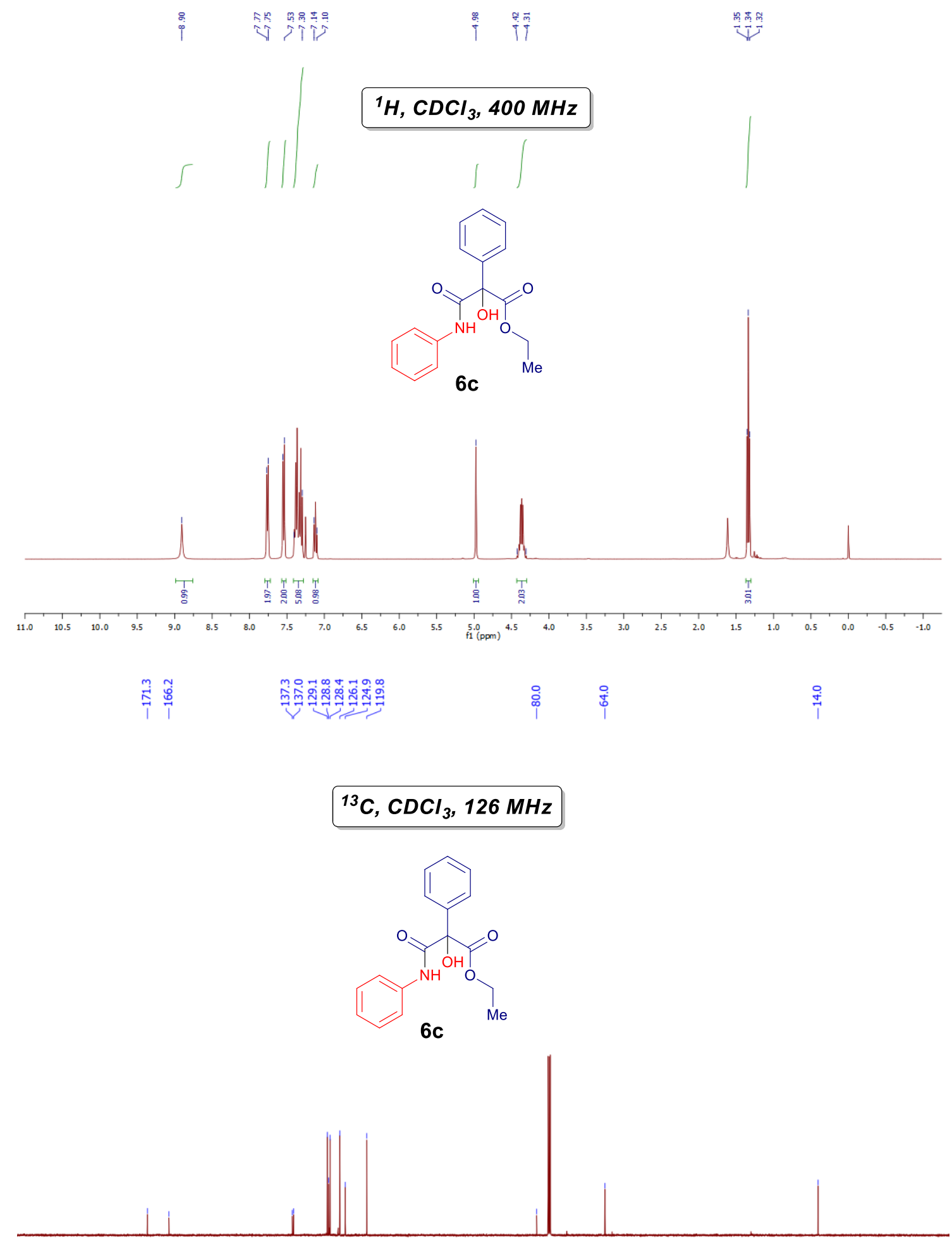